\title{
Hydrogeochemical characterization of springs and wells in the Cacapon Mountain Aquifer
}

\author{
Lacoa L. Corder \\ West Virginia University
}

Follow this and additional works at: https://researchrepository.wvu.edu/etd

\section{Recommended Citation}

Corder, Lacoa L., "Hydrogeochemical characterization of springs and wells in the Cacapon Mountain Aquifer" (2008). Graduate Theses, Dissertations, and Problem Reports. 4363.

https://researchrepository.wvu.edu/etd/4363

This Thesis is protected by copyright and/or related rights. It has been brought to you by the The Research Repository @ WVU with permission from the rights-holder(s). You are free to use this Thesis in any way that is permitted by the copyright and related rights legislation that applies to your use. For other uses you must obtain permission from the rights-holder(s) directly, unless additional rights are indicated by a Creative Commons license in the record and/ or on the work itself. This Thesis has been accepted for inclusion in WVU Graduate Theses, Dissertations, and Problem Reports collection by an authorized administrator of The Research Repository @ WVU. For more information, please contact researchrepository@mail.wvu.edu. 


\title{
Hydrogeochemical Characterization of Springs and Wells in the Cacapon Mountain Aquifer
}

\author{
Lacoa L. Corder \\ Thesis submitted to the \\ Eberly College of Arts and Sciences at \\ West Virginia University \\ in partial fulfillment of the requirements \\ for the degree of \\ Master of Science \\ in \\ Geology \\ Dorothy J. Vesper, Ph.D., Chair \\ Joseph J. Donovan, Ph.D. \\ Eberhard Werner, M.S. \\ Department of Geology and Geography \\ Morgantown, West Virginia \\ 2008
}

Keywords: hydrogeology, carbonate, Berkeley Springs, Morgan County, geochemistry 


\author{
ABSTRACT \\ Hydrogeochemical Characterization of Springs and Wells \\ in the Cacapon Mountain Aquifer
}

Lacoa L. Corder

The Cacapon Mountain Aquifer is located near Berkeley Springs in Morgan County, West Virginia. Approximately 120 wells were selected for a synoptic survey of data including static water levels, pHs, specific conductances, and temperatures to assess regional hydrogeology and geochemistry. Six springs and four wells were sampled on a monthly basis to identify their hydrochemical types and infer the geology of their recharge areas. The potentiometric surface obtained at wells was found to be a subdued reflection of topography. The geologic structure was determined to generally control the direction of ground water flow. Ground water was transmitted in a cross-strike direction on the slopes and in an along-strike direction in Cold Run Valley, parallel to the trend of Cacapon Mountain. Springs could be categorized into two hydrochemical groups; reflecting either a carbonate or siliceous source. Although water from Ladies' Spring was much warmer than all other springs, it was chemically very similar to the carbonate-derived spring waters. 


\section{ACKNOWLEDGEMENTS}

I would first like to thank the people who made this research possible, the Morgan County Rural Water Committee and the West Virginia Conservation Agency. These groups supported my research and were a pleasure to work with as they are so curious and passionate about their water resources, locally and beyond.

Much thanks to Mary Banks-Nichols, who let me stay in her beautiful home and enjoy her company. I will always miss our talks, her worldly cooking, and the care she bestows upon her friends, flowers, and family.

This project would not have been near as successful or fun if I had not had such a fantastic summer field assistant. Thank you Maxie Maggio for your energy and positive attitude. I wish you the best of luck in all your adventures and know that you will be brilliant in whatever field you choose.

Thank you to all of the well and spring owners in Morgan County who participated in this research. You often welcomed me into your homes and lives, and I am grateful to have had a home away from home in your community. I will especially miss my monthly visits as I got to know you better and we became friends.

My committee members, Dorothy Vesper (chair), Joe Donovan, and Eb Werner, have been positive and helpful throughout this long journey. It would have been impossible for me to complete this research without their insight. Thank you for always encouraging and pushing me to do better, faster. I especially appreciate all of their personal stories, which I have taken to heart, and tried to incorporate into my life and work. Thank you Dorothy for being a friend and keeping things realistic. I strive to be the teacher you are in all facets of life.

Finally, thanks to my friends and family who have always supported me and encouraged me to just get "er" done. And, thank you to all of my incredible professors at WVU who have gotten me to where I am today and have made me love this field. 


\section{TABLE OF CONTENTS}

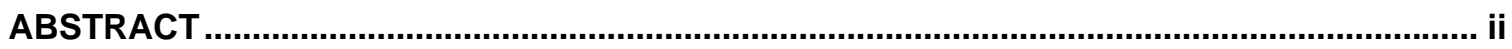

ACKNOWLEDGEMENTS ................................................................................................ ii

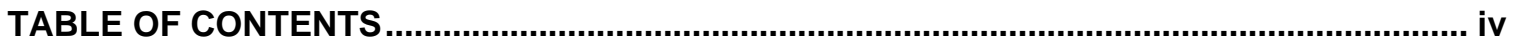

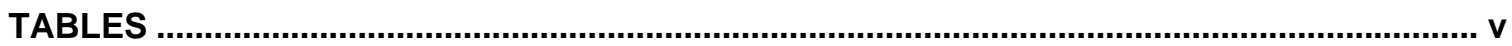

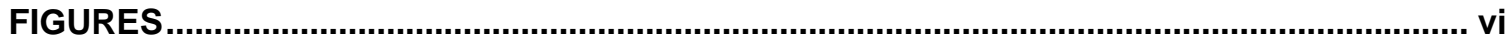

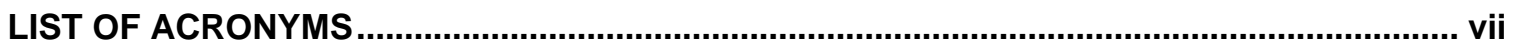

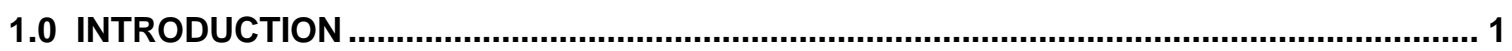

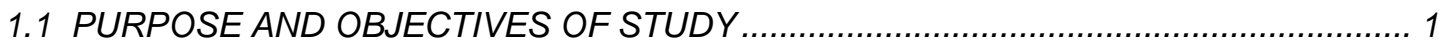

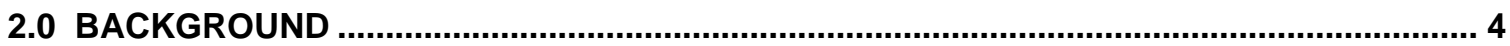

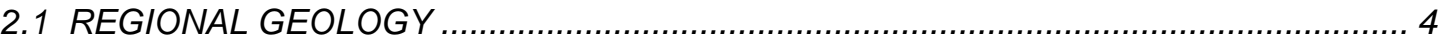

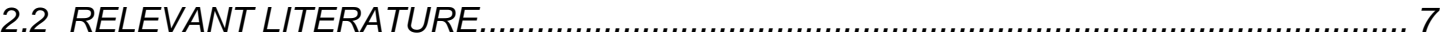

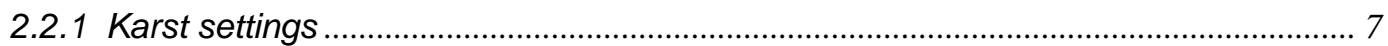

2.2.2 Structural controls on ground water flow.................................................................... 9

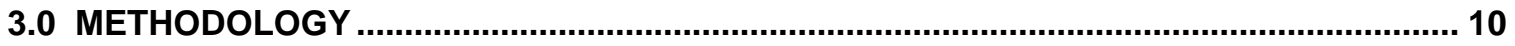

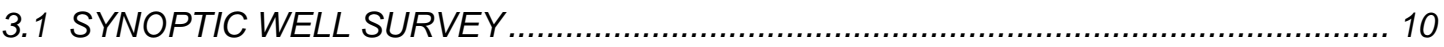

3.1.1 Site selection ...................................................................................................................... 10

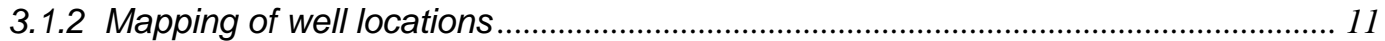

3.1.3 Static water level (SWL) measurement................................................................... 11

3.1.4 Chemical screening data measurements ............................................................... 11

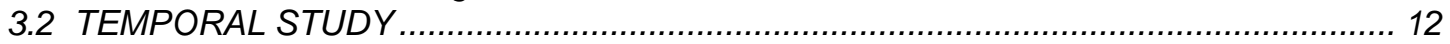

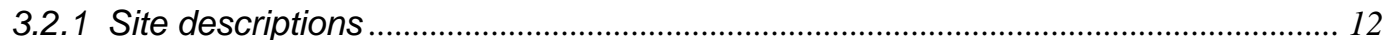

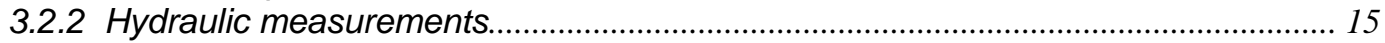

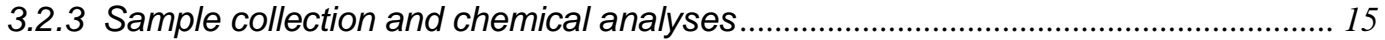

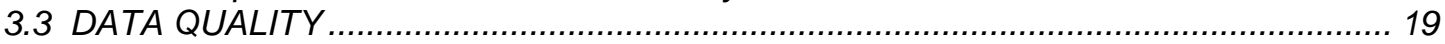

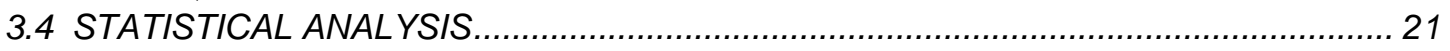

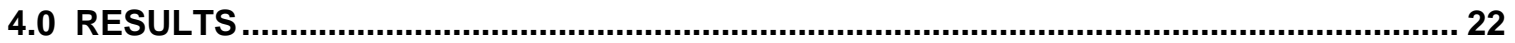

4.1 SYNOPTIC SURVEY CHEMICAL DATA AND WATER LEVEL DATA .......................... 22

4.2 TEMPORAL STUDY CHEMICAL DATA AND WATER LEVEL DATA ......................... 22

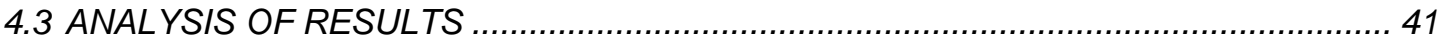

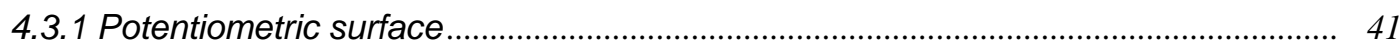

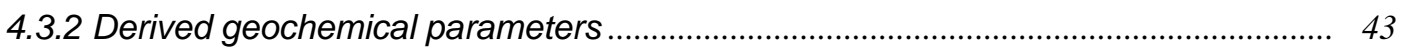

4.3.3 Relationships between chemical parameters.......................................................... 50

4.3.4 Comparison of well and spring data ......................................................................... 54

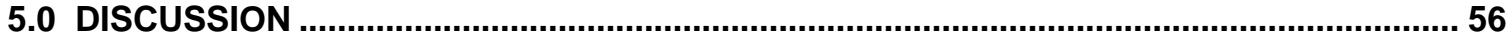

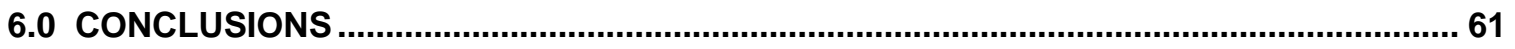

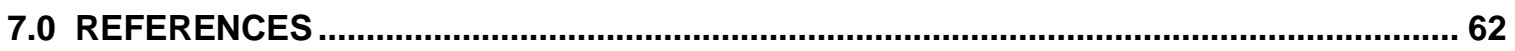

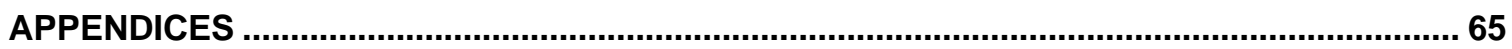




\section{TABLES}

Table 1: Coordinates, ID, sample type, and geology at selected springs and wells...... 13

Table 2: Number and timing of water samples at selected locations................... 16

Table 3: Summary of analytical methods and sample collection and preservation........ 18

Table 4: Summary of three PCAs................................................... 51

Table 5: Spring groups by chemistry, location, and speculative source....................... 57

\section{APPENDIX TABLES}

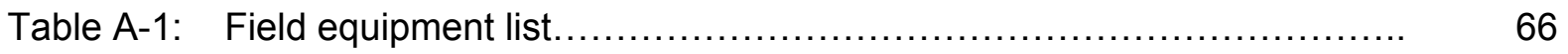

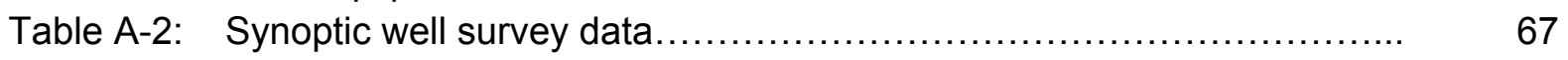

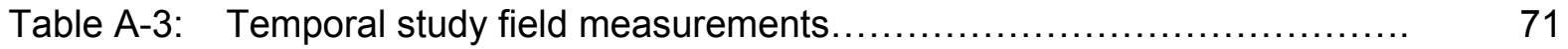

Table A-4: Daily temperature measurements at Berkeley Springs $3 \mathrm{~S}$ weather

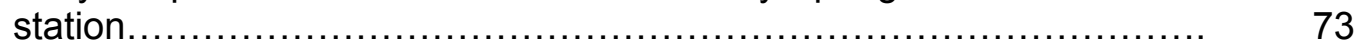

Table A-5: Daily rainfall measurements at Berkeley Springs $3 \mathrm{~S}$ weather

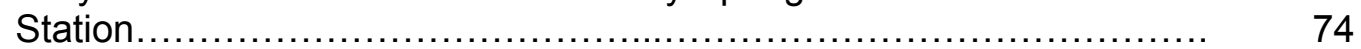

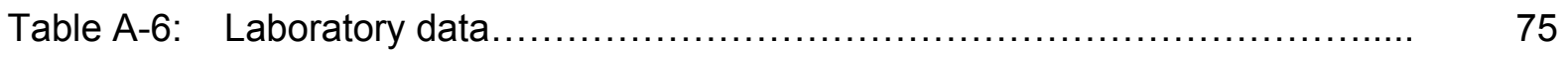

Table A-7: $\quad$ Mean and coefficient of variation for selected parameters at study

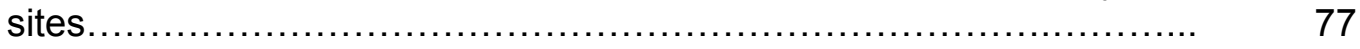

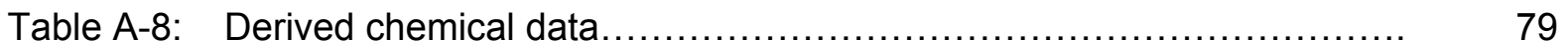




\section{FIGURES}

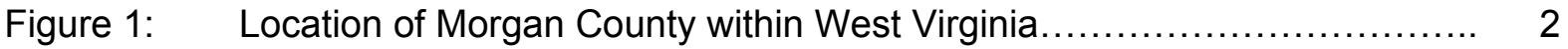

Figure 2: $\quad$ Springs and wells selected for temporal survey .......................... 3

Figure 3: $\quad$ Cross section of Cacapon Mountain anticline- Grimsley and White (1916) 5

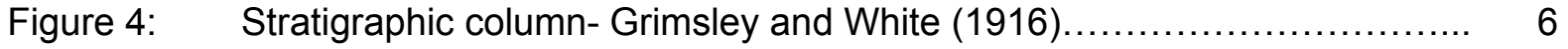

Figure 5: $\quad$ Regional distribution of $\mathrm{SC}(\mu \mathrm{S} / \mathrm{cm})$ in study area........................... 23

Figure 6: $\quad$ Regional distribution of $\mathrm{pH}$ at wells in study area.......................... 24

Figure 7: $\quad$ Potentiometric surface- Donovan JJ, Werner E, Vesper DJ, Corder L 25 (2006).

Figure 8: $\quad$ Chemical parameters, stage, and rainfall through time at LDY (Spring).... 27

Figure 9: $\quad$ Chemical parameters, stage, and rainfall through time at NEY (Spring)... 28

Figure 10: Chemical parameters, stage, and rainfall through time at WEB (Spring)... 29

Figure 11: $\quad$ Chemical parameters, stage, and rainfall through time at CSP (Spring)... 30

Figure 12: $\quad$ Chemical parameters, stage, flow, and rainfall through time at MTN 31

(Spring).....

Figure 13: $\quad$ Chemical parameters, flow, and rainfall through time at $\mathrm{HGH}$ (Spring)..... 32

Figure 14: Chemical parameters and rainfall through time at STR (Well) ............... 33

Figure 15: $\quad$ Chemical parameters, stage, and rainfall through time at MYR (Well)....... 34

Figure 16: Chemical parameters, stage, and rainfall through time at BZK (Well)...... 35

Figure 17: $\quad$ Chemical parameters, stage, and rainfall through time at YST (Well)...... 36

Figure 18: Temperature differences among sites....................................... 37

Figure 19(a): pH vs. SC (b): SC vs. alkalinity at all locations .......................... 38

Figure 20: $\quad$ Box and whisker plots of silicon concentration at all sites.................. 39

Figure 21: $\quad$ Piper diagram of all wells and springs in temporal study .................... 40

Figure 22: $\quad$ Static water level through time for wells in the temporal study............. 42

Figure 23: Box and whisker plots of the calcium to magnesium molar ratio at all sites 44

Figure 24: Enhanced $\mathrm{P}_{\mathrm{CO} 2}$ vs. $\mathrm{pH}$ at all locations but siliceous springs................. 46

Figure 25: $\quad$ Calcium to magnesium molar ratio vs. enhanced $\mathrm{P}_{\mathrm{CO} 2} \ldots \ldots \ldots \ldots \ldots \ldots \ldots \ldots . . \ldots \ldots$

Figure 26: $\quad$ Box and whisker plots of the calcite saturation index at all sites............. 49

Figure 27: $\quad$ PC1 scores vs. Ca concentration for all locations........................ 52

Figure 28: $\quad$ PC1 scores vs. PC2 scores for all locations............................ 53 


\section{LIST OF ACRONYMS}

\begin{tabular}{|c|c|}
\hline ATC & Automatic temperature compensation \\
\hline BDL & Below detection limit \\
\hline $\mathrm{Ca}$ & Calcium \\
\hline $\mathrm{Ca} / \mathrm{Mg}$ & Calcium to magnesium molar ratio \\
\hline CBE & Charge balance error \\
\hline CFC & Chlorofluorocarbon \\
\hline $\mathrm{Cl}$ & Chloride \\
\hline COV & Coefficient of variation \\
\hline DI & Deionized water \\
\hline DRG & Digital raster graphics \\
\hline EPA & Environmental Protection Agency \\
\hline $\mathrm{Fe}$ & Iron \\
\hline GPS & Global positioning system \\
\hline $\mathrm{HCO}_{3}$ & Unit for reporting alkalinity \\
\hline I & Ionic strength \\
\hline IC & Ion chromatography \\
\hline ICP-OES & $\begin{array}{l}\text { Inductively coupled plasma-optical } \\
\text { emission spectroscopy }\end{array}$ \\
\hline IQR & Interquartile range \\
\hline K & Potassium \\
\hline $\mathrm{Mg}$ & Magnesium \\
\hline $\mathrm{Mn}$ & Manganese \\
\hline MCL & Maximum contaminant level \\
\hline $\mathrm{Na}$ & Sodium \\
\hline NAD83 & North American datum of 1983 \\
\hline $\mathrm{NO}_{3}$ & Nitrate \\
\hline PCA & Principal component analysis \\
\hline $\mathrm{P}_{\mathrm{CO} 2}$ & Partial pressure of carbon dioxide \\
\hline$P_{\text {CO2ATM }}$ & Partial pressure of atmospheric carbon dioxide \\
\hline QA & Quality assurance \\
\hline $\mathrm{Si}$ & Silicon \\
\hline $\mathrm{SI}_{\mathrm{C}}$ & Saturation index of calcite \\
\hline$S I_{D}$ & Saturation index of dolomite \\
\hline $\mathrm{SI}_{\mathrm{Q}}$ & Saturation index of quartz \\
\hline SC & Specific conductance \\
\hline $\mathrm{SO}_{4}$ & Sulfate \\
\hline SWL & Static water level \\
\hline $\mathrm{T}$ & Temperature \\
\hline T.U. & Tritium units \\
\hline USGS & United States Geological Survey \\
\hline
\end{tabular}




\subsection{INTRODUCTION}

At the turn of the 21st century, springs supplying water to the towns of Berkeley Springs and Bath in Morgan County, West Virginia (Figure 1) declined in productivity to collectively yield a record low of $2.8 \mathrm{~m}^{3} / \mathrm{min}$ (750 gal $/ \mathrm{min}$ ) (Berkeley Springs 2006). This discharge, which was approximately half of the spring's normal output (Hobba et al. 1977), was attributed to a statewide drought that occurred roughly from 1999 to 2002 . Concerns mounted over the springs' ability to sustain Morgan County's growing population and have since spurred residents to learn more about the sustainability of their water supply. A detailed hydrogeologic investigation was conducted to address this matter.

Berkeley Springs is significant from both an historical and scientific standpoint. The springs' waters were once used by Native Americans and other visitors and are now used as a public water supply for the Town of Bath (Berkeley Springs 2006).

\subsection{PURPOSE AND OBJECTIVES OF STUDY}

Little research has been conducted on ground water drainage and recharge patterns in Morgan County, West Virginia. Consequently, the overall purpose of this research was to characterize the regional hydrogeologic setting. The specific objectives were to:

- Identify and map springs in diverse topographical and hydrogeologic settings;

- Construct a potentiometric map and interpret ground water flow directions; and,

- Analyze spring and well water for major ion chemistry to determine hydrochemical facies and interpret sources and flow directions.

The study area extends eastward from Cacapon Mountain to the Route 522 corridor and south from the Potomac River in Morgan County to the local fish hatchery at Ridge, south of Cacapon State Park (Figure 2). 


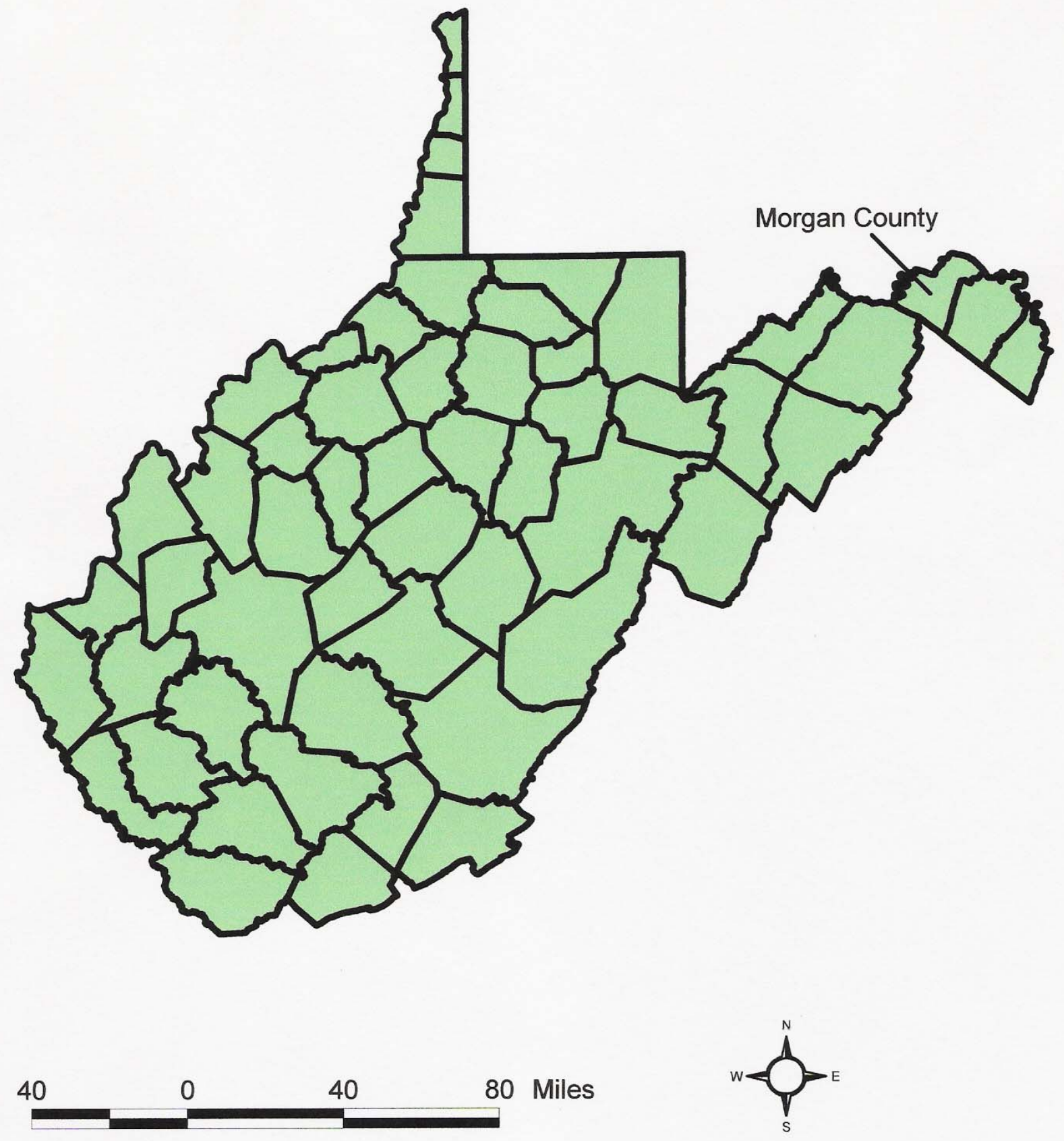

Figure 1: Location of Morgan County within West Virginia. 


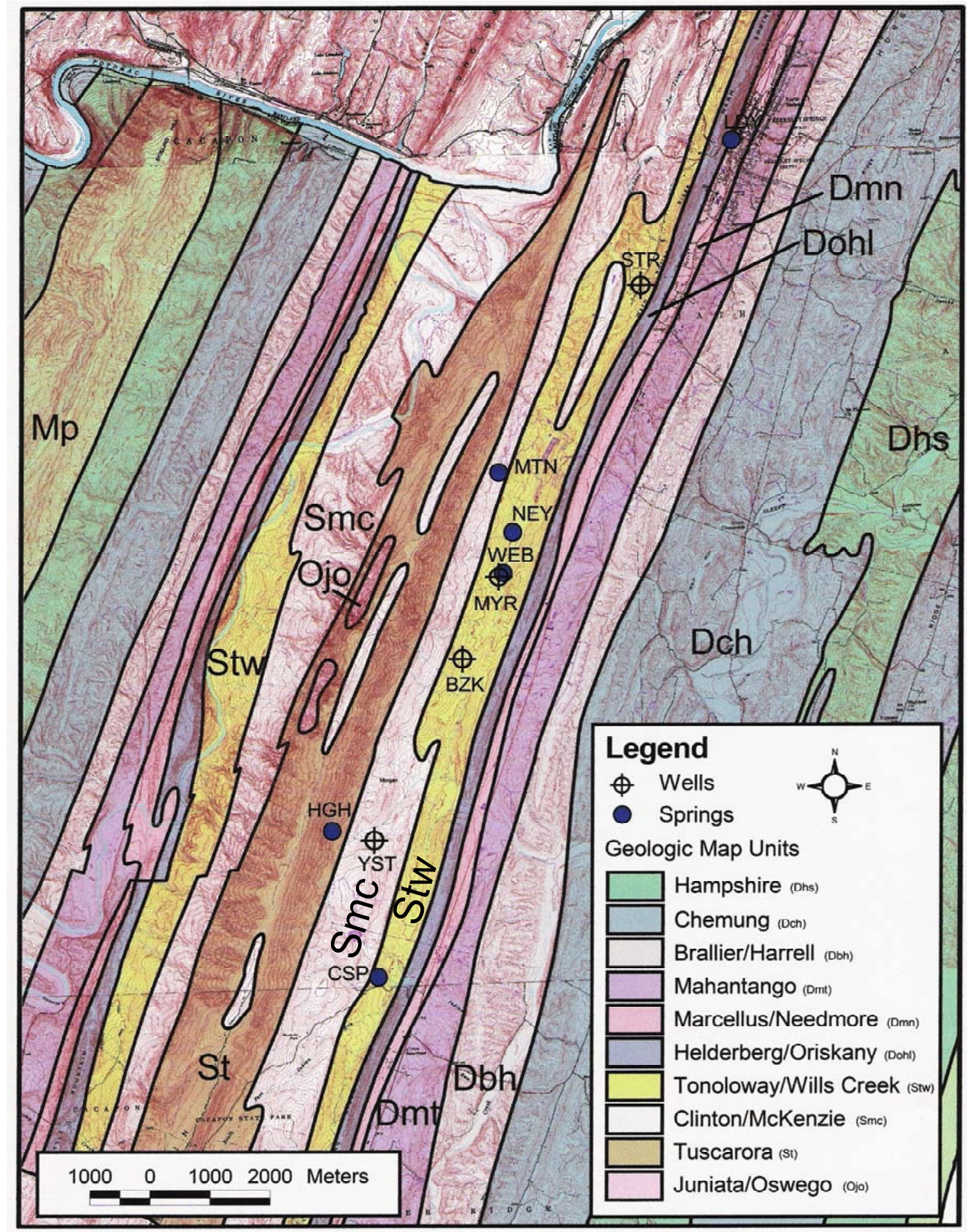

Figure 2: Springs and wells selected for temporal survey. 


\subsection{BACKGROUND}

\subsection{REGIONAL GEOLOGY}

Morgan County, West Virginia is located within the physiographic Valley and Ridge Province, just east of the Allegheny Front (West Virginia Geologic and Economic Survey 2005). Folding and faulting is evident within the region and is prevalent throughout the Valley and Ridge Province. Former movement along these faults is apparent at Berkeley Springs, where slickensides can be found at the Gentleman's spring. Cacapon Mountain, several miles west of Berkeley Springs, marks the axis of the anticlinorium, or series of folded rocks. Rocks dip $50^{\circ}$ eastward from the anticline along the eastern side of Warm Spring Ridge near Berkeley Springs (Grimsley and White 1916). Further south, dips decrease to $35-40^{\circ}$ (Figure 3).

Descriptions of geologic units were taken from several older publications with detailed information pertinent to Morgan County and Cacapon State Park (Grimsley and White 1916; Price and Ludlum 1951; Minke 1964). Geologic descriptions were compared and then matched to geologic units on a digitized map of West Virginia (Cardwell et al. 1968). These descriptions were used in a general fashion to aid in determining local, surficial geology at springs and wells mapped onto the digitized geologic map of West Virginia. The descriptions were beneficial to comparisons between stratigraphy and chemical data.

Cacapon Mountain is capped by the Tuscarora (Medina) Formation (Grimsley and White 1916). Its thickness is approximately $61 \mathrm{~m}$ (200 ft) (Price and Ludlum 1951). This hard, white, quartzose sandstone is the oldest rock within the study area (Figure 4).

Following the eastward dip of the anticline, the next youngest rocks comprise the Silurian Clinton Group/McKenzie Formation. They are roughly $213 \mathrm{~m}(700 \mathrm{ft})$ thick and consist of shaley sandstone, sandstone, shale, and shaley limestone (Price and Ludlum 


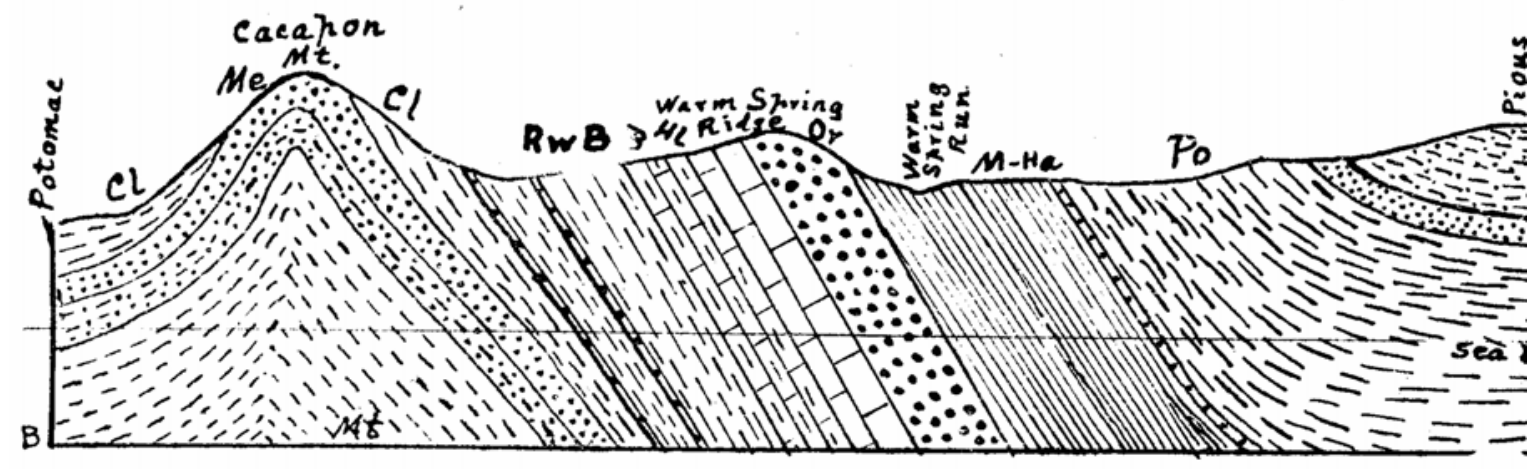

Figure 3: Cross section of Cacapon Mountain anticline- Grimsley and White (1916). 


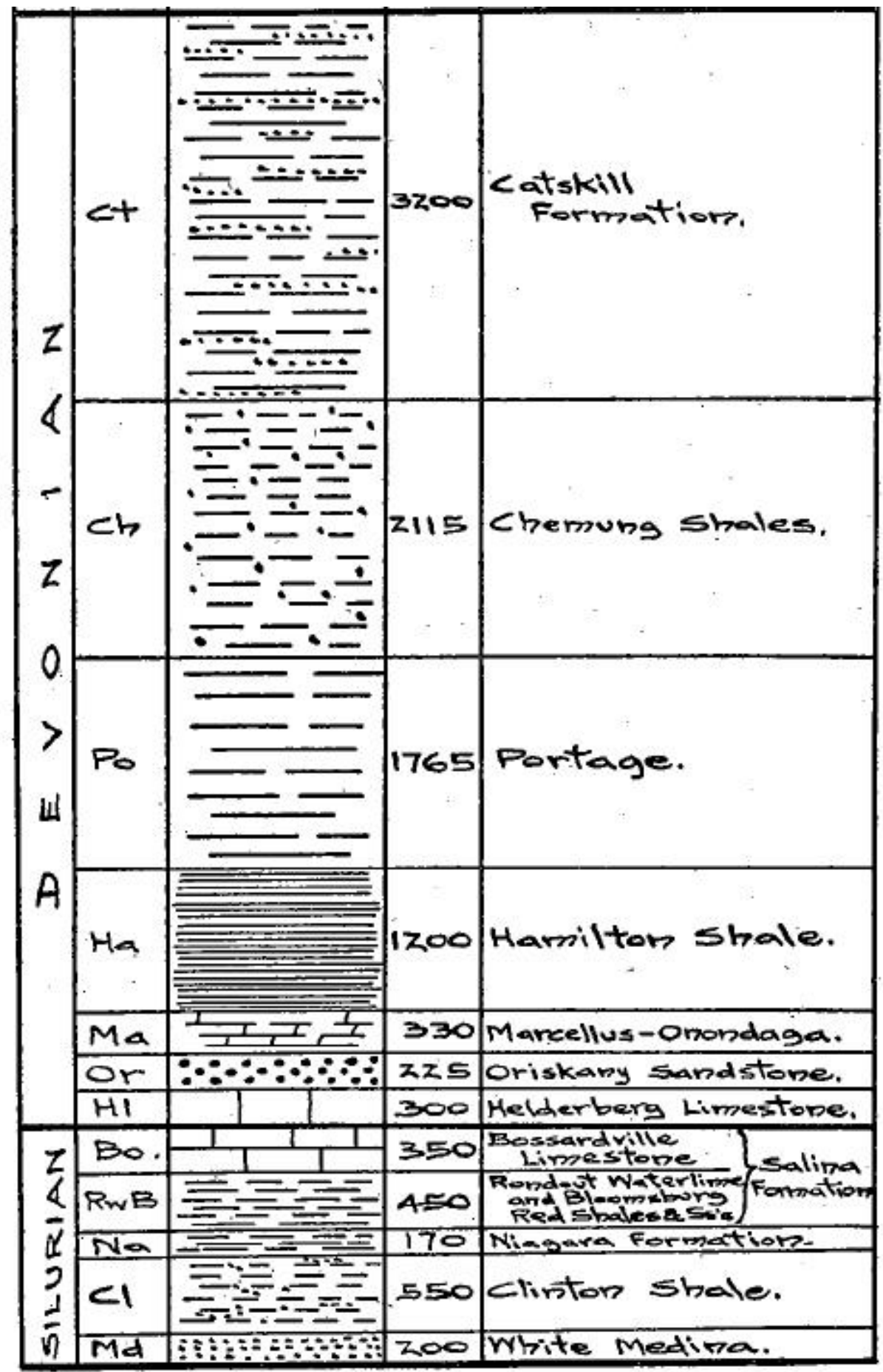

Figure 4: Stratigraphic column- Grimsley and White (1916). 
1951). Colors range from red, to olive, to buff, with red signifying the presence of iron (Fe) oxides (Grimsley and White 1916).

The last sediments to be deposited in the Silurian formed the Wills Creek (Rondout Waterlime), and Tonoloway (Bossardville) formations (Price and Ludlum 1951). These limestone rocks total $244 \mathrm{~m}$ (800 ft) in thickness and comprise the Salina Formation (Grimsley and White 1916).

The overlying Helderberg Group consists of the Helderberg limestone and the Oriskany or Ridgeley sandstone (Price and Ludlum 1951). This group is approximately 122 m (400 ft) thick and includes shaley intervals (Grimsley and White 1916).

The Oriskany is described as a quartzose sandstone or vitreous quartz conglomerate. It may be hard, coarse-grained, or granular and is white, brownish-gray, or gray to bluish-gray in color (Grimsley and White 1916).

East of Warm Spring Ridge, the Devonian shales form a broad, shallow syncline (Grimsley and White 1916). These shales include the Marcellus Formation, the Mahantango Formation, and the Brallier and Harrell formations.

\subsection{RELEVANT LITERATURE}

\subsubsection{Karst settings}

Numerous studies have been conducted in regions with karst geology. Since Berkeley Springs has a great many springs and other features typical of karst settings, it is important to compare and contrast these features with those in other areas. In a relevant study, Shuster and White (1971) examined seasonal changes in chemical behavior to distinguish two types of karst flow mechanics, diffuse and conduit. Their work in Pennsylvania suggested that water from both diffuse and conduit springs undergo changes in geochemistry in response to season but that conduit-fed springs are more variable. Water from the diffuse-fed springs was found to be near saturation for calcite for most of the 
year, while water from the conduit-fed springs did not reach saturation. The explanation given was that water discharging from conduit-fed springs was further away from chemical equilibrium than water discharging from diffuse springs. Geochemical parameters, like saturation indices for calcite and dolomite and variation in hardness, were determined to be more useful than other parameters, like hardness and magnesium (Mg) ion concentration, in distinguishing between diffuse and conduit flow mechanics.

A number of other researchers, including Shuster and White (1971), have used calcium to magnesium molar ratios $(\mathrm{Ca} / \mathrm{Mg})$ to ascertain the extent to which spring flow occurs through limestones and dolostones. When ratios were near unity, spring water was designated as having flowed through dolostone (Jacobson and Langmuir 1969). This could be a useful addition to the study since the limestones in the region are not pure.

Somewhat contrasting results were found in an analogous study on the Inner Bluegrass Region of Kentucky (Scanlon and Thrailkill 1987). There, chemical attributes showed no correspondence with physical attributes of springs. Diffuse and conduit-fed springs could not be distinguished by fluctuations in chemical parameters as they were in Pennsylvania. In Kentucky, flow path length and recharge type were shown to have a significant impact on chemical variation, rather than diffuse or conduit-fed flow styles. Investigators concluded that the lack of correlation between physical and chemical characteristics was likely due to dissimilar bedrock and structure between the two sites. The geology at Berkeley Springs is similar to that found in the Nittany Valley of Pennsylvania where clastic ridges border either side of a carbonate valley and the rocks are highly folded and faulted. Hence, it is expected that the results of this research will be more comparable to those found in Pennsylvania than Kentucky. These early studies do not fully account for all of the flow mechanisms in karst- recharge type, storage, types of permeability. However, they provide a framework for understanding variation in spring water chemistry. 


\subsubsection{Structural controls on ground water flow}

In the Valley and Ridge Province ground water flow paths are normally short unless there is a carbonate rock aquifer, like that in Cold Run Valley (Trapp and Horn 1997). In the vadose zone, ground water flow often occurs in a down-dip direction on the slopes and in an along-strike direction in the valley (Ginsberg and Palmer 2002). Through connected conduits in soluble rock, the lengths of these flow paths can increase greatly and converge at one large spring outlet (Trapp and Horn 1997). The orientation of the conduits follows that of the joints and fractures. In unconfined carbonate aquifers located in moist climates, Worthington (1999) suggests that a network of conduits almost certainly exists. A spring may be considered an outlet for a conduit network when there is no evidence of faults or a highly permeable rock unit at the spring.

The presence of thermal springs is sometimes controlled by structure. In the Appalachians, it is not uncommon to find these springs in carbonate valleys adjacent to ridges (Dethier and Harman 1998). Secondary porosity and permeability created by jointing or faulting can provide conduits for ground water to reach the surface where it is expelled at springs (Bedinger et al. 1979). 


\subsection{METHODOLOGY}

This section summarizes the selection of wells and springs, methods of data collection, procedures for data analysis, and assessment of data quality. Equipment accuracies and potential errors have been summarized (Appendix Table A-1). The sampling program consisted of two components: a regional, synoptic survey of well water levels, pHs, and specific conductances (SC), and a detailed, temporal study of well and spring water chemistries, discharges, and stages or static water levels (SWL).

\subsection{SYNOPTIC WELL SURVEY}

\subsubsection{Site selection}

A regional, synoptic survey of domestic wells commenced May 15, 2004 and ended the first week of August 2004. Approximately 125 wells were surveyed for SWL, pH, and SC. Homeowners were asked to provide details about their wells and water quality including well depth, casing depth, presence of filters or water softeners, odors, smells, rock type, driller name, well usage, and history of drought. Chemical measurements were not made on wells that had filters or water softeners unless requested by the owner. These data were not used in the study and were collected solely for the homeowners' benefit.

Wells were chosen based upon their geographical location and accessibility for measurement. Homeowners who were interested in the research or willing to participate granted entry to their property. Wells were selected to provide the greatest possible spatial distribution of the data and to capture topographic highs and lows that would be evident in the SWL data. The wells were located largely within Cold Run Valley, Rock Gap, or surrounding Sir Johns Run, as these homeowners did not have city water available to them. South of the city's limits, most wells were sampled just east of the Route 522 corridor. 


\subsubsection{Mapping of well locations}

Well locations were collected using a GARMIN eTrex Vista ${ }^{\circledR}$ Global Positioning System (GPS). Ninety-five percent of the time, this GPS unit is spatially accurate within 15 $\mathrm{m}$ (eTrex Vista 2001). In the field, the accuracy reported by the unit ranged from $2.44 \mathrm{~m}$ to

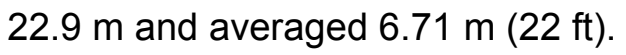

Well locations were overlaid onto 1:24,000-scale USGS Digital Raster Graphics (DRG). The DRGs are USGS digitized and georeferenced topographic maps that have been fitted to a Universal Transverse Mercator projection, Zone 17N (USGS 2005). The projection was based on a North American Datum of 1983 (NAD83). Land surface elevations at wells and springs were ascertained by interpolating between topographic contours.

\subsubsection{Static water level (SWL) measurement}

A graduated steel tape was used to measure SWLs following the method of Lapham et al. (1971). At each site, a measuring point was selected at the top of the well casing. The watermark, or length of submergence of the tape, was subtracted from the amount of tape lowered into the well and recorded as the depth-to-water level. SWL was then calculated by subtracting the depth-to-water measurement from the surface elevation of the well.

\subsubsection{Chemical screening data measurements}

The $\mathrm{pH}$, temperature, and SC measurements were collected at each well. Error in fieldwork was estimated by repeating measurements and reduced by calibrating the instruments daily. The percent error for $\mathrm{pH}$ and temperature measurements collected in the field was less than $1 \%$ when repeated four times at one site. SC measurements agreed within $1.3 \%$ when repeated six times at one site. The conductivity meter was calibrated with 
a standard solution of $1408 \mu \mathrm{S} / \mathrm{cm}$. Commercial buffers of $\mathrm{pH} 4$ and 7 were used for $\mathrm{pH}$ calibration. The $\mathrm{pH}$ meter's automatic temperature compensation (ATC) function adjusted the $\mathrm{pH}$ value based on the water's temperature. Distilled water was routinely used to rinse the probes between measurements.

\subsection{TEMPORAL STUDY}

A detailed, temporal study of four wells and six springs was performed during seven months from September 2004 to April 2005 (Figure 2). Site selection was based upon accessibility, location, spring size, and ease of measurement ascertained during the previous summer months.

\subsubsection{Site descriptions}

Details on sample identification (ID), location, and geology are given for each spring and well (Table 1). Geological descriptions were obtained from a digitized version of a 1968,- 1: 250,000 geologic map of West Virginia (Cardwell et al. 1968). The geologic units depict surface geology. A description of the wells follows.

- STR Well is the northernmost of the four wells. It is approximately $3.2 \mathrm{~km}(2 \mathrm{mi})$ south of Berkeley Springs and is within $6 \mathrm{~m}$ of Cold Run Valley road.

- MYR Well is located in a flat-lying area, near to Cold Run Valley road. It was chosen due to its proximity to WEB spring.

- BZK Well is found in the foothills of Cacapon Mountain on its eastern flank. Because this well is newer, its depth and casing length are known from markings on the well cap.

- YST Well is located high on the slope of Cacapon Mountain and was selected for its distinct topographical location, accessibility, and newness. The well depth and casing length are known. 
Table 1: Coordinates, ID, sample type, and geology at selected springs and wells.

\begin{tabular}{|c|c|c|c|c|c|}
\hline Location & $\begin{array}{c}\text { UTM } \\
\text { Coordinates } \\
\end{array}$ & $\begin{array}{l}\text { Latitude } \\
\text { Longitude } \\
\end{array}$ & $\begin{array}{c}\text { Sample ID } \\
\text { (Historic Names) } \\
\end{array}$ & $\begin{array}{c}\text { Sample } \\
\text { Type }\end{array}$ & Geology at Spring Mouth \\
\hline $\begin{array}{l}\text { Berkeley } \\
\text { Springs State } \\
\text { Park }\end{array}$ & $\begin{array}{c}737804 \\
4389947\end{array}$ & $\begin{array}{l}39.63 \\
-78.28\end{array}$ & $\begin{array}{l}\text { LDY “Ladies'” } \\
\text { (Berkeley Springs- } \\
\text { McColloch 1986) }\end{array}$ & Spring & Oriskany (SS) \\
\hline $\begin{array}{l}\text { Cold Run } \\
\text { Valley }\end{array}$ & $\begin{array}{c}736301 \\
4387510\end{array}$ & $\begin{array}{l}39.60 \\
-78.28\end{array}$ & STR & Well & $\begin{array}{l}\text { Tonoloway, Wills Creek, } \\
\text { Williamsport formations } \\
\text { (LS, SS, Sh) }\end{array}$ \\
\hline $\begin{array}{l}\text { Cold Run } \\
\text { Valley }\end{array}$ & $\begin{array}{c}733954 \\
4384379\end{array}$ & $\begin{array}{l}39.58 \\
-78.28\end{array}$ & $\begin{array}{c}\text { MTN } \\
\text { "Mountainside" } \\
\text { (Coolfont Spring- } \\
\text { McColloch 1986) }\end{array}$ & Spring & $\begin{array}{c}\text { Clinton Group/McKenzie } \\
\text { Formation } \\
\text { (SS, Sh) }\end{array}$ \\
\hline $\begin{array}{l}\text { Cold Run } \\
\text { Valley }\end{array}$ & $\begin{array}{c}734186 \\
4383370\end{array}$ & $\begin{array}{l}39.57 \\
-78.27\end{array}$ & $\begin{array}{l}\text { NEY } \\
\text { "Neely" }\end{array}$ & Spring & $\begin{array}{l}\text { Tonoloway, Wills Creek, } \\
\text { Williamsport formations } \\
\text { (LS, SS, Sh) }\end{array}$ \\
\hline $\begin{array}{l}\text { Cold Run } \\
\text { Valley }\end{array}$ & $\begin{array}{c}734029 \\
4382692\end{array}$ & $\begin{array}{l}39.56 \\
-78.28\end{array}$ & WEB & Spring & $\begin{array}{l}\text { Tonoloway, Wills Creek, } \\
\text { Williamsport formations } \\
\text { (LS, SS, Sh) }\end{array}$ \\
\hline $\begin{array}{l}\text { Cold Run } \\
\text { Valley }\end{array}$ & $\begin{array}{c}733956 \\
4382626\end{array}$ & $\begin{array}{l}39.56 \\
-78.28\end{array}$ & MYR & Well & $\begin{array}{l}\text { Tonoloway, Wills Creek, } \\
\text { Williamsport formations } \\
\text { (LS, SS, Sh) }\end{array}$ \\
\hline Rock Gap & $\begin{array}{c}733354 \\
4381244\end{array}$ & $\begin{array}{l}39.55 \\
-78.28\end{array}$ & BZK & Well & $\begin{array}{l}\text { Tonoloway, Wills Creek, } \\
\text { Williamsport formations } \\
\text { (LS, SS, Sh) }\end{array}$ \\
\hline $\begin{array}{l}\text { Cacapon State } \\
\text { Park- Rock } \\
\text { Gap }\end{array}$ & $\begin{array}{c}731199 \\
4378357\end{array}$ & $\begin{array}{l}39.52 \\
-78.30\end{array}$ & $\begin{array}{l}\mathrm{HGH} \\
\text { (High) }\end{array}$ & Spring & $\begin{array}{l}\text { Tuscarora Formation } \\
\text { (Quartzite) }\end{array}$ \\
\hline Rock Gap & $\begin{array}{c}731901 \\
4378197\end{array}$ & $\begin{array}{l}39.52 \\
-78.31\end{array}$ & YST & Well & $\begin{array}{c}\text { Clinton Group/McKenzie } \\
\text { Formation } \\
\text { (SS, Sh) }\end{array}$ \\
\hline $\begin{array}{l}\text { Cacapon State } \\
\text { Park }\end{array}$ & $\begin{array}{c}731979 \\
4375902\end{array}$ & $\begin{array}{l}39.50 \\
-78.30\end{array}$ & $\begin{array}{c}\text { CSP } \\
\text { “Cacapon State Park" } \\
\text { (Cacapon State Park } \\
\text { Spring- McColloch } \\
\text { 1986) }\end{array}$ & Spring & $\begin{array}{l}\text { Tonoloway, Wills Creek, } \\
\text { Williamsport formations } \\
\text { (LS, SS, Sh) }\end{array}$ \\
\hline
\end{tabular}

LS- limestone; SS- sandstone; Sh- shale. 
Springs are scattered throughout the study region and exist in heterogeneous topographic settings. Knowledge of their whereabouts was acquired from the West Virginia state inventory, community members that participated in the summer well survey, and from collaborating researchers to the research project. Springs were chosen if they were large enough to be measured for discharge with a bucket and stopwatch or could be monitored for stage. A description of the springs follows.

- LDY (Ladies' Spring) is one of several warm springs discharging from the Oriskany Formation at the eastern base of Warm Spring Ridge. These warm springs are located in Berkeley Springs State Park in the town of Bath. LDY was preferred for sampling over the other warm springs due to its large size, locked entry, and ability to accommodate a data logger and staff gage.

- MTN (Mountainside) Spring, near Coolfont resort, is located on the eastern slope of Cacapon Mountain. Although the spring is no longer used, it once provided drinking water for the housing development. The soft sediment from which it issues is protected by a metal cap and concrete seal.

- NEY (Neely) Spring discharges into Sir Johns Run. It is used for domestic purposes and is protected by a springhouse. The spring is located at the base of a steep hill sloping down from Cold Run Valley road.

- WEB Spring also discharges into Sir Johns Run and is protected by a springhouse. It is found in a low, saturated, flat-lying area at a slightly lower elevation than Cold Run Valley road.

- HGH Spring, unlike all of the other springs, is situated near a topographic high on the eastern side of Cacapon Mountain in Cacapon State Park. It is less than $1 \mathrm{~km}$ from the summit and is the only spring that is unprotected by a cap or springhouse.

- CSP Spring is located in the gently rolling valley area of Cacapon State Park, east of Cacapon Mountain. It is protected by a cap and springhouse and was once used for 
drinking water. Visitors now receive water from a number of wells situated throughout the park.

\subsubsection{Hydraulic measurements}

Spring stage and discharge were measured according to each site's physical constraints. Stage was measured as the distance from a permanent reference to the water's surface. Spring discharge was obtained with a large bucket and stopwatch. To quantify error in making this estimate, the discharge measurement was repeated five times at one sampling location. The coefficient of variation (COV) was $17 \%$.

Discharge at WEB spring was measured from a plastic pipe draining the spring. At MTN, discharge was measured about $15 \mathrm{~m}$ downstream of the culvert, rather than at the head of the spring. This was the only position where a bucket could be successfully placed to collect water.

At $\mathrm{HGH}$, discharge was measured along the spring run as the water was ponded at the spring. The channel narrowed downstream at a small waterfall, making the measurement easier to take. This measurement was an estimate of about $80 \%$ of the spring's discharge. Discharge could not be measured at the other springs as there was no acceptable location for placing a bucket. A flow meter could not be used, because the spring runs were too shallow.

\subsubsection{Sample collection and chemical analyses}

Water sample collection began in September 2004 and ended in April 2005. Sites were sampled five to seven times, depending on location (Table 2). As sampling progressed, different analytes were added or excluded from laboratory analyses depending on preliminary data, laboratory equipment availability, and pertinence of the analyte to research. 
Table 2: Number and timing of water samples at selected locations.

\begin{tabular}{|c|c|c|c|c|c|c|c|c|}
\hline Location & $\begin{array}{c}\text { Total \# } \\
\text { of Times } \\
\text { Water } \\
\text { Sampled }\end{array}$ & 4-Sep & 4-Oct & 4-Nov & 4-Dec & 5-Feb & 5-Mar & 5-Apr \\
\hline LDY & 7 & & & & & & & \\
\hline STR & 5 & $\mathrm{NC}$ & & & & NC & & \\
\hline MTN & 7 & & & & & & & \\
\hline NEY & 7 & & & & & & & \\
\hline WEB & 7 & & & & & & & \\
\hline MYR & 6 & NC & & & & & & \\
\hline BZK & 6 & NC & & & & & & \\
\hline $\mathrm{HGH}$ & 6 & & & & & & $\mathrm{NC}$ & \\
\hline YST & 6 & & & & & & $\mathrm{NC}$ & \\
\hline CSP & 7 & & & & & & & \\
\hline
\end{tabular}

Shaded cells indicate collection of chemical samples.

NC indicates that a sample was not collected that month. 
All 10 sites were measured for $\mathrm{pH}$, temperature, SC, and alkalinity once monthly. Temperature, $\mathrm{pH}$, and $\mathrm{SC}$ readings were recorded concurrently with the collection of water samples. Sample bottles, filter cartridges, and syringes were rinsed with sample water at least three times before collecting any water. Samples for cation and anion analyses were then filtered with $0.45-\mu \mathrm{m}$ disposable cartridge filters. Cation samples were preserved with nitric acid. All samples were kept on ice to minimize any chemical reactions associated with microorganisms.

Alkalinity was calculated using a two-point gran titration to pHs 4.2 and 3.9 (Rounds and Wilde 2002). It was measured in the field when possible or within 24 hours to diminish the effects of degassing and microbial activity. Total alkalinity was calculated by using the volume of titrant, normality of acid, and sample volume (APHA et al. 2005). Alkalinity measurements were repeated six times on a single sample in order to estimate precision. Values agreed within $7 \%$. Alkalinity data are reported in $\mathrm{mg} / \mathrm{L}$ as bicarbonate $\left(\mathrm{HCO}_{3}\right)$.

Chemical measurements were conducted at the spring head for all but one of the springs. At CSP, sampling was conducted about $15 \mathrm{~m}$ outside of the springhouse, where it discharges from the ground. Inaccessibility prevented measurements from being taken inside the springhouse.

At all well locations except YST, chemical measurements were taken in small plastic beakers filled with water from a nearby hand pump tapping the well. Chemical data were collected differently at YST because of the lack of a hand pump. There, water was taken from an outside tap and dispensed in plastic beakers after turning off the water softener and letting the water run for 10 to 15 minutes.

Anions were analyzed by lon Chromatography (IC), while cation samples were analyzed using Inductively Coupled Plasma-Optical Emission Spectroscopy (ICP-OES) (Table 3). Chemical analyses were conducted by the National Research Center for Coal and Energy Analytical Laboratory. 
Table 3: Summary of analytical methods and sample collection and preservation.

\begin{tabular}{lccccc}
\hline Analytes & Filtered/Unfiltered & $\begin{array}{c}\text { Bottle } \\
\text { Type }\end{array}$ & Preservative & $\begin{array}{c}\text { Analytical } \\
\text { Instrument }\end{array}$ & Method \\
\hline $\begin{array}{l}\text { Cations: } \\
\mathrm{Ca}, \mathrm{Mg}, \mathrm{Na}, \mathrm{K},\end{array}$ & Filtered & Plastic & Nitric Acid & ICP-OES & $\begin{array}{c}\text { EPA 200.7 } \\
\text { environmental } \\
\text { se, } \mathrm{Mn}, \mathrm{Si}, \mathrm{S}\end{array}$ \\
$\begin{array}{l}\mathrm{Anions}: \\
\mathrm{SO}_{4}, \mathrm{Cl}, \mathrm{NO}_{3}\end{array}$ & Filtered & Plastic & None & IC & EPA 300.0 \\
\hline
\end{tabular}

As laboratory equipment availability changed, methods for analyzing ions changed.

Specific methods are given here: $\mathrm{SO}_{4}$ (375.4 or 375.1), $\mathrm{Cl}(325.2), \mathrm{NO}_{3}(353.2)$

ICP-OES: Inductively Coupled Plasma-Optical Emission Spectroscopy

IC: Ion Chromatography 
A chemical equilibrium model, Visual MINTEQ version 2.30, was used for speciation calculations. This model is a Windows based program adapted from the EPA's MINTEQA2 version 4.0 (Gustafsson 2004).

Using the parameters $\mathrm{pH}$, temperature, alkalinity, and analyte concentration as input, charge balance error $(\mathrm{CBE})$, ionic strength $(\mathrm{I})$, saturation indices for quartz $\left(\mathrm{SI}_{\mathrm{Q}}\right)$, calcite $\left(S I_{C}\right)$, and dolomite $\left(S I_{D}\right)$, and the partial pressure of carbon dioxide $\left(\mathrm{P}_{\mathrm{CO} 2}\right)$ were calculated. Enhanced $\mathrm{P}_{\mathrm{CO} 2}$ values were calculated by normalizing the $\mathrm{P}_{\mathrm{CO} 2}$ concentration to the atmospheric $\mathrm{P}_{\mathrm{CO} 2}\left(\mathrm{P}_{\mathrm{CO} 2 \mathrm{ATM}}\right)$.

\subsection{DATA QUALITY}

In examining error, the most important consideration is how it impacts interpretation of the results. A quality assurance (QA) program was thereby created to quantify the amount of error in field and laboratory methods and to determine whether this error limited the conclusions drawn from the data. A discussion of the program and subsequent findings are presented.

Three blind duplicates made from split samples were sent to the laboratory to check for laboratory or method precision. The average percent difference for duplicate samples from original samples was approximately $13 \%$. The percent difference was much greater for some of the analytes at small concentrations than for analytes at large concentrations. For instance, the difference for $\mathrm{NO}_{3}$ was $133 \%$ for one duplicate. All other percent differences ranged between $0 \%$ and $32 \%$.

- To assess the laboratory's accuracy, six standards with known concentrations of cations were submitted for analysis. Percent error ranged between $14.7 \%$ and $27.6 \%$.

- To determine if the filter or syringe was contaminating any of the water samples, a filter blank of deionized (DI) water was sent to the lab. Most analytes were present 
at concentrations less than $0.1 \mathrm{mg} / \mathrm{L}$ or below the detection limit of the analysis. It is possible that this affects the concentration of $\mathrm{Ca}$ at the low-concentration springs (MTN and $\mathrm{HGH}$ ), but the impact is minimal and does not impact the interpretation between springs.

Alkalinity values posed a potential problem at sample sites having waters with low alkalinities. How this affected the saturation indices was especially important. Waters from sample sites with low alkalinities had very high COVs for alkalinity, when compared with waters from sample sites with high alkalinities. At sites where waters have little buffering capacities; however, the error in measuring alkalinity ultimately produced higher CBEs. Although the COVs for alkalinity were high for sites having waters with lower alkalinities, interpretation of the $\mathrm{SI}_{\mathrm{C}}$ was unaffected. The two sites having waters with low alkalinities were clearly undersaturated with respect to calcite regardless of the COV. A definite distinction could be made between sites that had waters that were near to equilibrium, slightly undersaturated, undersaturated, or very undersaturated. It was concluded that varying alkalinities did not affect the interpretation of the saturation index for calcite regardless of whether alkalinity concentration was high or low. Conclusions regarding the $S I_{D}$ were similar.

Interpretation regarding $\mathrm{P}_{\mathrm{CO} 2}$ was somewhat impacted. The COV in $\mathrm{P}_{\mathrm{CO} 2}$ values for the sites having waters with the lowest alkalinities was much greater than for other, more alkaline waters. The $\mathrm{P}_{\mathrm{CO} 2}$ is calculated from the $\mathrm{pH}$, so errors in $\mathrm{pH}$ produce errors in enhanced $\mathrm{P}_{\mathrm{CO} 2}$. An approximately $10 \%$ error in $\mathrm{P}_{\mathrm{CO} 2}$ results from an error of $0.05 \mathrm{pH}$ unit (Palmer 2007). If there was an error in the collection of $\mathrm{pH}$, for instance an underestimation in $\mathrm{pH}$ caused by using two different $\mathrm{pH}$ meters, one of which gave lower $\mathrm{pH}$ readings, then this error would be consistent among sites as long as the meter was not switched during any given sampling round. While the enhanced $\mathrm{P}_{\mathrm{CO} 2}$ values through time may have some error, interpretation is not impacted in comparing these sites for any given sampling period. Only 
temporal interpretation of $\mathrm{pH}$ and enhanced $\mathrm{P}_{\mathrm{CO} 2}$ would be affected. Interpretation of $\mathrm{Sl}_{\mathrm{C}}$ was affected similarly by changes in $\mathrm{pH}$. While temporal analysis may have been impacted, for any given sampling round comparisons could still easily be made among locations. Comparisons between mean chemical parameters were also possible and considered not to be affected.

\subsection{STATISTICAL ANALYSIS}

Statistics were used to aid geochemical and hydrologic interpretation in both the synoptic and temporal studies. Correlations with probabilities (P-values) less than a significance of $5 \%(\alpha=0.05)$ are considered to be statistically significant.

Principal Component Analysis (PCA) was performed using Minitab® Statistical Software (2000) and was used to analyze the temporal data while reducing redundancy among the intercorrelated variables (Kachigan 1986). The result was a combination of intercorrelated variables into a few distinct groups or principal components. 


\subsection{RESULTS}

\subsection{SYNOPTIC SURVEY CHEMICAL DATA AND WATER LEVEL DATA}

The screening data collected during the synoptic survey included $\mathrm{pH}, \mathrm{SC}$, and $\mathrm{SWL}$ (Appendix Table A-2). The measured pHs ranged from 5.22 to 7.73 ; the SC from 100 to $945 \mu \mathrm{S} / \mathrm{cm}$. An area of concentrated high SC and high $\mathrm{pH}$ was found within Cold Run Valley in the Tonoloway/Wills Creek formations which are comprised of limestone, shale, and sandstone (Figures 5 and 6). Several wells on the eastern side of Warm Spring Ridge also had waters with both high SC and $\mathrm{pH}$. Surface lithology here consists of shales in the Mahantango or the Brallier/Harrell formations.

The region with a consistently low $\mathrm{pH}$ and $\mathrm{SC}$ was found on the eastern flank of Cacapon Mountain. Wells in this area are most likely completed in the Clinton Group/McKenzie Formation which is comprised of sandstone, calcareous sandstone, and shale or in the non-calcareous Keefer sandstone, which resembles the Tuscarora sandstone (Minke 1964). Wells near the base of Cacapon Mountain may be completed in the more calcareous upper units of the Clinton Group/McKenzie Formation.

A potentiometric surface map was constructed from the water level elevation data to infer regional ground water flow directions (Figure 7). Water level elevations ranged from $141 \mathrm{~m}(464 \mathrm{ft})$ to $377 \mathrm{~m}(1238 \mathrm{ft})$. The highest elevations were generally found in the two areas of greatest vertical relief, Cacapon Mountain and Warm Spring Ridge; the lowest water level elevations were found in the valleys. Water level elevations decreased to the north on the northern side of the ground water divide inferred from the potentiometric contours.

\subsection{TEMPORAL STUDY CHEMICAL DATA AND WATER LEVEL DATA}

The field measurements taken during the temporal study included physical and chemical parameters (Appendix Table A-3). Changes through time are depicted for 


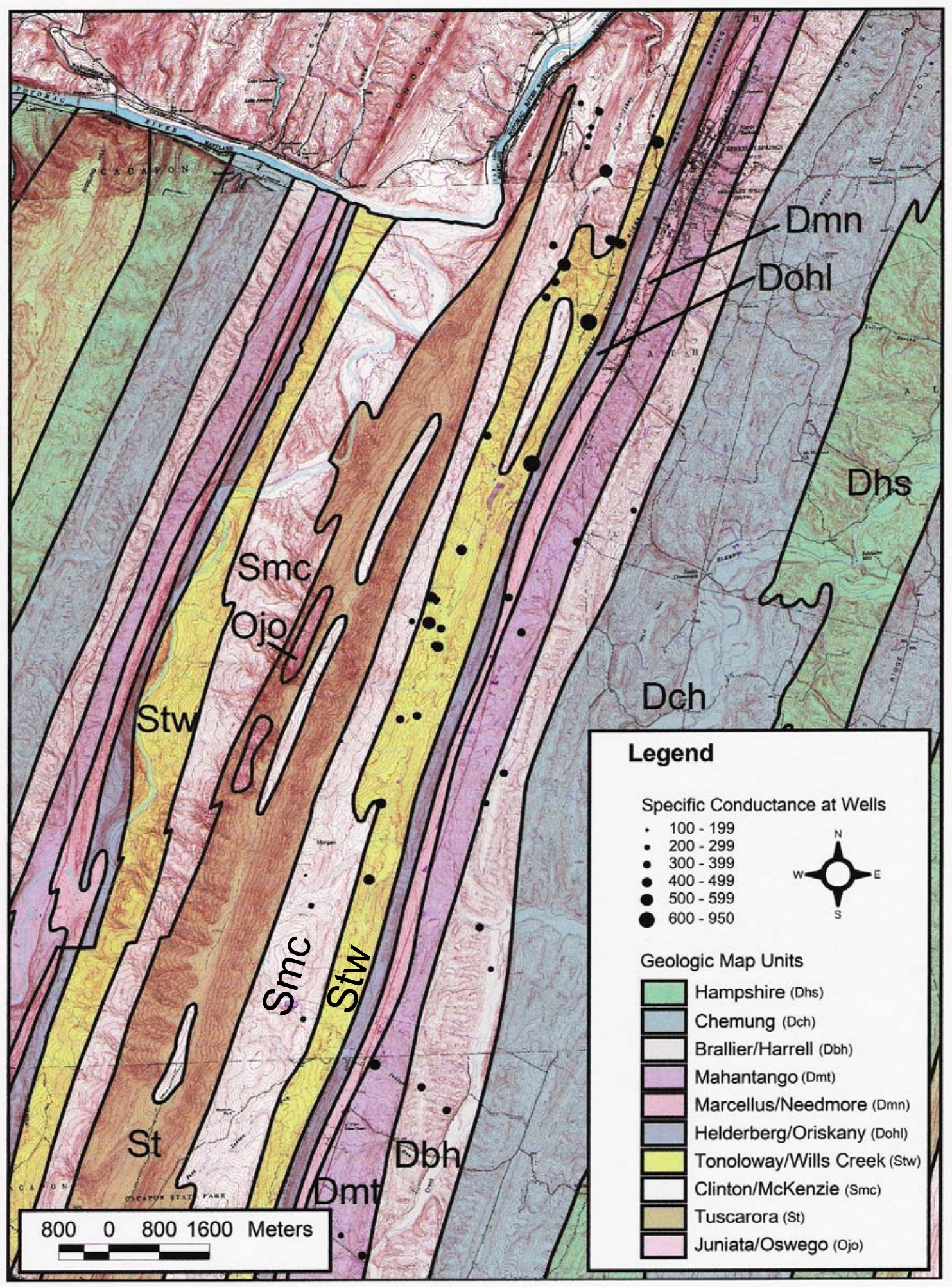

Figure 5: Regional distribution of SC $(\mu \mathrm{S} / \mathrm{cm})$ in study area. 


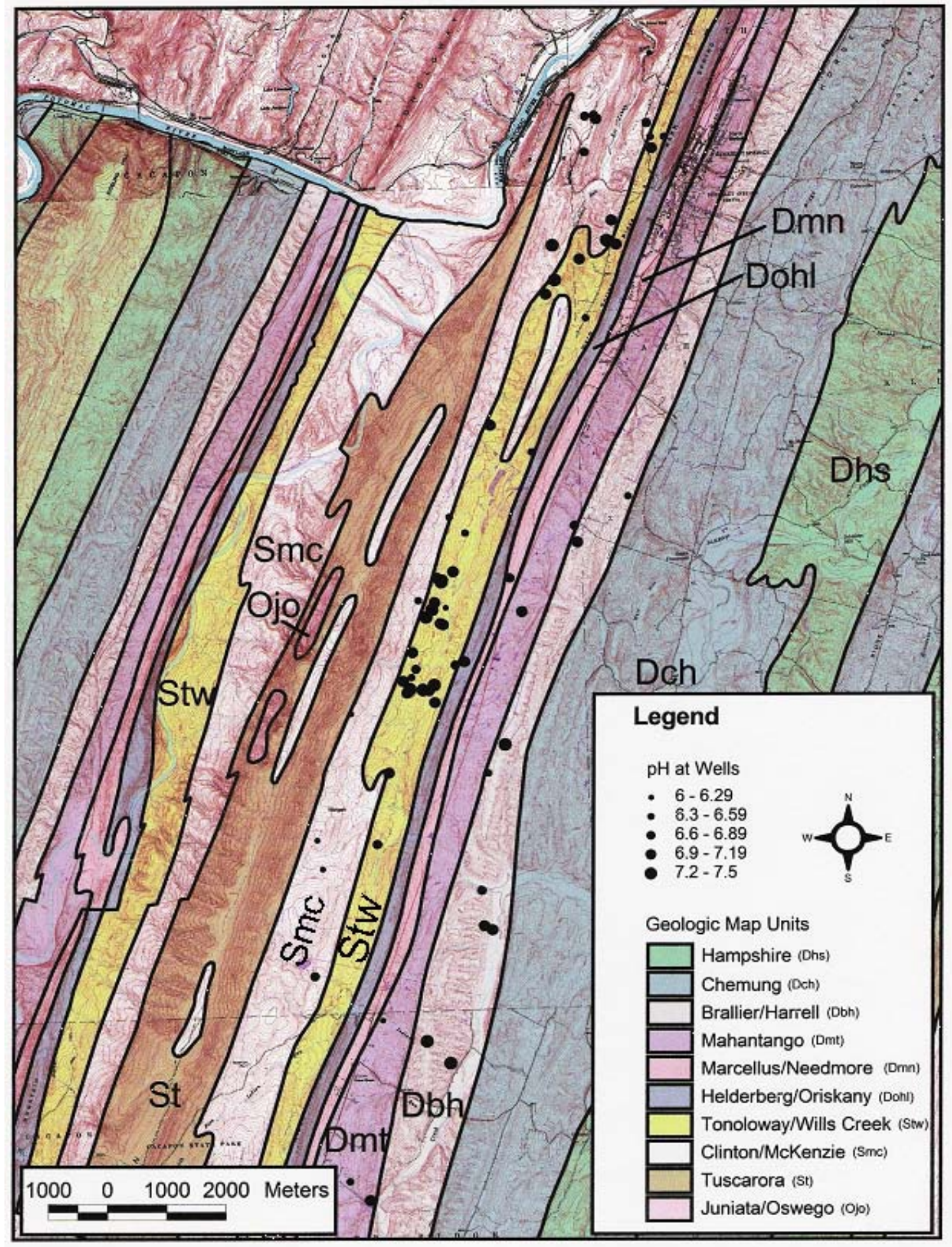

Figure 6: Regional distribution of $\mathrm{pH}$ at wells in study area. 


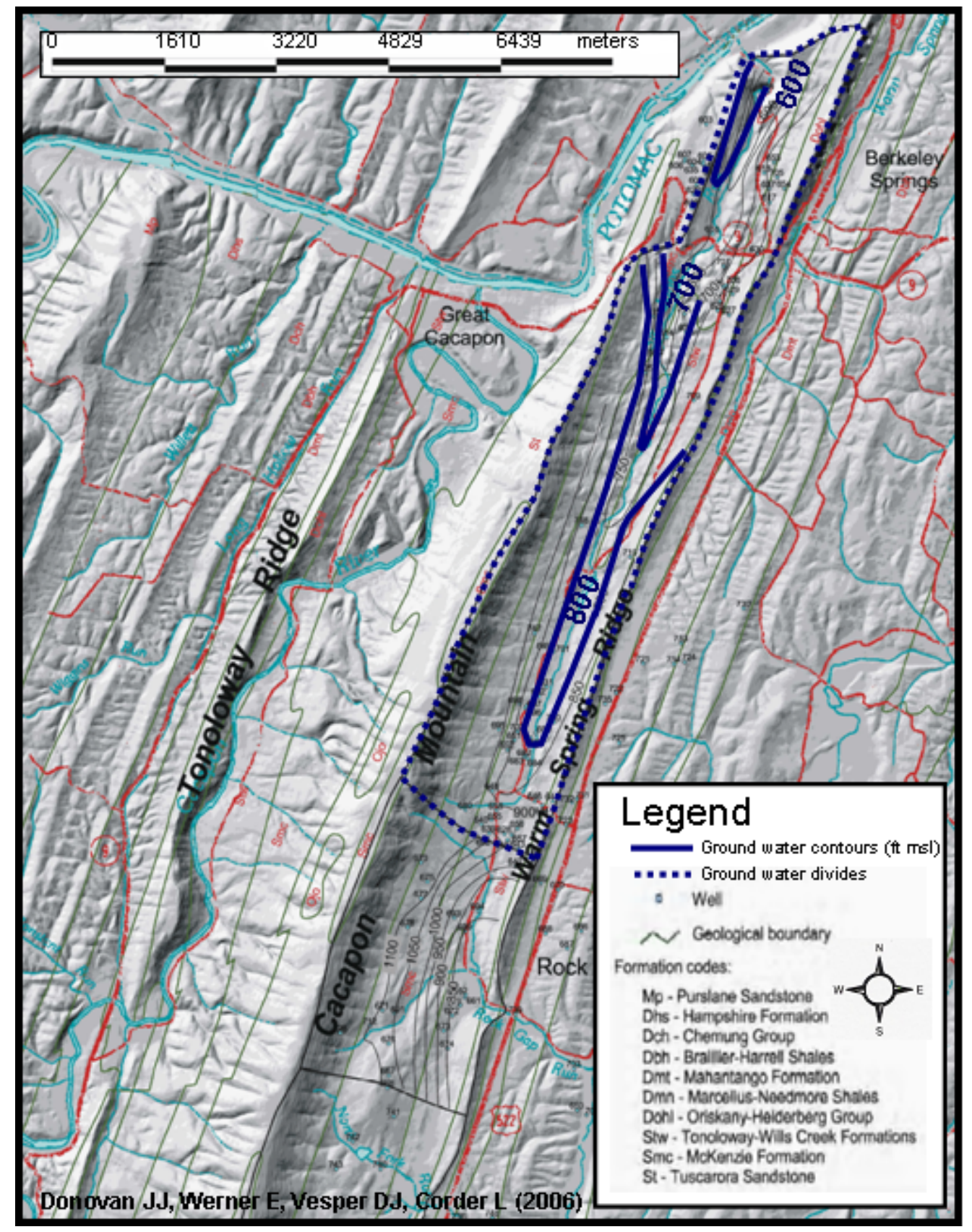

Figure 7: Potentiometric surface. For full details see source reference. 
some parameters for each well and spring (Figures 8-17). Temperature and rainfall data were obtained from the NOAA Berkeley Springs $3 \mathrm{~S}$ station which is located in Berkeley Springs, West Virginia (NOAA 2005; Appendix Tables A-4 and A-5).

The water temperatures ranged from 4.1 to $22.5^{\circ} \mathrm{C}$ over the sampling period. Waters from the wells varied more in temperature than did waters from the springs (Figure 18). Water temperatures in CSP, $\mathrm{HGH}$, WEB, and LDY springs were the most consistent over the studied period. LDY, furthermore, had the highest and least variable water temperatures.

The pHs ranged from 3.97 to 7.33 ; the SCs ranged from 32 to $945(\mu \mathrm{S} / \mathrm{cm})$. Two springs ( $\mathrm{HGH}$ and MTN) had waters with low pH and low SC values, while the remaining springs had higher $\mathrm{pH}$ and SC values (Figure 19a). Waters from BZK and STR wells had higher pHs and SCs than all other sites.

Manganese $(\mathrm{Mn})$ and $\mathrm{NO}_{3}$ concentrations were measured for four and two sampling rounds, respectively (Appendix Table A-6). All concentrations were below the detection limit ( $<0.1 \mathrm{mg} / \mathrm{L})$ for $\mathrm{Mn}$, except in waters from $\mathrm{HGH}$ spring. Its Mn concentrations were slightly above the detection limit for two of the sampling rounds. All sites had relatively low $\mathrm{NO}_{3}$ but MYR. Its concentration ( $3.57 \mathrm{mg} / \mathrm{L})$ was below the EPA's maximum contaminant level of 10 $\mathrm{mg} / \mathrm{L} \mathrm{NO}_{3}$ measured as $\mathrm{N}$ (EPA 2005). Only in waters from $\mathrm{YST}$ well were $\mathrm{Cl}$ and $\mathrm{NO}_{3}$ concentrations below their detection limits.

Si concentrations in spring waters ranged between 1.95 and $5.81 \mathrm{mg} / \mathrm{L}$. In well waters Si concentrations ranged between 2.32 and $4.50 \mathrm{mg} / \mathrm{L}$ (Figure 20). Water from LDY spring had the highest median Si concentration; the range overlapped with Si concentrations in waters from CSP and WEB springs. Mean concentrations have been calculated and summarized for selected parameters (Appendix Table A-7).

All sites, except for MTN and $\mathrm{HGH}$, are in the calcium-bicarbonate hydrochemical facies (Figure 21) (Fetter 2001). MTN has no dominant type of chemistry based on ratios 

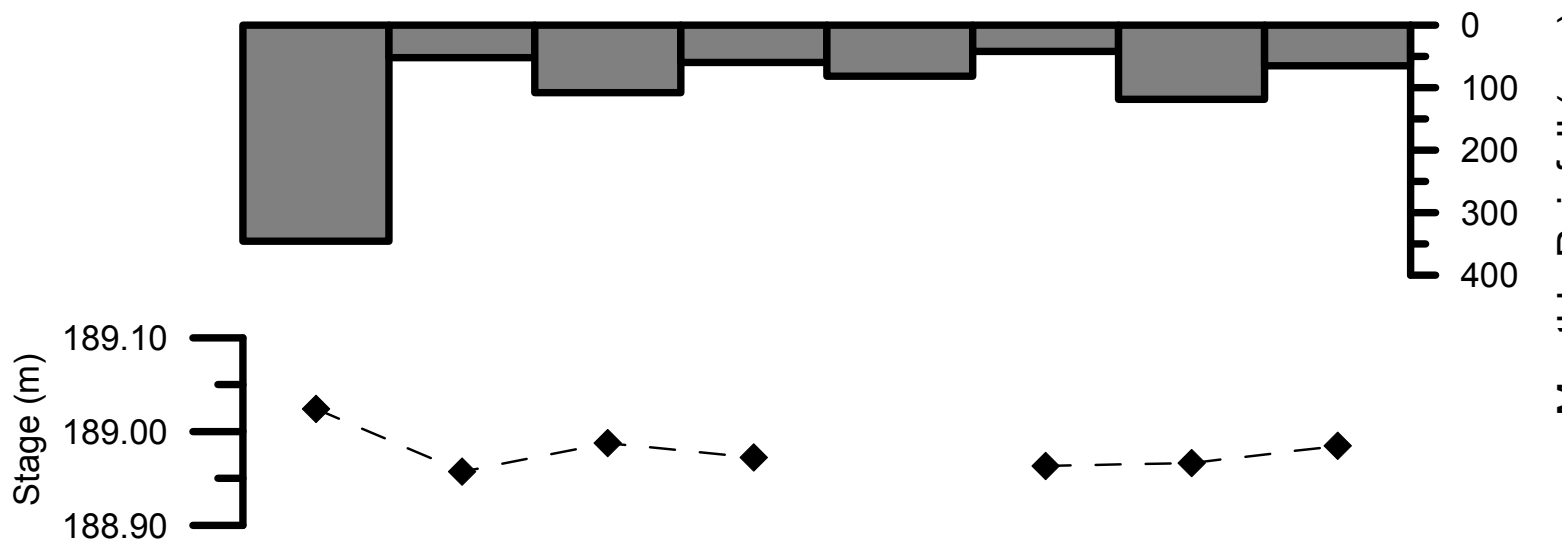

$\begin{array}{lll} & 5.2 & \\ \text { ๖े } & 4.8 \\ \text { छ } & 4.4 & \\ \text { क } & 4.0 & 3.6\end{array}$
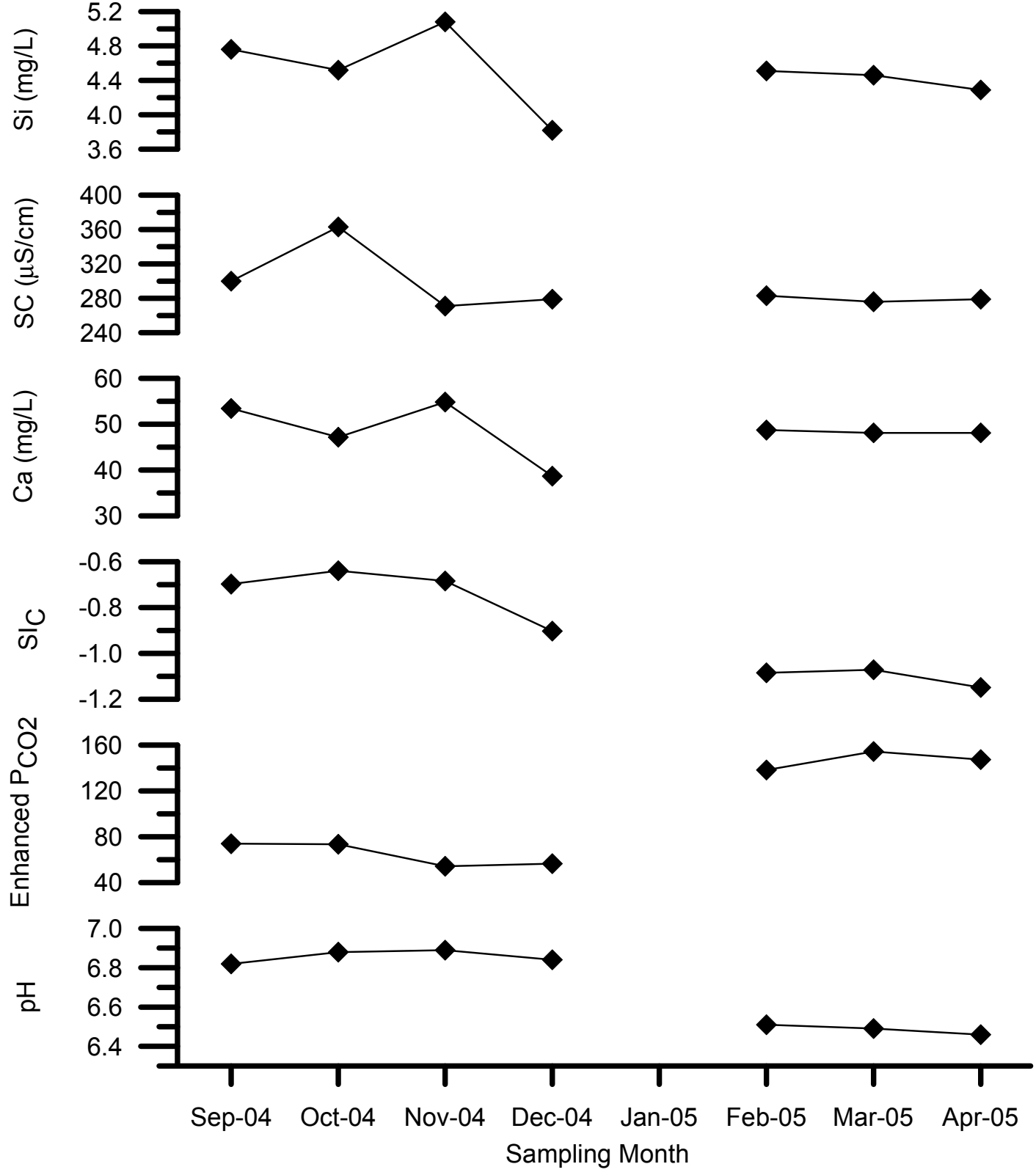

Figure 8: Chemical parameters, stage, and rainfall through time at LDY (Spring). 

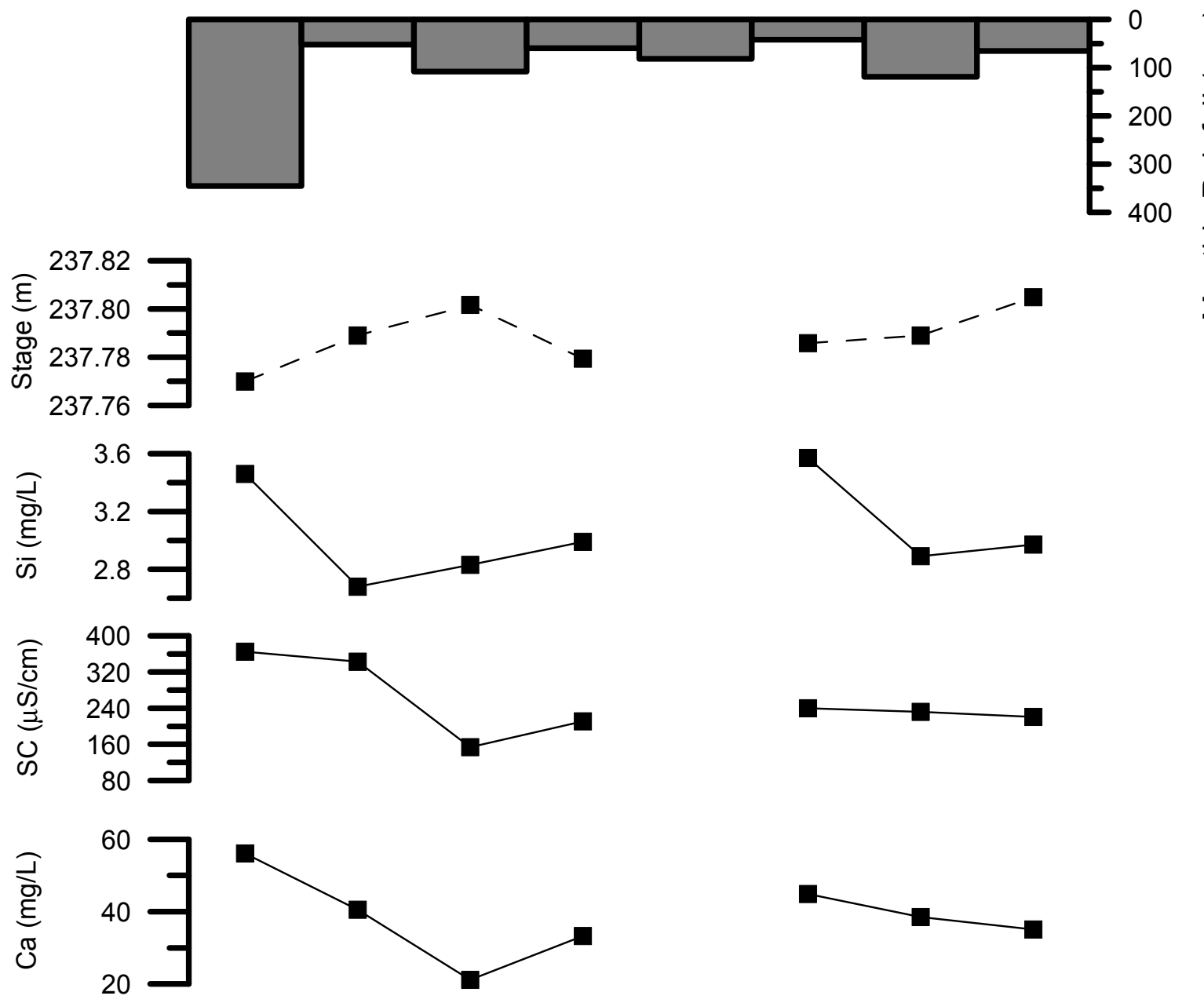

$\begin{array}{lll} & -0.4 & \\ \omega & -0.8 & \\ -1.2 & & \text { J } \\ -1.6 & \end{array}$
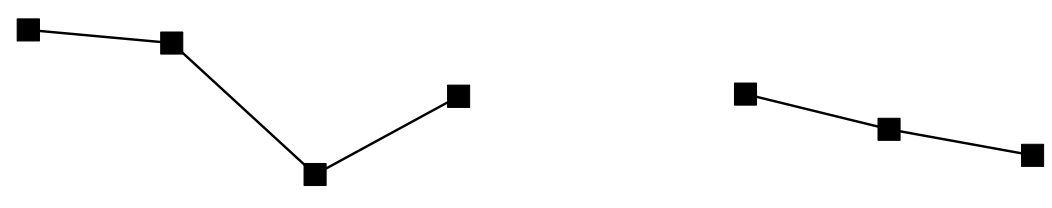

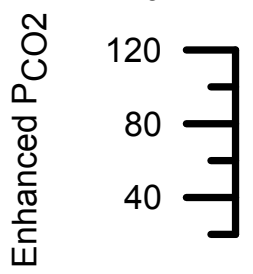
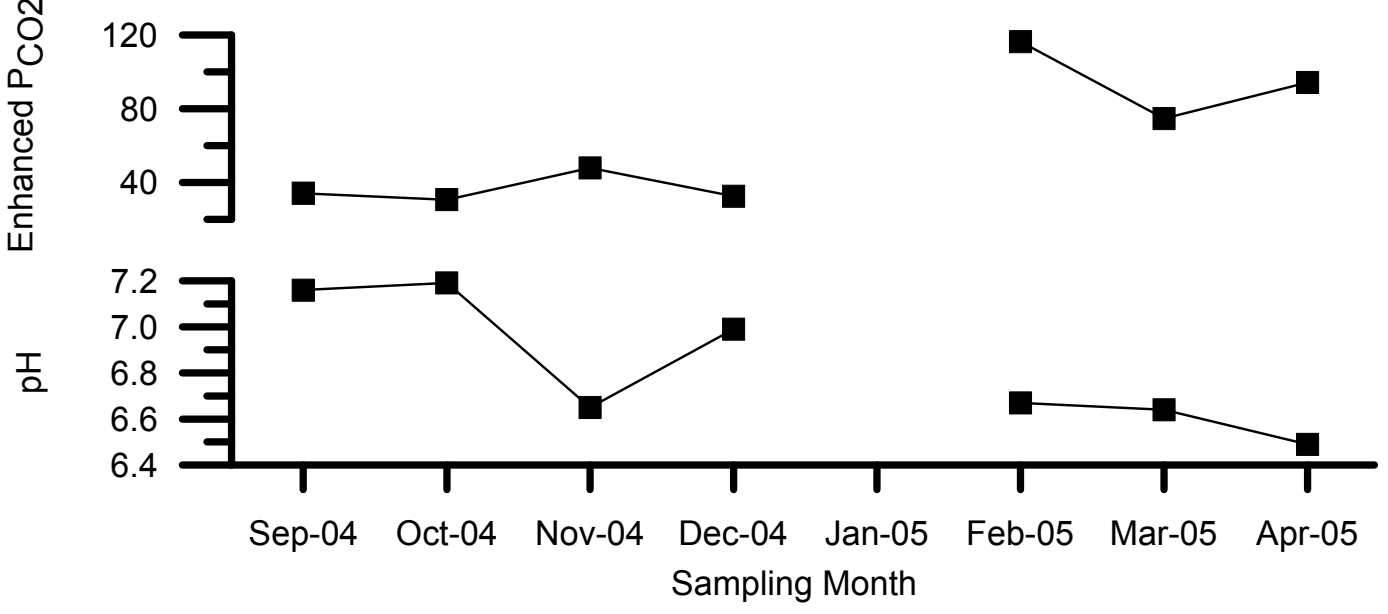

Figure 9: Chemical parameters, stage, and rainfall through time at NEY (Spring). 

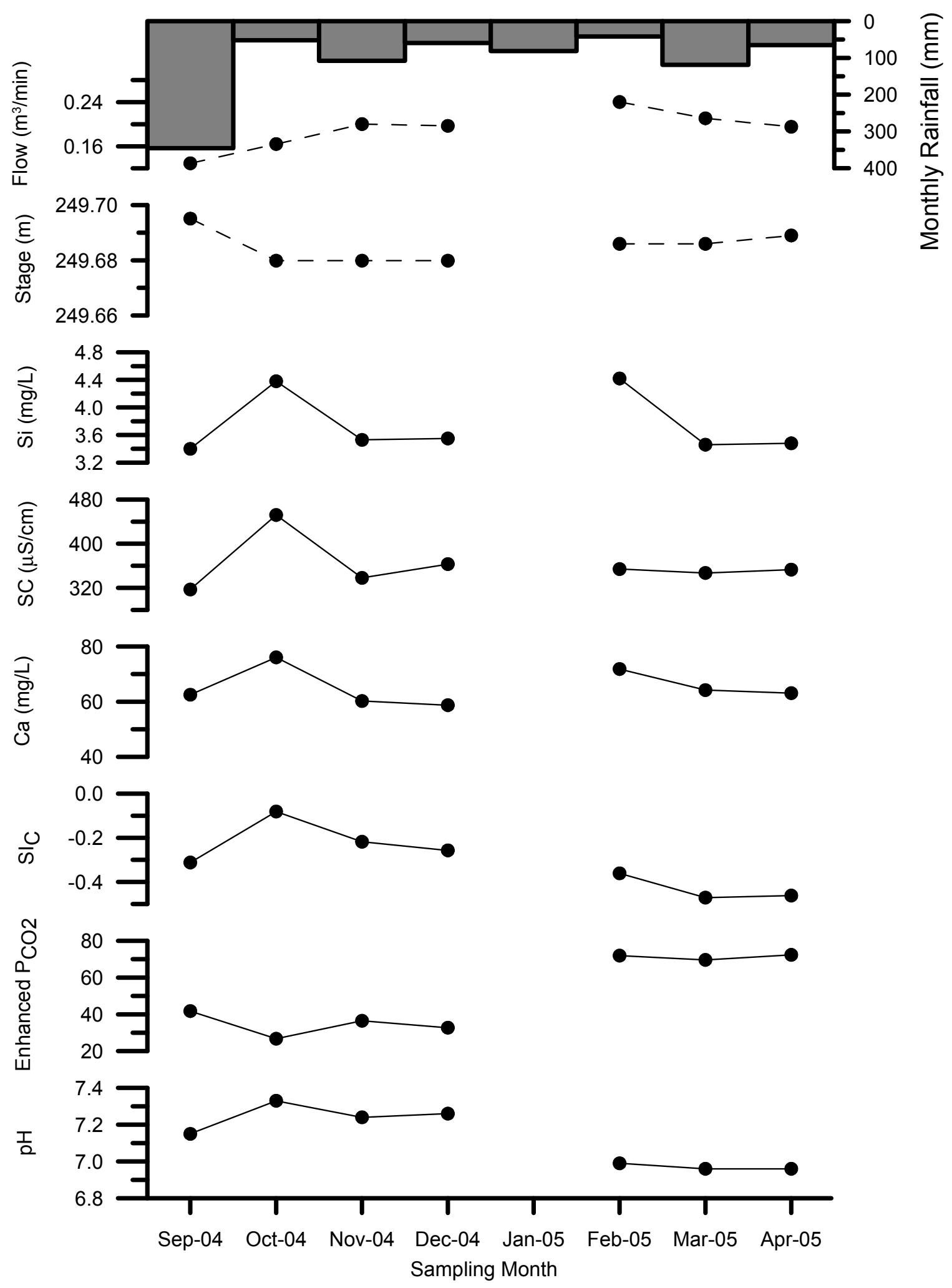

Figure 10: Chemical parameters, stage, and rainfall through time at WEB (Spring). 

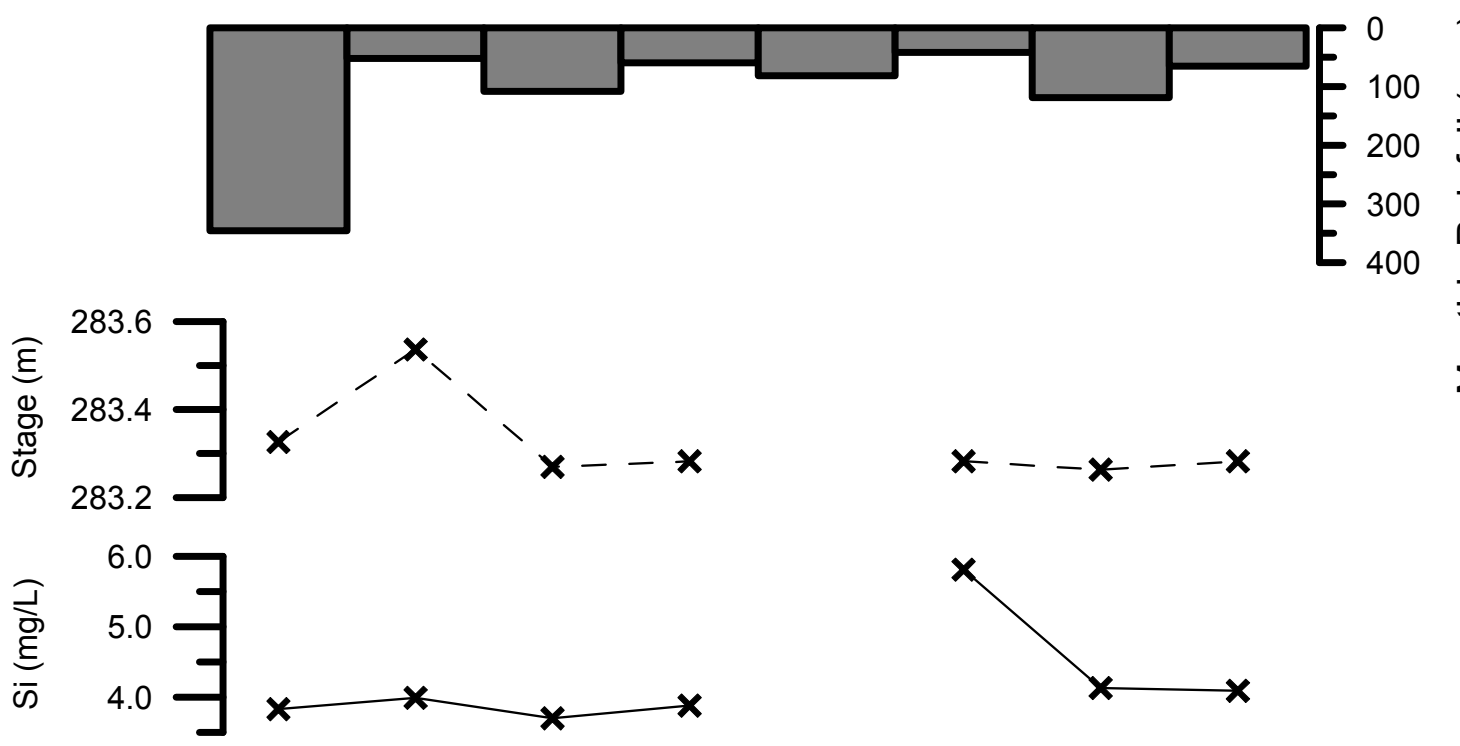

$x--x-x$

$\begin{array}{ll}\underset{\mathcal{E}}{\frac{D}{J}} & 400 \\ \text { U } & 320-\end{array}$
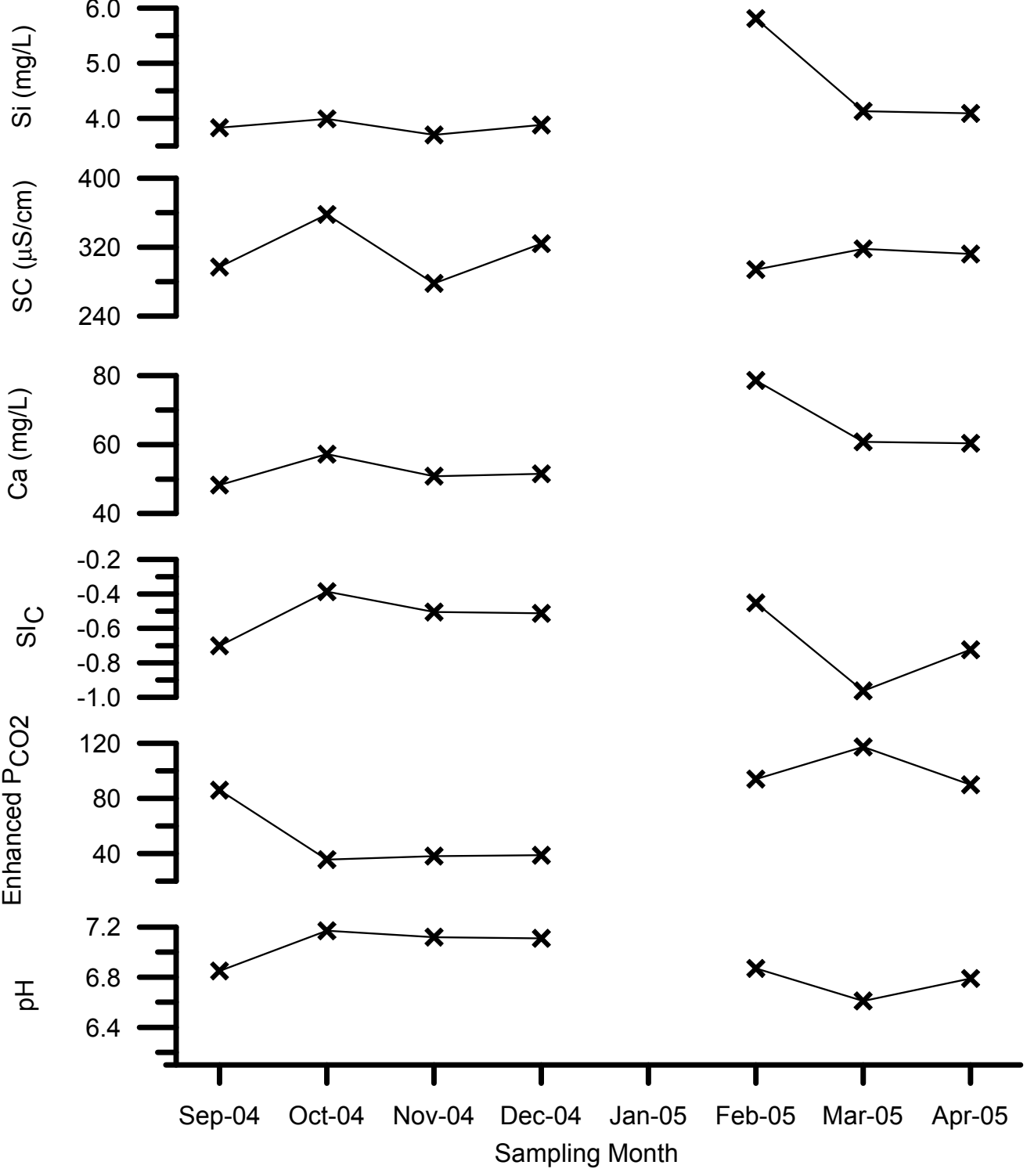

Figure 11: Chemical parameters, stage, and rainfall through time at CSP (Spring). 

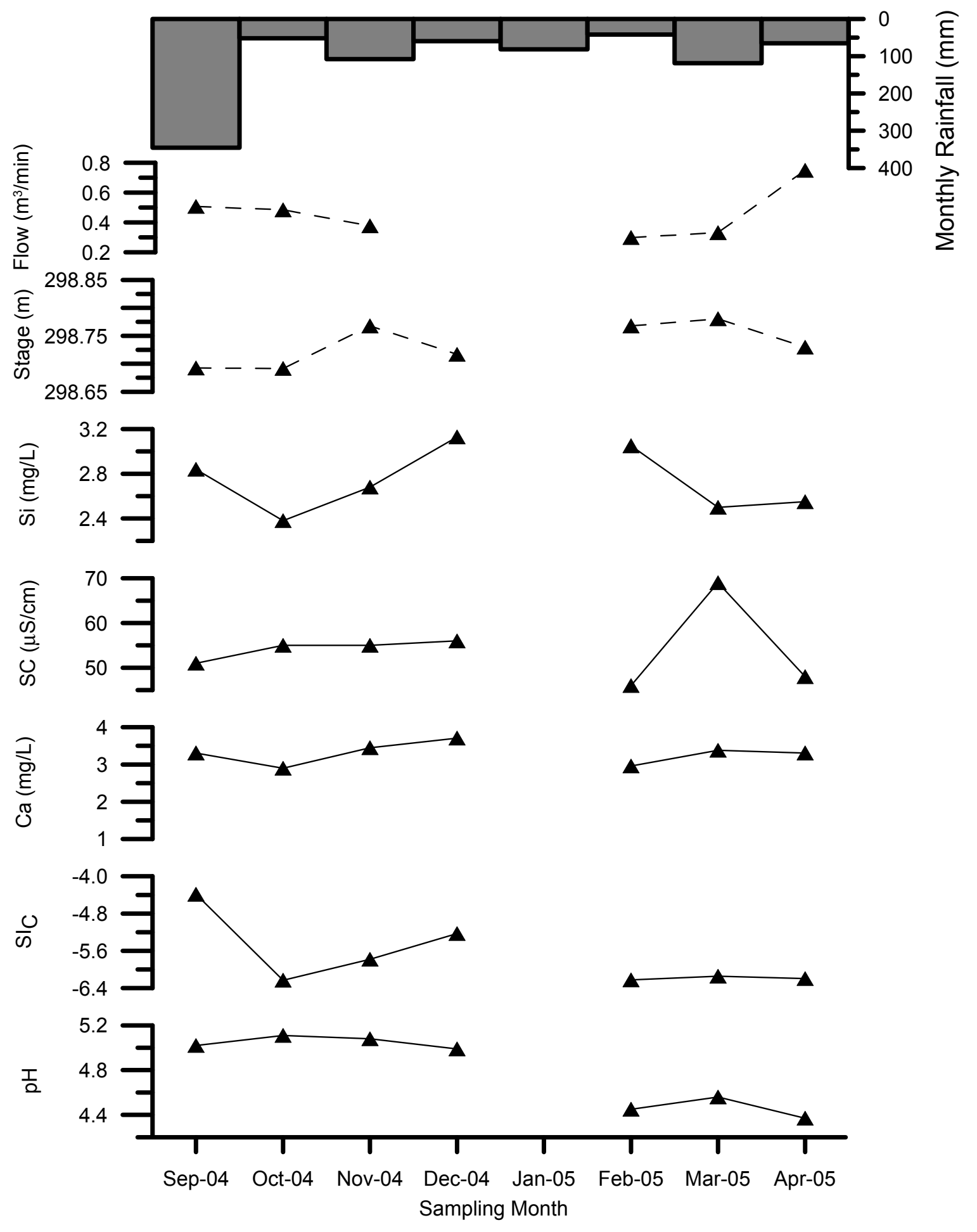

Figure 12: Chemical parameters, stage, flow, and rainfall through time at MTN (Spring). 


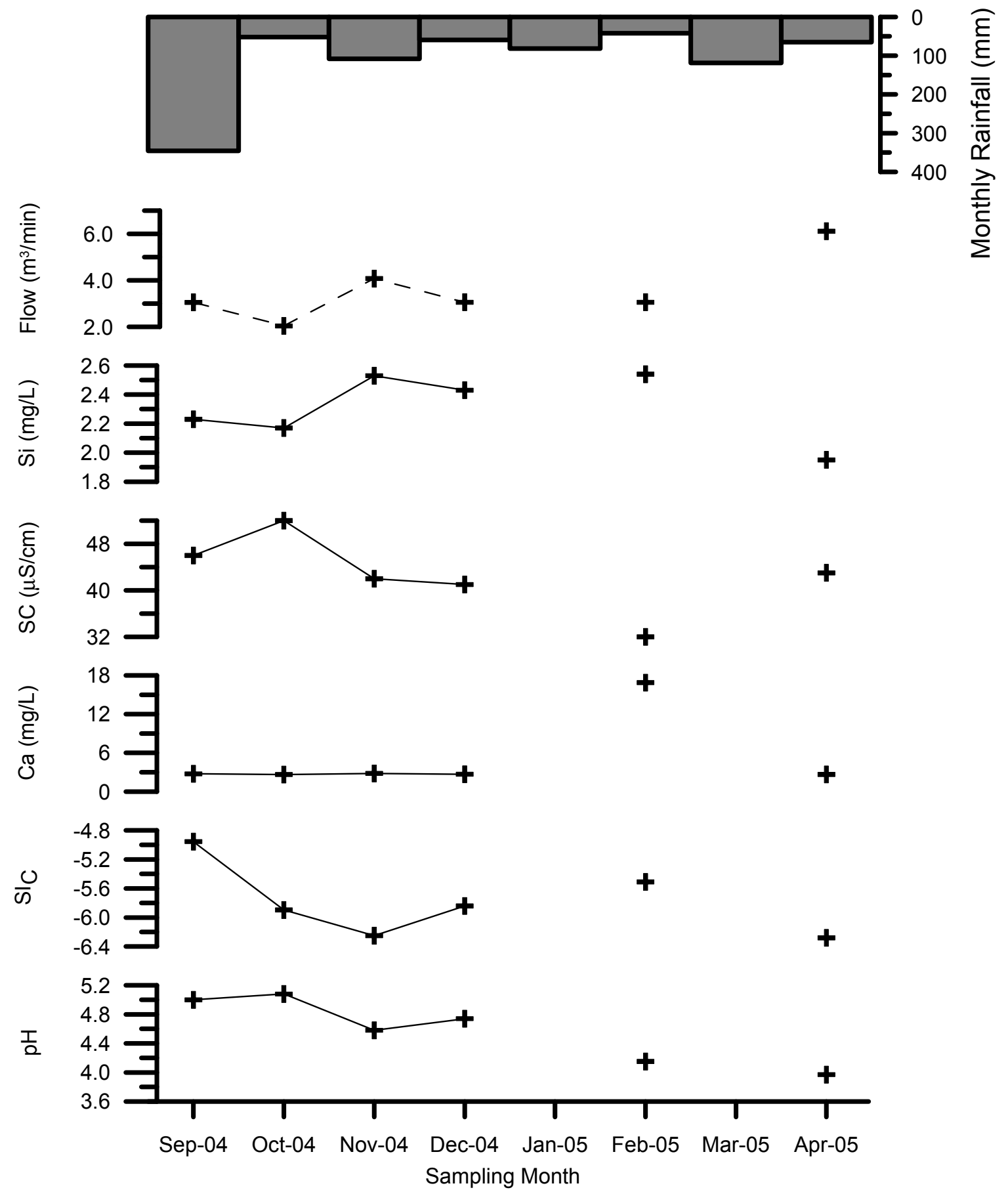

Figure 13: Chemical parameters, flow, and rainfall through time at $\mathrm{HGH}$ (Spring). 


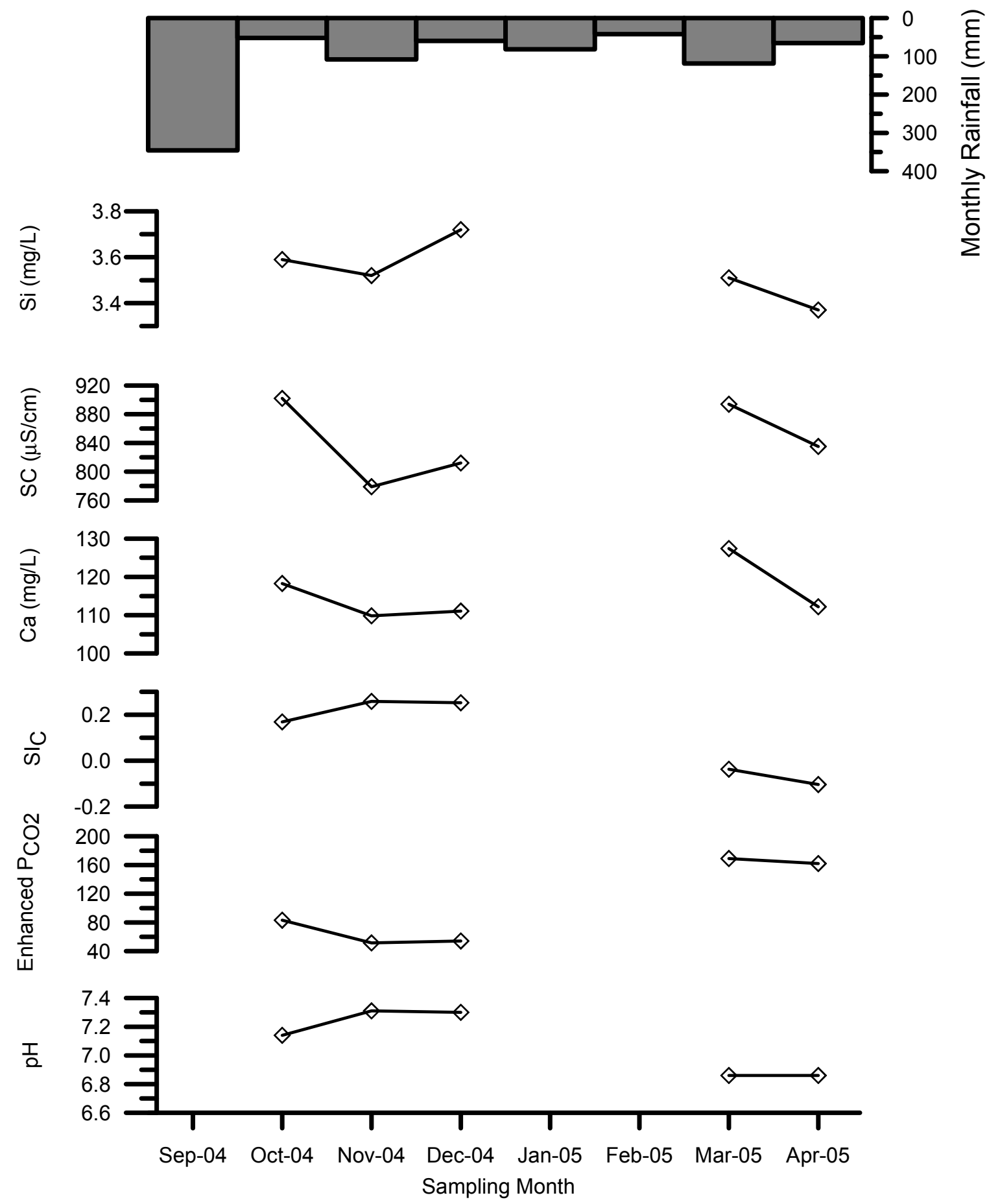

Figure 14: Chemical parameters and rainfall through time at STR (Well). 

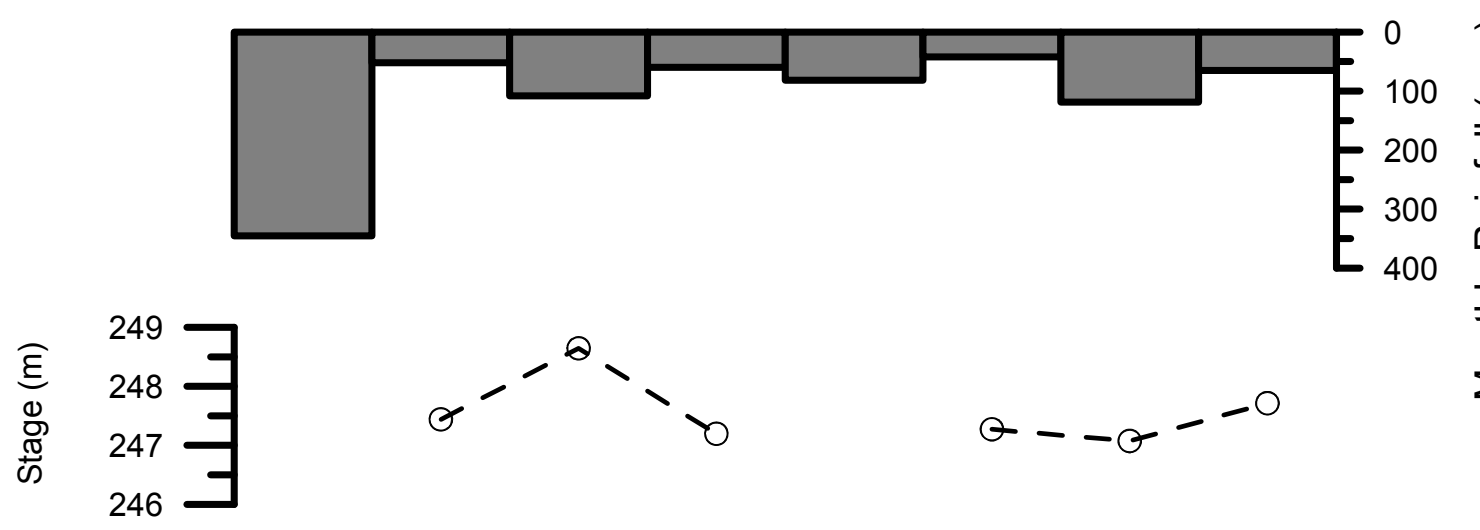

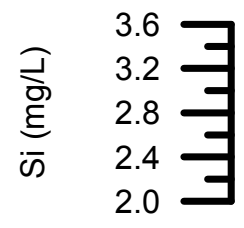
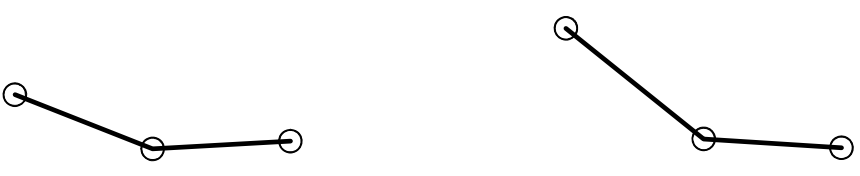

$\left.\begin{array}{ll}\widehat{E} & 320 \\ \stackrel{0}{D} & 240 \\ \mathcal{E} & \end{array}\right]$
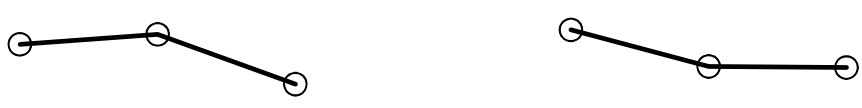

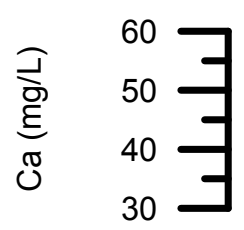

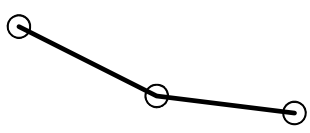

$\begin{array}{lll} & -1.6 \\ \omega & -2.0 \\ & -2.4 & \end{array}$
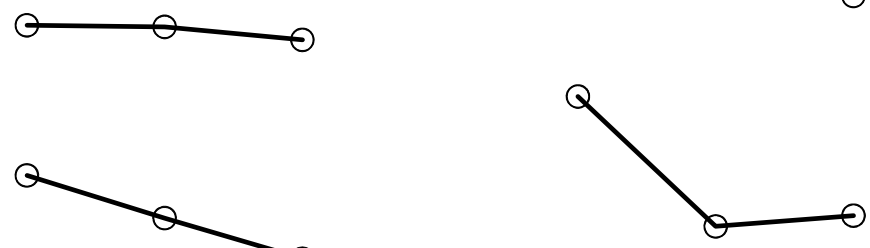

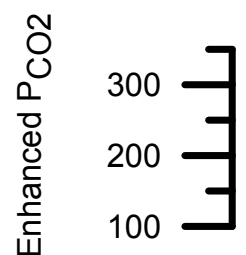
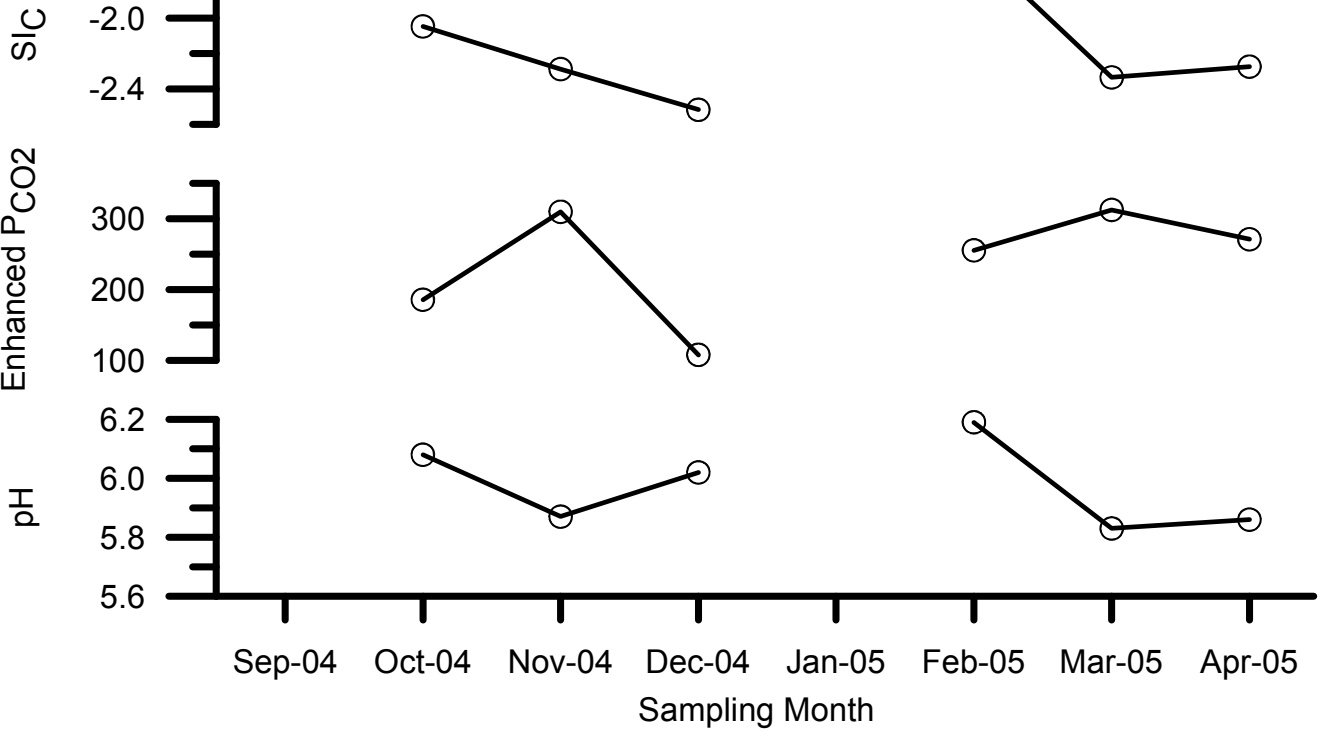

Figure 15: Chemical parameters, stage, and rainfall through time at MYR (Well). 


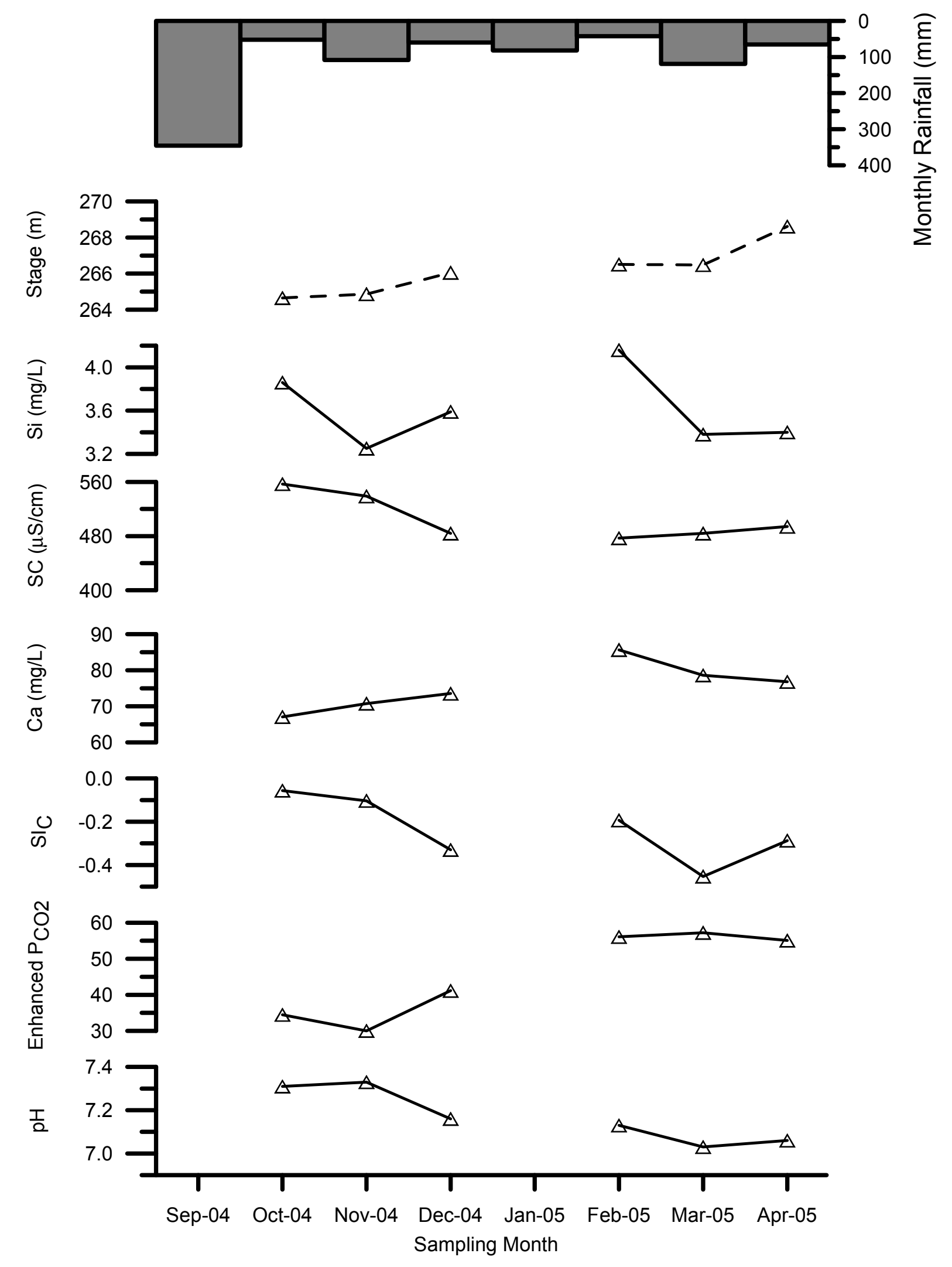

Figure 16: Chemical parameters, stage, and rainfall through time at BZK (Well). 

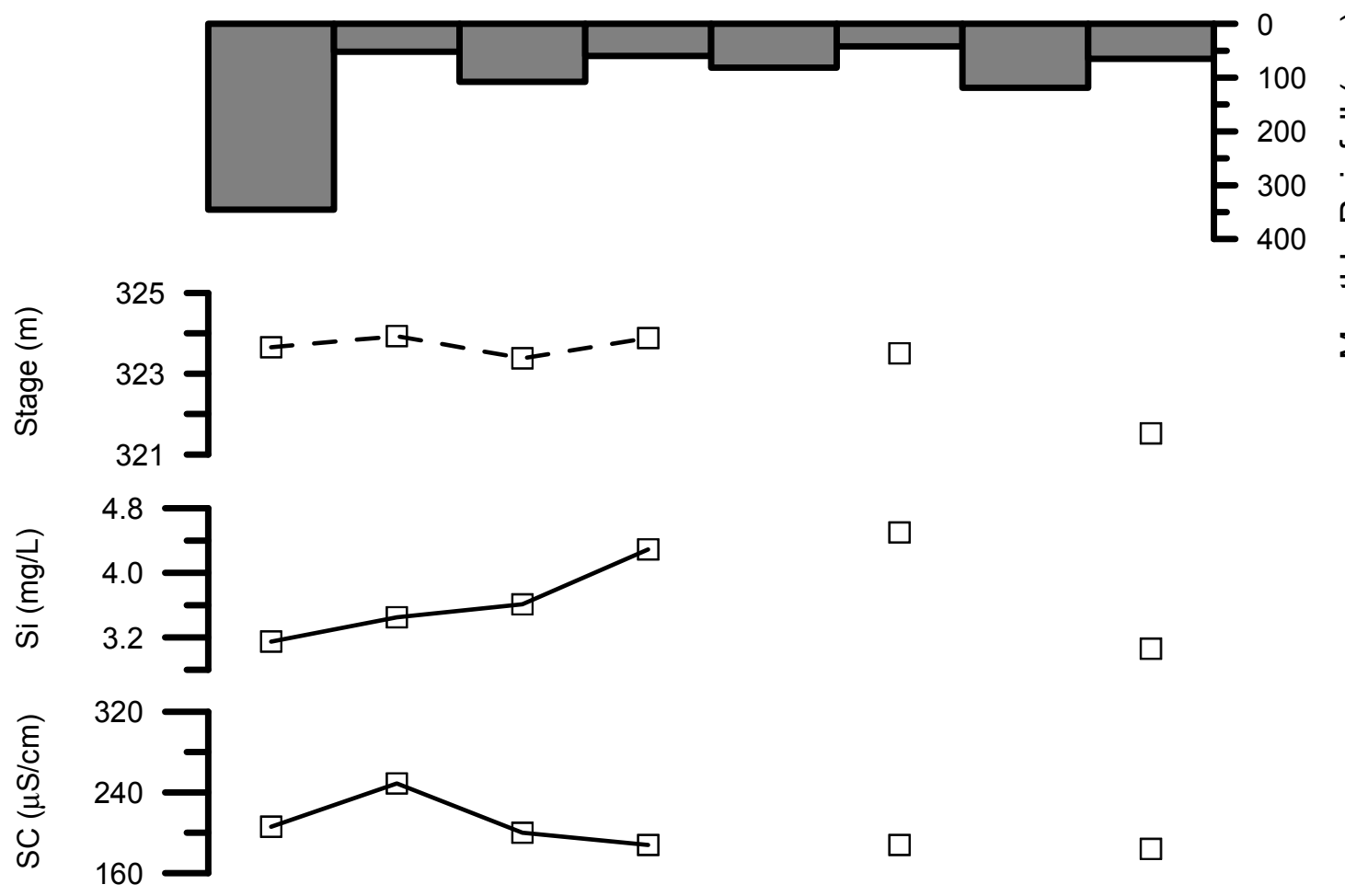

$\square$

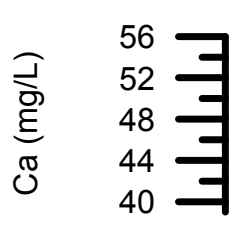

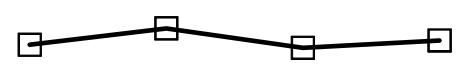

$\square$
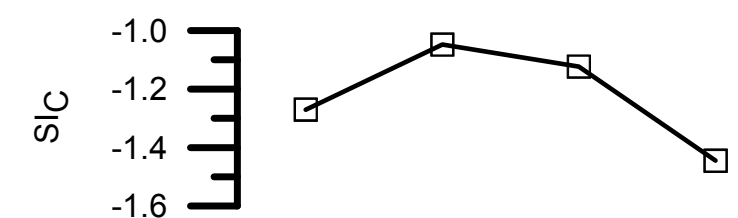

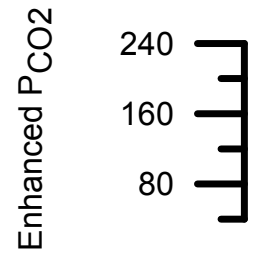
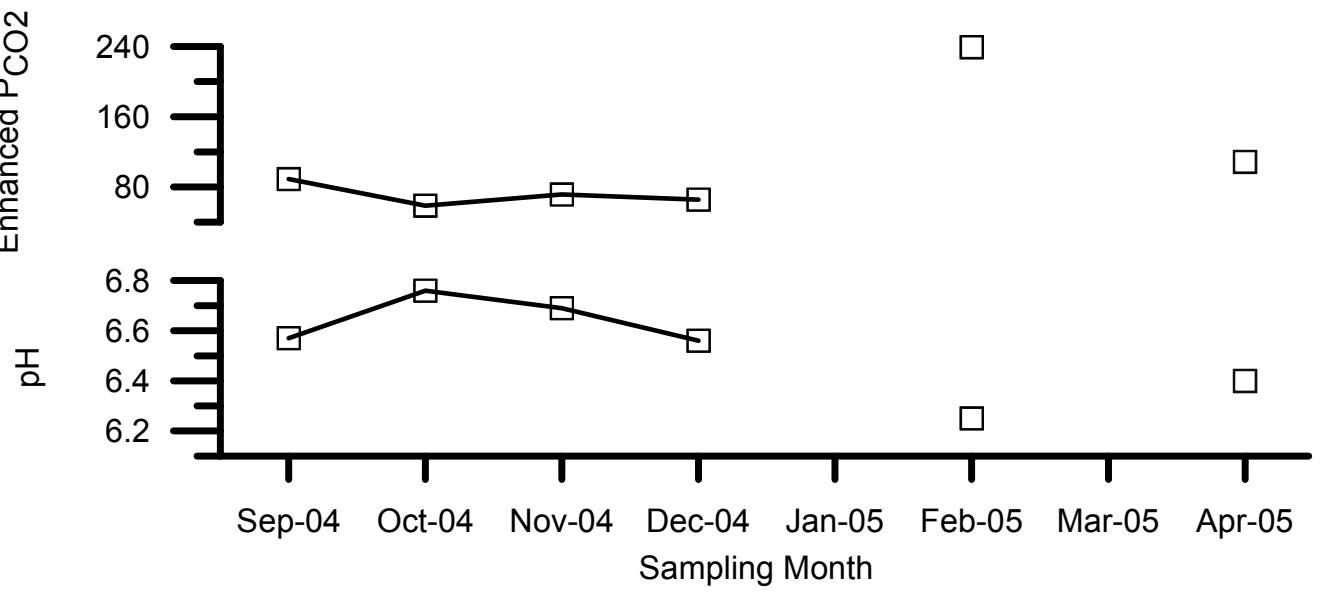

Figure 17: Chemical parameters, stage, and rainfall through time at YST (Well). 


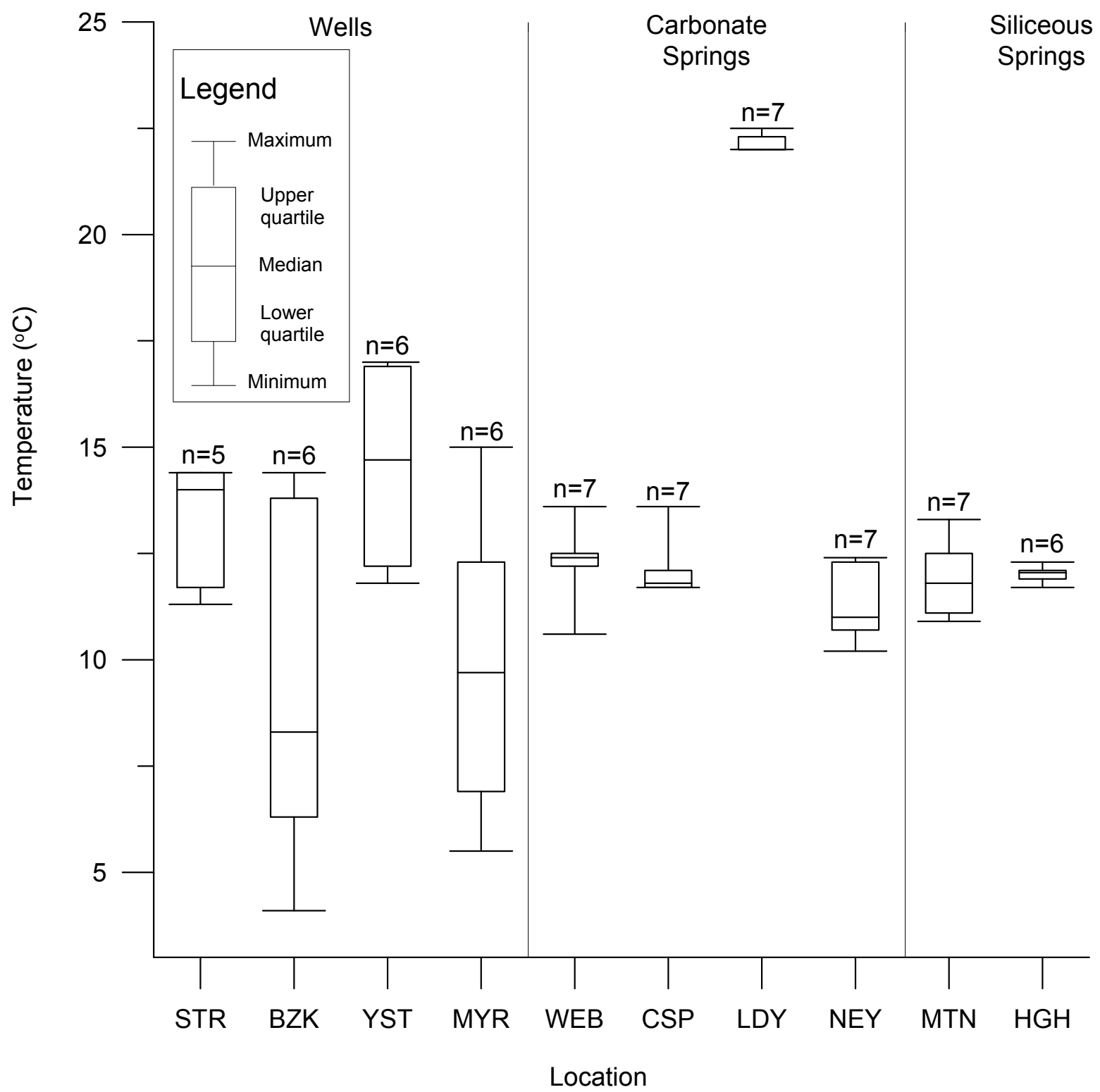

Figure 18: Temperature differences among sites. The above legend provides an explanation for the box and whisker plot and is the same for all plots of this type. 
(a)
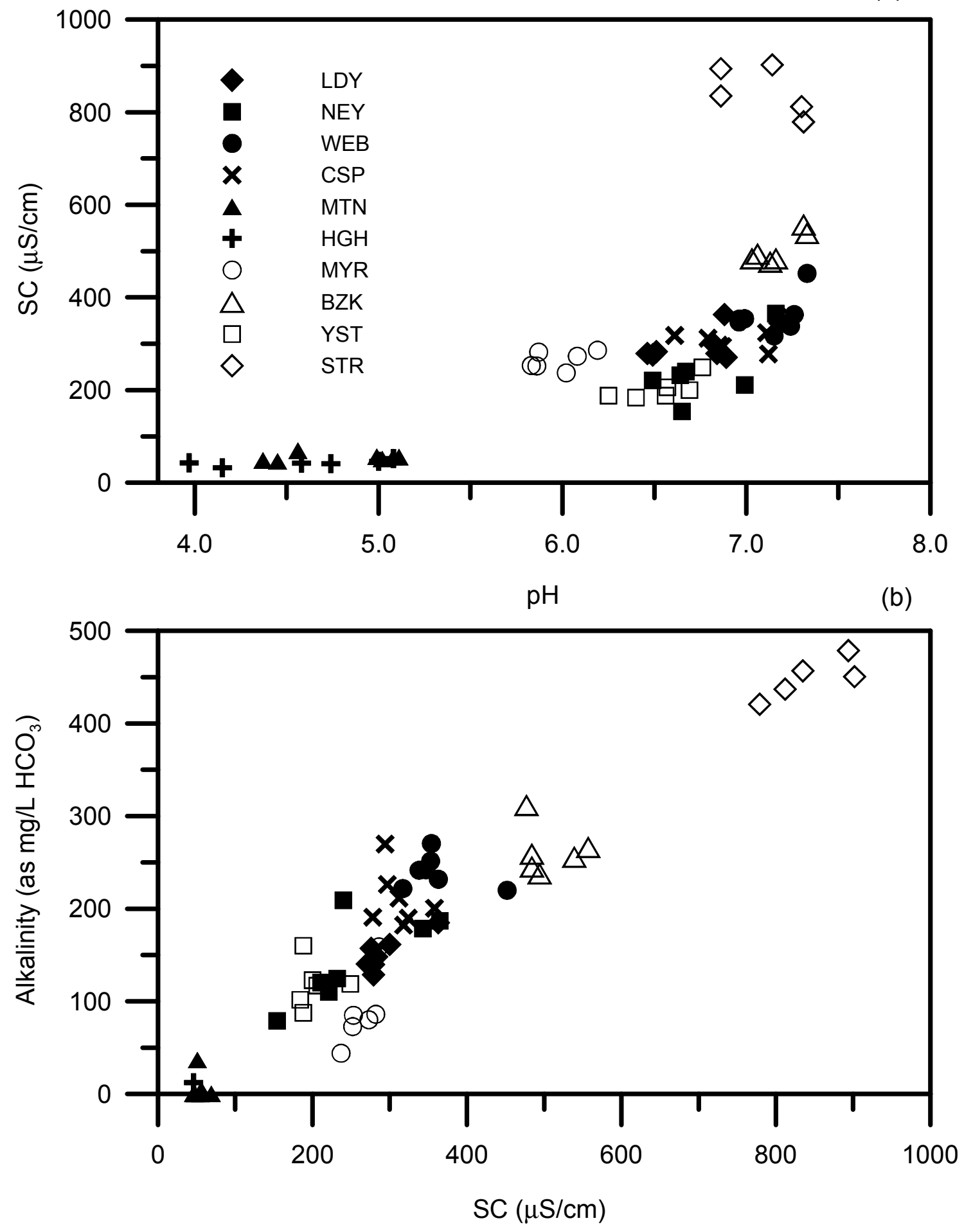

Figure 19: (a) pH vs. SC (b) SC vs. alkalinity at all locations.

Note: Wells have open symbols. Springs have closed symbols. 


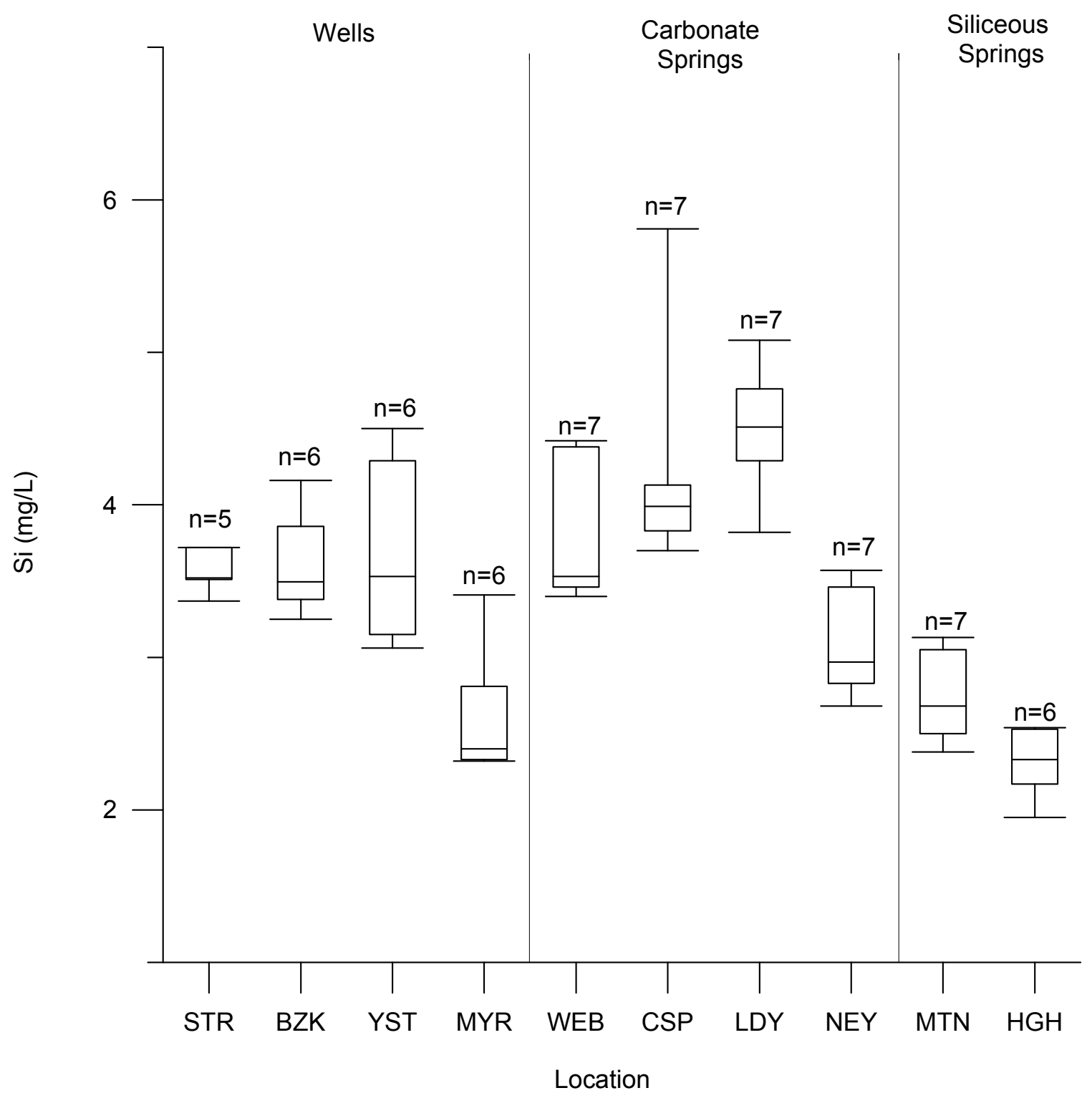

Figure 20: Box and whisker plots of silicon concentration at all sites. 


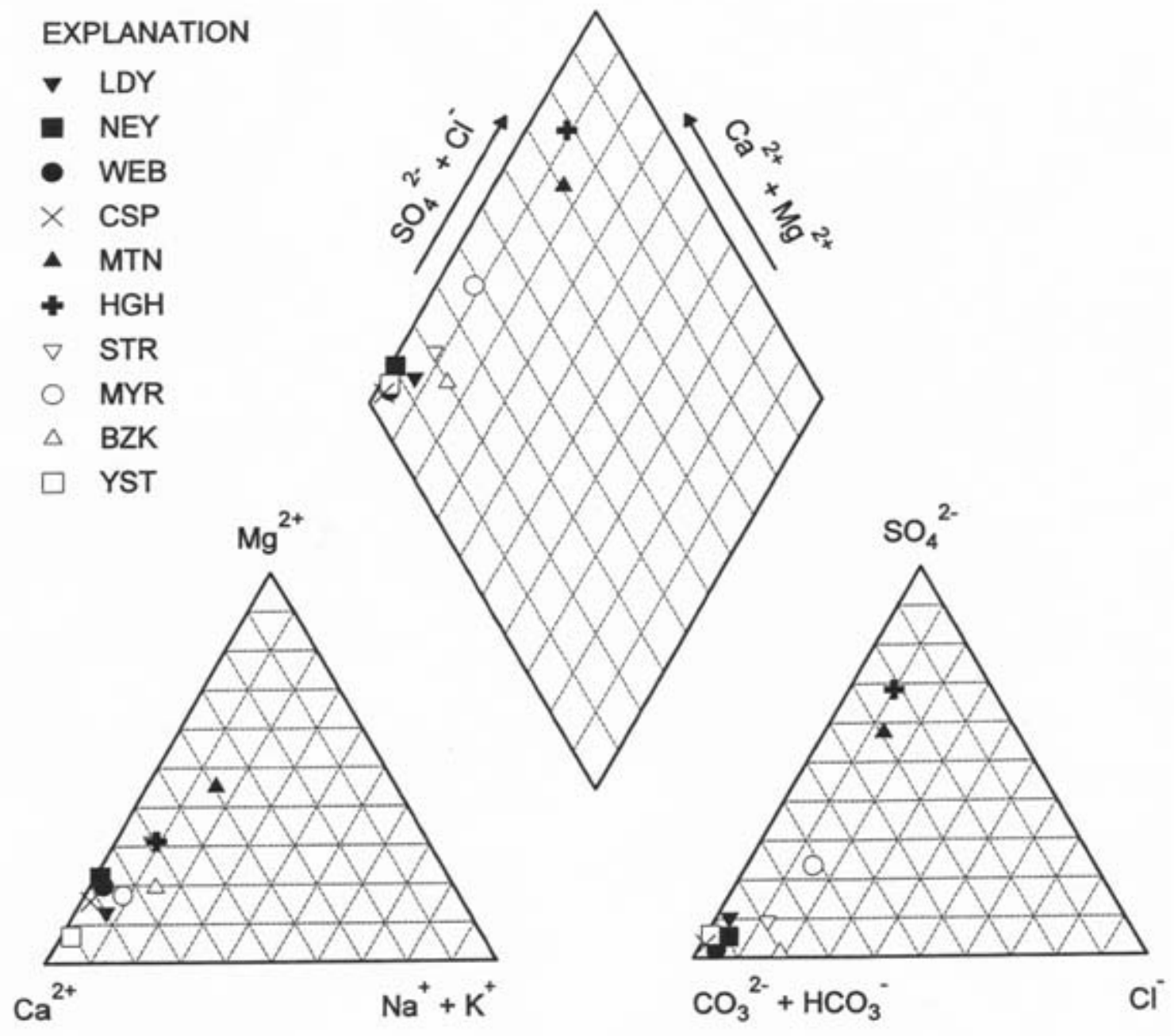

Figure 21: Piper diagram of all wells and springs in temporal study. 
between the cations $\mathrm{Ca}, \mathrm{Mg}$, and $\mathrm{Na}$ plus potassium $(\mathrm{K})$. The anions are dominated by bicarbonate except for anions in waters from springs MTN and HGH. These springs are of the $\mathrm{SO}_{4}$-type. Spring and well waters dominated by the bicarbonate anion also have high pHs and SCs.

SWLs were collected at four wells 2-6 times over a six month period following the synoptic well survey. SWLs differed by nearly six meters in some instances; however, the elevations of the water surface at these locations remained constant relative to each other (Figure 22).

\subsection{ANALYSIS OF RESULTS}

\subsubsection{Potentiometric surface}

The illustration of the potentiometric surface (Figure 7) is from Donovan et al. (2006) and has been modified to highlight a few important inferences drawn from the map. The primary conclusions are summarized herein. The potentiometric surface indicates that there are two regional directions of ground water flow in Cold Run Valley, with an inferred ground water divide between Sir Johns Run and Rock Gap Run (Figure 7). These streams capture surface flow from tributaries on the eastern side of Cacapon Mountain and ground water flow from the underlying ground water basin (Donovan et al. 2006). Two ridges, Cacapon Mountain and Warm Spring Ridge, act as topographic divides for surface water, thereby forming a drainage basin or catchment within Cold Run Valley. This interpretation is enhanced by topographic maps, particularly the location of surface water flow and water gaps in the ridge.

The potentiometric surface is a subdued reflection of topography; the highest hydraulic heads were found on the ridges and the lowest hydraulic heads were found in the valley. The northward decrease in potentiometric head that occurred on the northern side of the ground water divide illustrates the flow of ground water and surface water to the north. 


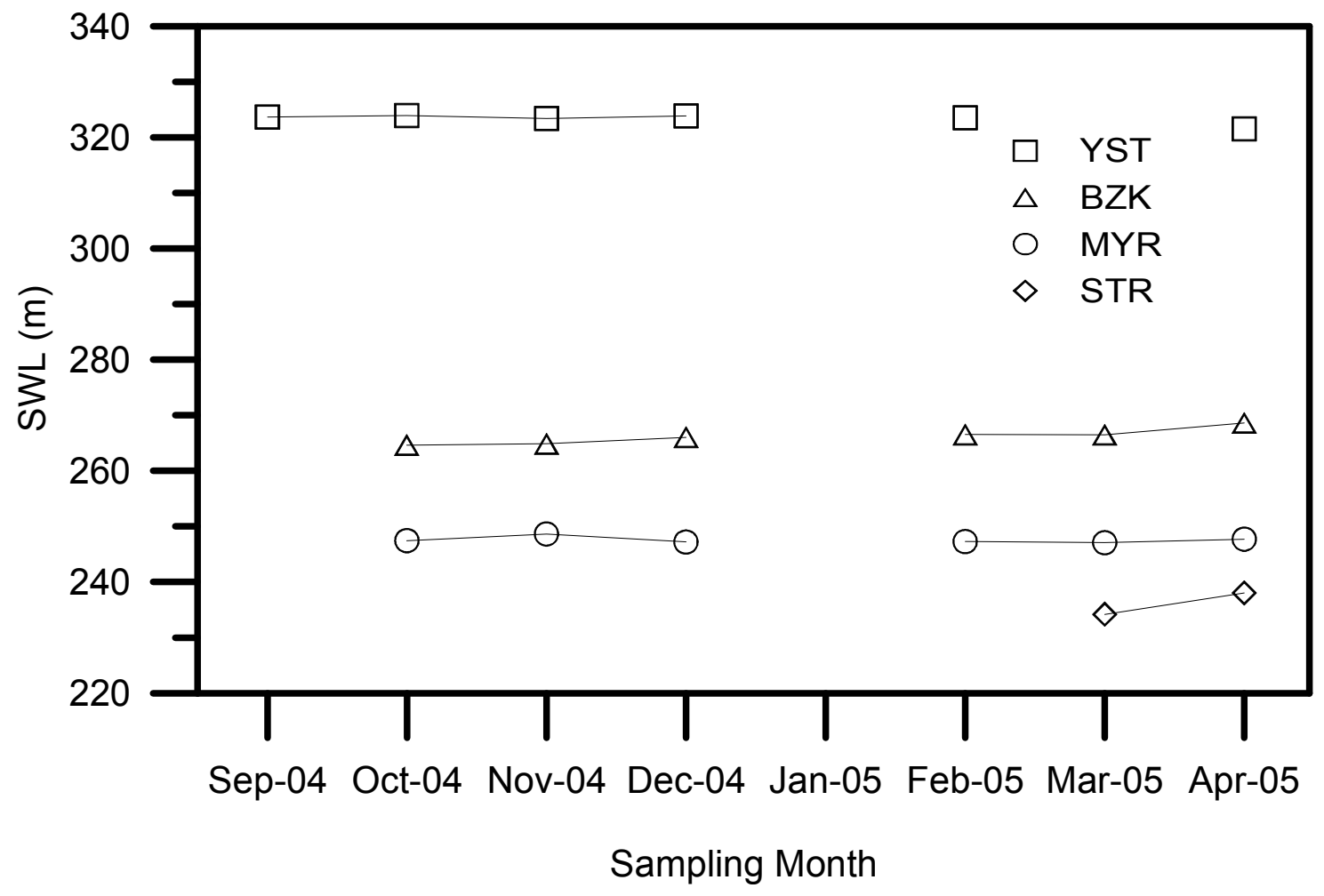

Figure 22: Static water level (SWL) through time in meters above mean sea level for wells in the temporal study. 
Sir Johns Run captures drainage from both Cacapon Mountain and Warm Spring Ridge and carries it northward where it is discharged into the Potomac River. Areas of recharge occur west of Sir Johns Run on Cacapon Mountain and east of Sir Johns Run on Warm Spring Ridge.

Tributaries south of the ground water divide up to the eastern boundary of Cacapon State Park flow northerly and southerly into Rock Gap Run. This stream then drains into Sleepy Creek. Within the central portion of Cacapon State Park, tributaries and streams drain into Indian Run and then into Sleepy Creek.

Regional flow occurs in a cross-strike direction toward Sleepy Creek and is clearly related to topography. Gaps in Warm Spring Ridge occurring at Rock Gap and Cacapon State Park allow the water to be transmitted in a cross-strike, easterly direction. Surface water in the study area is ultimately transmitted to the north, via Sir Johns Run, or to the east via tributaries to Sleepy Creek.

\subsubsection{Derived geochemical parameters}

$\mathrm{Ca} / \mathrm{Mg}$ molar ratios ranged from 0.81 to 15.83 and were used to separate springs and wells into potential water sources (Appendix Table A-8). CSP and LDY springs' waters had median $\mathrm{Ca} / \mathrm{Mg}$ molar ratios of approximately five and six (Figure 23). NEY spring's and BZK well's waters had ratios between three and four, and WEB spring's and MYR well's waters had ratios of approximately four. Well water from YST had a median Ca/Mg molar ratio of about 13. Although these ratios are all indicative of a carbonate source, YST appears to have a different water source than the other springs and wells.

The high $\mathrm{Ca} / \mathrm{Mg}$ molar ratio in water from YST well indicates that its water comes from a relatively pure limestone. No dolomitic beds have been mapped in the Clinton 


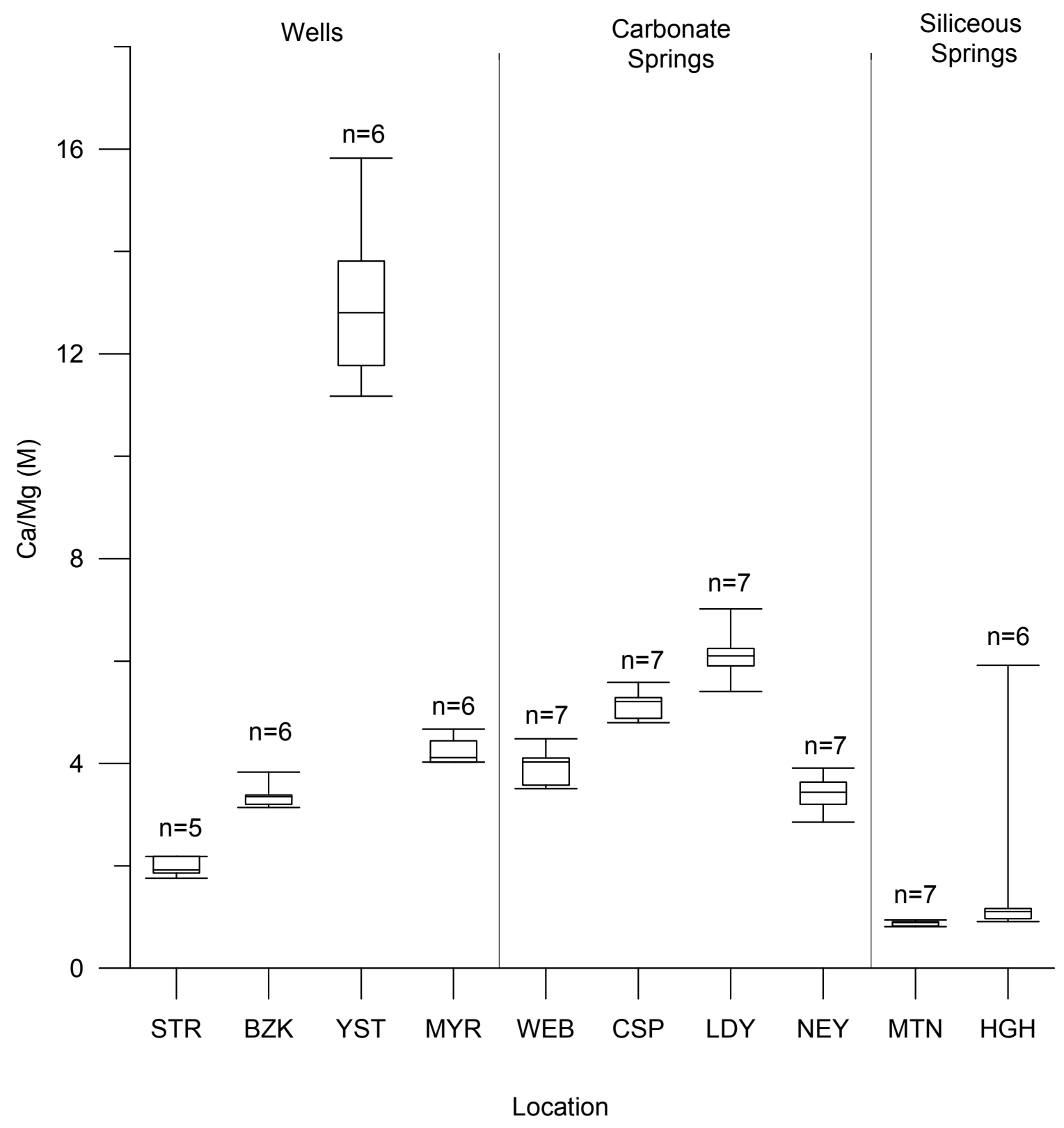

Figure 23: Box and whisker plots of calcium to magnesium molar ratio at all sites. 
Group/McKenzie Formation where YST well is likely completed. The comparatively high Fe content and limestone signature of the water suggests that it was completed in this unit. Shaley sandstone, sandstone, shale, and shaley limestone comprise the formation (Price and Ludlum 1951).

Water from STR well had a low median Ca/Mg molar ratio of approximately two, high Ca concentrations, and high $\mathrm{pH}$ values suggesting probable contact with dolomite. This well could have been completed in a limestone unit like the Tonoloway or Wills Creek formations with dolomitic beds.

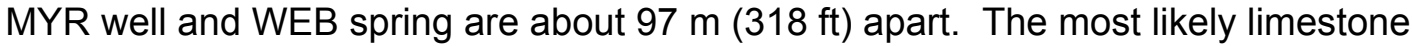
sources for the springs in the similar valley setting and BZK and MYR wells are the Wills Creek and Tonoloway formations. For LDY spring, the Helderberg Group and the Wills Creek and Tonoloway formations are possible sources. However, calcite cements the porous Oriskany Formation of the Helderberg Group; so this formation is also a potential source, even though it is mapped as sandstone, not carbonate (Diecchio et al. 1984; Heald et al. 1962). In some locations, the Oriskany Formation grades into limestone.

MTN and HGH spring waters had low $\mathrm{Ca}$ and Mg concentrations, low pHs, and the lowest median $\mathrm{Ca} / \mathrm{Mg}$ molar ratios of approximately one, indicating siliceous sources. Here, siliceous is used to refer to source rocks that do not contain high concentrations of siliceous minerals but are comprised primarily of non-carbonate minerals. Unlike the other springs, they are located at topographic highs along Cacapon Mountain. Given the surface geology where the springs issue, MTN's source is likely the Clinton Group/McKenzie Formation, while HGH's is likely the Tuscarora sandstone.

All locations had waters with $\mathrm{P}_{\mathrm{CO} 2}$ concentrations much greater than atmospheric concentration (Figure 24). Of these sites, waters from BZK and WEB wells had the lowest $\mathrm{P}_{\mathrm{CO} 2}$ concentrations, and waters from STR well, LDY spring, and YST well had the highest 


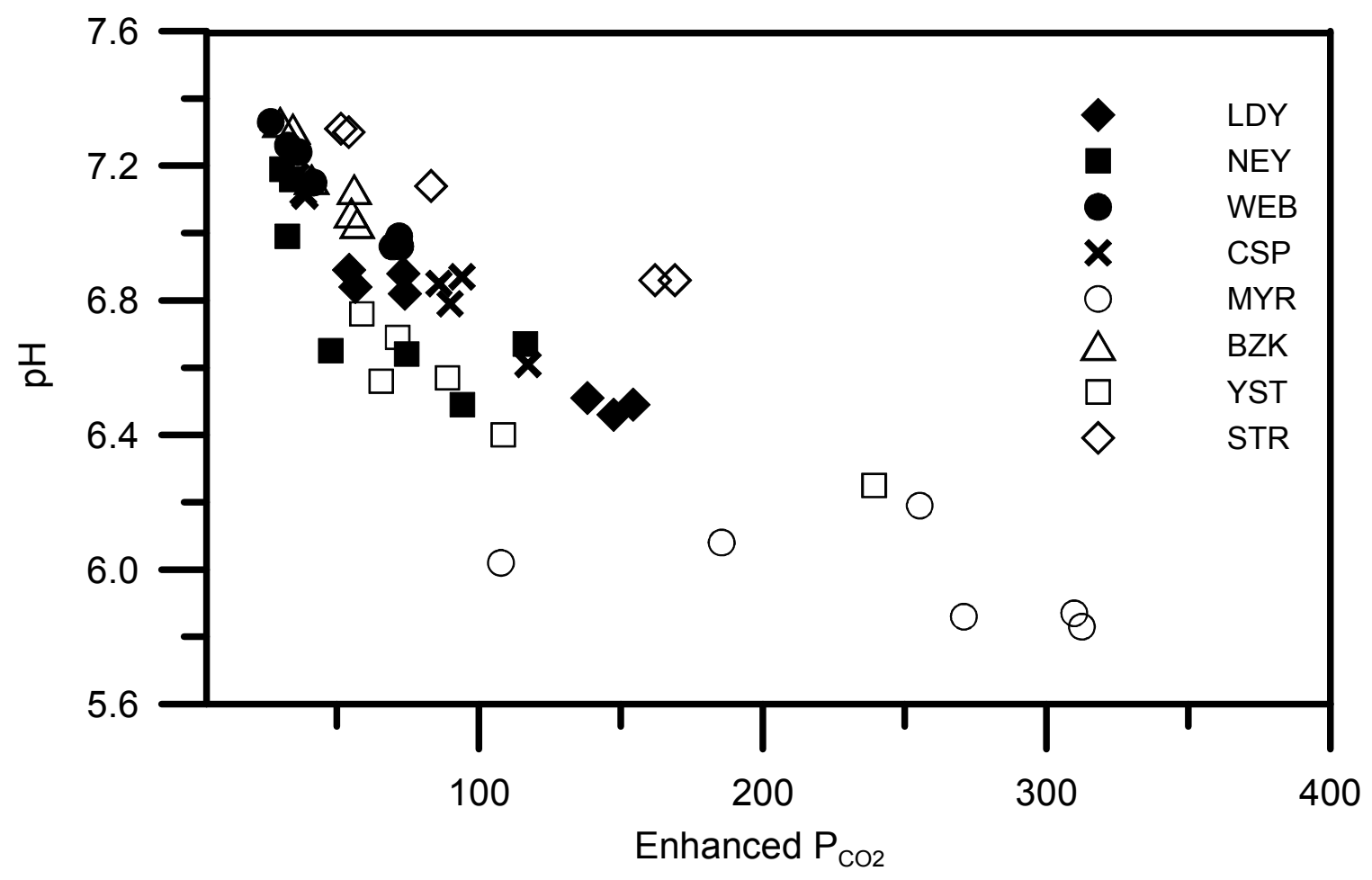

Figure 24: Enhanced $\mathrm{P}_{\mathrm{CO} 2}$ vs. $\mathrm{pH}$ at all locations but siliceous springs.

Note: Wells have open symbols. Springs have closed symbols. 
concentrations, after water from MYR well. The $\mathrm{P}_{\mathrm{CO} 2}$ is not reported for MTN and HGH spring waters, because their low alkalinities limited the accuracy of the $\mathrm{CO}_{2}$ calculation.

WEB and NEY spring waters and CSP and LDY spring waters had median enhanced $\mathrm{P}_{\mathrm{CO} 2 \mathrm{~s}}$ of less than 50 and 50-100 times greater than atmospheric concentration, respectively. WEB and NEY are in similar settings. Both are in pasture farm land in the carbonate valley. CSP is located in a forested area with abundant plant life. LDY lies at the base of Warm Spring Ridge. Here, the ridge is covered with trees, but the area immediately surrounding the spring is not. These springs all have the potential for $\mathrm{P}_{\mathrm{CO} 2}$ to be above that of the atmosphere given the overlying soil and plant life; however, other factors like the recharge area and flowpath length are also important and were not determined in this research. Therefore, the interpretation based on $\mathrm{P}_{\mathrm{CO} 2}$ is mostly speculative.

Several distinctions among locations are evident when comparing the relationship of enhanced $\mathrm{P}_{\mathrm{CO} 2}$ to the $\mathrm{Ca} / \mathrm{Mg}$ molar ratio (Figure 25). Springs are chemically more closely related regarding these parameters than are wells. WEB spring and BZK wells have noticeable graphical overlap for these parameters and are likely from the same carbonate source. Waters from LDY spring and STR well had similar enhanced $\mathrm{P}_{\mathrm{CO} 2 \mathrm{~s}}$ but very different $\mathrm{Ca} / \mathrm{Mg}$ molar ratios. They are probably not from the same source of rock or combination of rock sources.

Nearly identical relationships among sites are shown graphically for $\mathrm{SI}_{\mathrm{C}}$ and $\mathrm{SI}$ (Figure 26). STR well is the only site with water whose median indicates that it is oversaturated with calcite. BZK well water is the next nearest to saturation, followed by waters from WEB and CSP springs. MTN and HGH springs' waters have larger ranges for $\mathrm{SI}_{\mathrm{C}}$ like NEY spring. All sites are less saturated with dolomite than they are for calcite. All sites are oversaturated with quartz. 


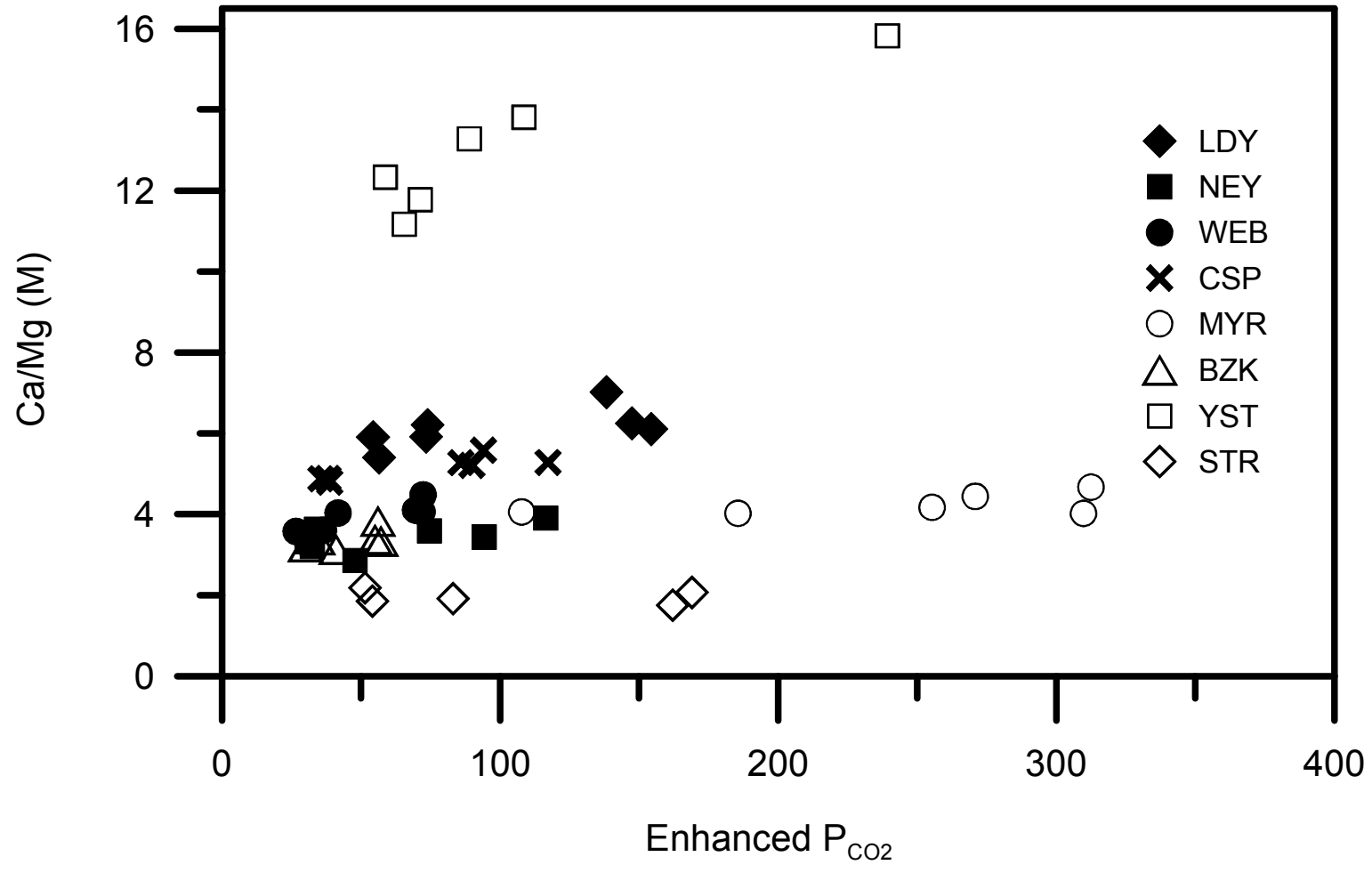

Figure 25: Calcium to magnesium molar ratio vs. enhanced $\mathrm{P}_{\mathrm{CO}}$. 


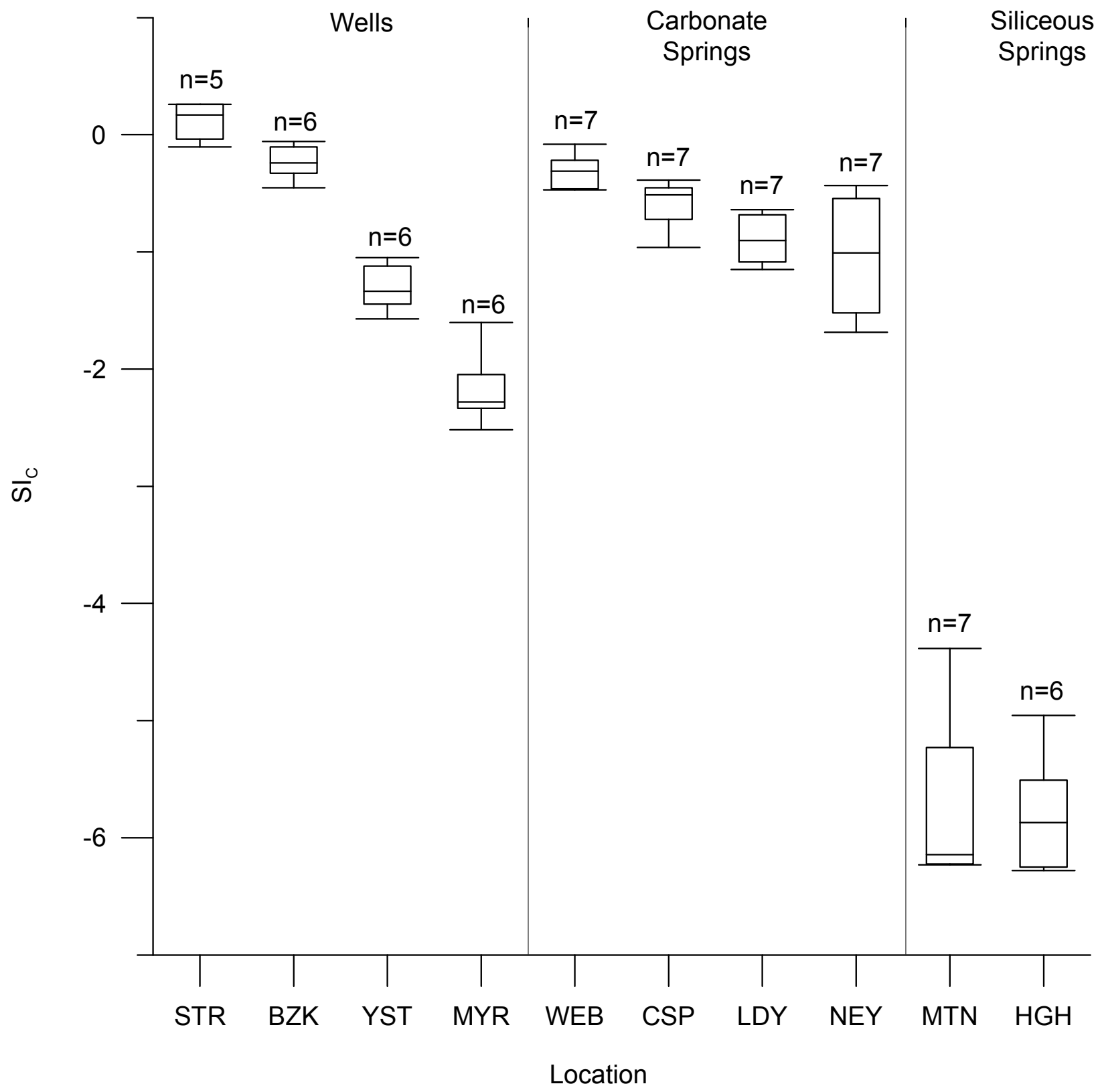

Figure 26: Box and whisker plots of the calcite saturation index at all sites. 


\subsubsection{Relationships between chemical parameters}

PCA was completed using multiple strategies for the first four rounds of data. The last three rounds were excluded due to problems with the $\mathrm{pH}$ meter. No data were excluded from these first four rounds except for concentrations below the detection limit. A PCA was performed on spring and well data together and each set separately (Table 4). In all cases, the first two components have eigenvalues greater than 1 and are the focus of the discussion. For springs and wells together, the cumulative variation given by the first two principal components is $80.8 \%$ (Table 4). The variables with the highest loadings on PC1 are $\mathrm{pH}, \mathrm{SC}, \mathrm{Ca}, \mathrm{Mg}, \mathrm{Na}$, and alkalinity. The PC1 has a high eigenvalue $(>5)$ in all analyses run, indicating that this set of variables strongly defines the overall water chemistry. This component is termed the carbonate component because it reflects the chemistry of carbonate rock dissolution. Calcium concentrations are closely related to the PC1 sample scores (Figure 27).

PC2 is more variable among the three data sets than is PC1. This component is termed the non-carbonate component. $\mathrm{SO}_{4}$ and $\mathrm{Si}$ were found to be among the most important variables to PC2 for all PCAs completed. The results of the PCA for wells are nearly identical to the results of the PCA with wells and springs combined. Wells and springs differ in that $\mathrm{K}$ had a high loading on PC2 for the wells-only PCA, and Na had a high loading for the springs-only PCA. Waters from STR and BZK wells had very high $\mathrm{Na}$ concentrations, and water from MYR well had higher $\mathrm{K}$ concentrations relative to the other wells and springs. LDY spring's waters had the highest $\mathrm{SO}_{4}$ concentrations among the springs, followed by non-carbonate spring waters HGH and MTN.

When the PC1 and PC2 scores are plotted against each other, two groups of springs become apparent (Figure 28). The two siliceous springs, MTN and HGH, group together graphically, and the four carbonate springs group together. LDY spring plots with the 
Table 4: Summary of three PCAs

\begin{tabular}{ccc|cc|cc}
\hline & \multicolumn{2}{c|}{ Springs and Wells } & \multicolumn{2}{c|}{ Springs } & \multicolumn{2}{c}{ Wells } \\
& $\mathrm{PC} 1$ & $\mathrm{PC} 2$ & $\mathrm{PC} 1$ & $\mathrm{PC} 2$ & $\mathrm{PC} 1$ & $\mathrm{PC2}$ \\
\hline $\mathrm{pH}$ & $\mathbf{0 . 3 2 5}$ & $\mathbf{- 0 . 3 4 4}$ & $\mathbf{0 . 4 0 7}$ & -0.043 & $\mathbf{0 . 3 5 5}$ & 0.294 \\
$\mathrm{SC}$ & $\mathbf{0 . 4 1 9}$ & 0.062 & $\mathbf{0 . 4 1 1}$ & -0.035 & $\mathbf{0 . 3 8 8}$ & -0.182 \\
$\mathrm{HCO}_{3}$ & $\mathbf{0 . 4 1 5}$ & -0.079 & $\mathbf{0 . 4 0 8}$ & -0.107 & $\mathbf{0 . 4 0 0}$ & -0.064 \\
$\mathrm{Ca}$ & $\mathbf{0 . 4 1 3}$ & -0.040 & $\mathbf{0 . 3 9 2}$ & 0.023 & $\mathbf{0 . 4 0 1}$ & -0.059 \\
$\mathrm{Mg}$ & $\mathbf{0 . 3 9 2}$ & 0.188 & $\mathbf{0 . 3 7 6}$ & -0.240 & $\mathbf{0 . 3 8 4}$ & -0.204 \\
$\mathrm{Na}$ & $\mathbf{0 . 3 5 1}$ & 0.165 & 0.264 & $\mathbf{0 . 4 9 7}$ & $\mathbf{0 . 3 5 7}$ & -0.050 \\
$\mathrm{SO}_{4}$ & 0.224 & $\mathbf{0 . 5 6 4}$ & -0.160 & $\mathbf{0 . 6 8 9}$ & 0.196 & $\mathbf{- 0 . 5 4 0}$ \\
$\mathrm{K}$ & -0.039 & $\mathbf{0 . 5 2 0}$ & 0.012 & 0.203 & -0.214 & $\mathbf{- 0 . 5 4 5}$ \\
$\mathrm{Si}$ & 0.219 & $\mathbf{- 0 . 4 6 8}$ & $\mathbf{0 . 3 2 9}$ & $\mathbf{0 . 4 0 6}$ & 0.207 & $\mathbf{0 . 4 9 0}$ \\
\hline Eigenvalues & 5.53 & 1.74 & 5.67 & 1.65 & 6.13 & 2.12 \\
Proportion of Variance & 0.615 & 0.194 & 0.630 & 0.184 & 0.681 & 0.235 \\
\hline Only eigenvalues greater than 1 are reported; Loadings greater than \pm 0.3 are in bold.
\end{tabular}




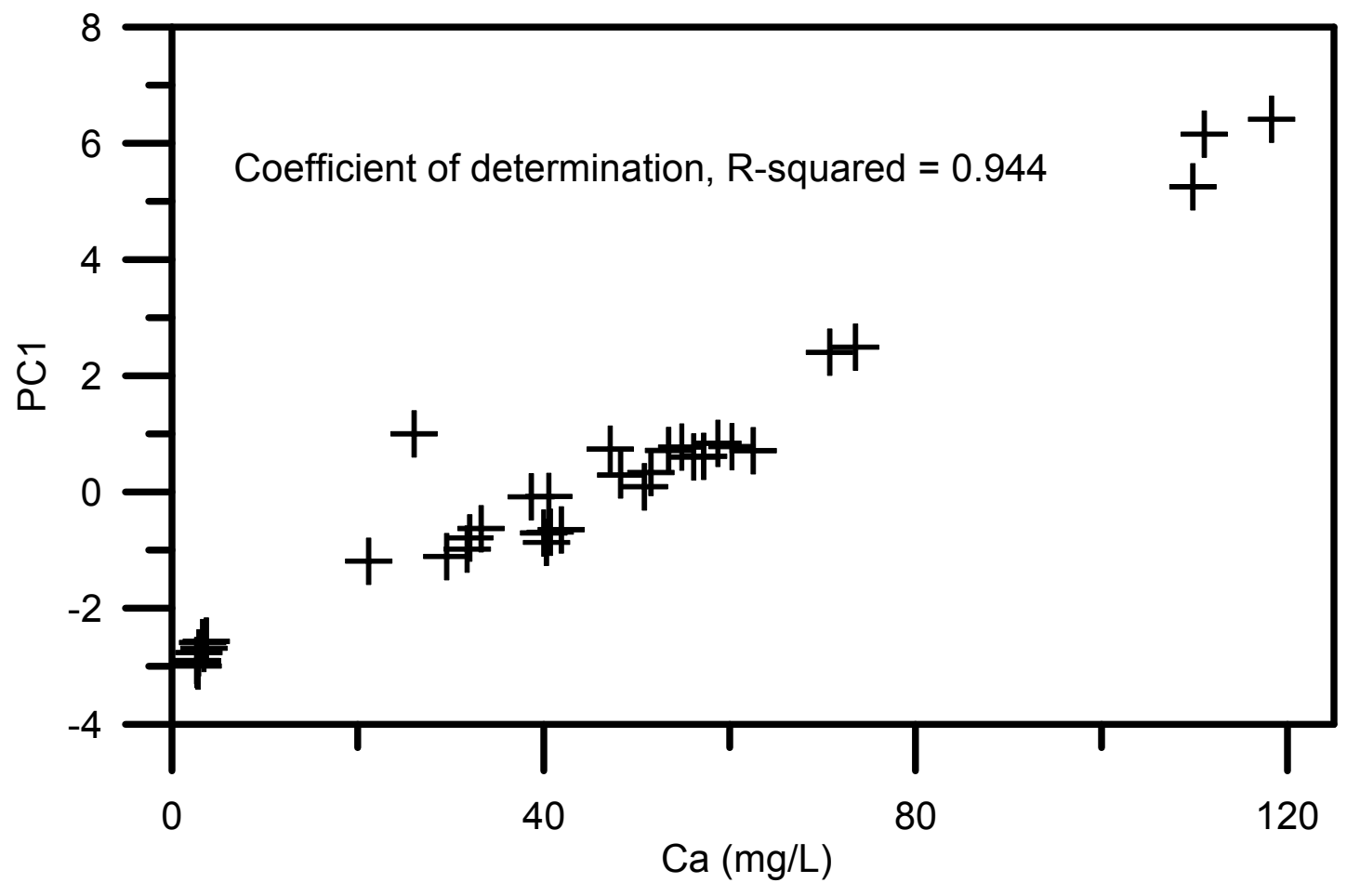

Figure 27: PC1 scores vs. Ca concentration for all locations. 


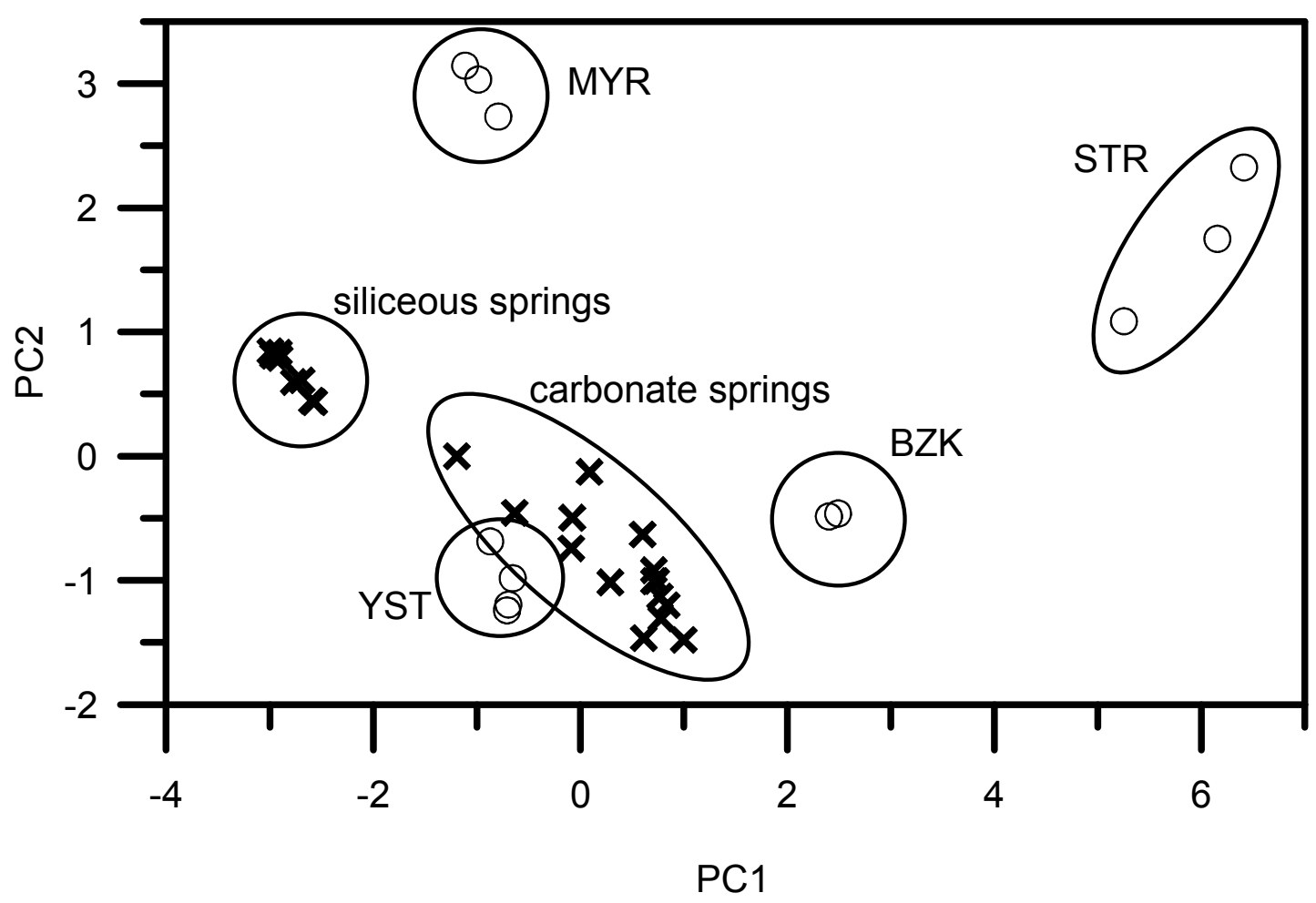

Figure 28: PC1 scores vs. PC2 scores for all locations. 
carbonate springs due to chemical similarities. The carbonate springs load higher on PC1, the carbonate component, while the siliceous springs load higher on PC2, the noncarbonate component. This finding shows that there are two well-defined spring types in the study area.

The wells are all distinct when comparing PC1 to PC2 (Figure 28). YST well is most similar to the carbonate springs based on this analysis. All wells load higher on PC1 than do the siliceous springs.

\subsubsection{Comparison of well and spring data}

Springs and wells were differentiated in several ways. The springs could be separated into two groups, those with high pHs, SCs, and alkalinities and those with low pHs, SCs, and alkalinities. These groups were termed carbonate and siliceous, respectively (Figures 19a and 19b). The concentration range for the carbonate springs fell within the larger range defined by the wells.

Differences in temperature are notable between wells and springs (Figure 18). Well waters were much more variable through time regarding temperature than were spring waters and had larger temperature ranges. Spring waters also contained lower concentrations of $\mathrm{Na}, \mathrm{Cl}$, and $\mathrm{SO}_{4}$ than did well waters, with the exception of $\mathrm{YST}$ well (Appendix Table A-6). These findings suggest that the wells in this study may have a more rapid interaction between surface conditions and ground water than do the wells.

Even if wells are completed in the same aquifer, they still may differ greatly as karst aquifers are typically heterogeneous. YST is the only location among the wells that may be receiving water from a different formation than the other wells, due to the water's relatively high $\mathrm{Ca} / \mathrm{Mg}$ molar ratio and Fe concentration. Although the other wells appear to be completed in the same formation, they are still unique chemically as the water quality in each well is indicative of very localized lithology. 
Unlike wells, the carbonate springs in this study do not receive water from one distinct point in the aquifer. Aside from strictly conduit-fed springs, springs discharge water from a larger portion of the aquifer than do wells. Springs are spatially integrative, while wells sample water from a localized point in an aquifer. This spatial averaging of water quality is evident for the springs in this research but not for the wells. 


\subsection{DISCUSSION}

Several factors were found to influence the direction of ground water flow and the hydrochemical facies of spring and well waters. The potentiometric surface reveals the importance of topography and structure to flow direction (Figure 7). Along the slopes of Cacapon Mountain, ground water was found to be transmitted in a down-dip direction, as given by the decreasing potentiometric contours. In the valley between Cacapon Mountain and Warm Spring Ridge, regional ground water flow may occur along strike. In similar settings, flow directions have been identified both along strike and along dip. Ground water movement along dip in the vadose zone has been observed in steeply dipping rocks (Ginsberg and Palmer 2002). In the phreatic zone, ground water was predominantly conducted along strike. Trapp and Horn (1997) have noted cross-strike ground water flow under ridges and flow parallel to strike in valleys in the Valley and Ridge Province. Burton et al. (2002) modeled ground water flow in the Valley and Ridge province and found that downdip flow was a controlling factor. In the Cacapon Mountain aquifer, the controlling flowpaths cannot be determined based on this project and are only speculative.

The springs selected for study lie in several topographic and geologic settings (Table 5): Spring group A discharges on the ridges or slopes where siliceous rocks are present at the surface; Spring group B discharges in the upper or lower valleys where carbonate rocks are present at the surface, and spring group $\mathrm{C}$ discharges at the base of a ridge where siliceous rocks are present at the surface.

As the PCA indicates, some of the springs have strong carbonate signatures that others lack (Table 4). The springs with carbonate signatures, whose variables load high on PC1, are located in the upper and lower valleys between Warm Spring Ridge and Cacapon Mountain (Group B) and at the eastern base of Warm Spring Ridge (Group C); these areas are underlain by the Tonoloway/Wills Creek formations and the Helderberg Group, respectively. Group $\mathrm{C}$ is near the contact of the Helderberg Group and the 
Table 5: Spring groups by chemistry, location, and speculative source.

\begin{tabular}{|c|c|c|c|c|c|}
\hline Group & Chemical Signature & PCA Result & Physical Location & $\begin{array}{l}\text { Interpreted Water } \\
\text { Source } \\
\end{array}$ & Springs \\
\hline A & $\begin{array}{c}\text { low } \mathrm{SC}, \mathrm{Ca} \text {, and } \mathrm{HCO}_{3} \\
\mathrm{pH}<5.2 ; \mathrm{T}<14^{\circ} \mathrm{C}\end{array}$ & loads higher on PC2 & $\begin{array}{c}\text { ridges, slopes; } \\
\text { elevations > 980' } \\
(299 \mathrm{~m})\end{array}$ & $\begin{array}{l}\text { siliciclastics, } \\
\text { shallow }\end{array}$ & $\begin{array}{l}\mathrm{HGH} \\
\text { MTN }\end{array}$ \\
\hline B & $\begin{array}{l}\text { high } \mathrm{SC}, \mathrm{Ca} \text {, and } \mathrm{HCO}_{3} ; \\
\qquad \mathrm{pH}>6.4 ; \mathrm{T}<14^{\circ} \mathrm{C}\end{array}$ & loads higher on PC1 & $\begin{array}{l}\text { lower to upper valley; } \\
\text { elevations } 780-930 ' \\
\quad(238-284 \mathrm{~m})\end{array}$ & $\begin{array}{l}\text { carbonates, } \\
\text { shallow }\end{array}$ & $\begin{array}{l}\text { NEY, } \\
\text { WEB, } \\
\text { CSP }\end{array}$ \\
\hline C & $\begin{array}{l}\text { high SC, } \mathrm{Ca} \text {, and } \mathrm{HCO}_{3} ; \\
\qquad \mathrm{pH}>6.4 ; \mathrm{T}>22^{\circ} \mathrm{C}\end{array}$ & loads higher on PC1 & $\begin{array}{l}\text { ridge base; elevations } \\
\quad=620^{\prime}(189 \mathrm{~m})\end{array}$ & $\begin{array}{l}\text { carbonates, } \\
\text { possible deep flow } \\
\text { component with } \\
\text { travel to surface } \\
\text { through fractures }\end{array}$ & LDY \\
\hline
\end{tabular}


Marcellus/Needmore formations.

The siliceous springs comprising group A are located on the eastern slopes of Cacapon Mountain and likely discharge water from the Tuscarora Formation or the Clinton Group/McKenzie Formation. These springs have chemical variables which load high on PC2, the non-carbonate component.

LDY spring is the only spring whose water issues from a siliceous rock but has a carbonate signature. Although its water (Group C) is very similar chemically to the other springs with carbonate-derived waters (Group B), this spring's water is warm, while the other springs' waters are cold. This suggests that LDY spring has a deep component of flow. A deep flow component further implies that some fraction of the water reaching the spring is old. Age dating using chlorofluorocarbons (CFC-11, CFC-12, and CFC-113) and tritium of waters at Berkeley Springs has supported this assumption (Plummer pers. comm.). Based on these analyses, the springs' waters are thought to be a mixture of young and old with the young fraction being greater than 40 years old and the old fraction being greater than 270 years old, up to 2,700 years old.

LDY spring's relatively large volume of discharge is common of springs at the bases of sandstone ridges in the Valley and Ridge Province (Trapp and Horn 1997). Recharge to thermal springs often takes place on ridge tops and is transported via fractures to minimum depths of 244-1585 m (800-5200 ft). Geothermal heating occurs with deep circulation of ground water, ultimately producing spring waters that may be more mineralized, contain hydrogen sulfide, and have long residence times (Trapp and Horn 1997). Secondary porosity and permeability created by jointing or faulting provides conduits for ground water to reach the surface (Dethier and Harman 1998).

Evidence of former movement along faults is present at Berkeley Springs State Park in the form of slickensides. This feature suggests that secondary porosity created by 
faulting could provide a transportation route for the geothermally heated water to reach the surface before it cools. In Hot Springs National Park, AR the hot-springs water was produced via recharge to an artesian flow system where water moved slowly to and was heated at depth and then quickly delivered to the spring outlet through pathways created by jointing and faulting (Sniegocki 1996).

The Oriskany Formation, from which water at LDY's spring issues, does not exhibit karst features; however, a conduit network in the Helderberg Group could potentially supply water to the underlying system where it would then be delivered to the surface by way of fractures. Overland flow from Warm Spring Ridge could also possibly make its way to the conduit network by way of recharge features such as sinking streams, fissures, or sink holes (Ginsberg and Palmer 2002). These features develop at the contact between insoluble rocks like the Oriskany sandstone and soluble rocks like the limestone unit of the Helderberg Group. A down-dip flow component in the carbonate unit would provide a direct pathway for the ground water to be transported to depth where it would become heated and more mineralized. It could then be carried rapidly to the surface by way of faults or joints. While these flowpaths are possible, they may only be considered speculative as there are no data in this research to confirm their occurrence.

The wells were found to be more widely ranging for chemical parameters relative to springs. Like spring groups B and C, the wells' chemical variables were found to load higher on PC1 than on PC2. In addition to having chemistries indicative of carbonates, this implies that all of the wells in this study are likely completed in carbonate rock sources.

The $\mathrm{Ca} / \mathrm{Mg}$ molar ratio can be useful in determining rock type through which water has flowed (White 1988) and may allude to hydrologic conditions (Langmuir 1971). All waters from carbonate springs and wells had median $\mathrm{Ca} / \mathrm{Mg}$ molar ratios of 3.35 or greater, except for water from STR well. This finding indicates that the source rocks for all of these locations except for STR well, are likely comprised of some limestone. Other studies have 
found $\mathrm{Ca} / \mathrm{Mg}$ molar ratios in limestone above 4 (Jacobson and Langmuir 1969, Langmuir 1971, Shuster and White 1971, White 1988). STR well is probably completed in a carbonate source rock containing a dolomitic unit. 


\subsection{CONCLUSIONS}

Prior to the beginning of this study, little data had been collected that gave a generalized picture of the underlying hydrogeochemistry in the area surrounding Berkeley Springs. The goal of this research was to assemble a dataset that allowed for the characterization of the regional hydrogeologic setting.

The dataset indicates that structural geology, in addition to topography, is a strong control on the hydrology of the region. The potentiometric surface reflects the topography, with high heads on the ridges and low heads in the valley. Recharge on the slopes and ridges was found to flow down-dip toward the major drains in the valley, while ground water in the valley was found to flow along strike.

All wells have carbonate signatures as do all springs except for the siliceous springs MTN and $\mathrm{HGH}$, located on the slopes of Cacapon Mountain. The remaining springs are determined to receive waters that have at least partially flowed through carbonate-rich rocks.

The chemical parameters measured at the springs and wells are consistent with the surface geology where the wells and springs are located at all but one location. Although LDY spring issues from a siliceous unit, its carbonate signature suggests that some portion of flow to the spring occurs through a carbonate or carbonate-cemented source rock. Furthermore, its elevated and consistent temperature is evidence for a deep component of flow to the spring.

Wells were found to have more variable water chemistry and temperature through time than were springs. Instead of collecting water from a single, localized point in the aquifer as the wells do, springs receive water that is chemically averaged as water flows through the rock strata and issues at the spring. This averaging further minimizes potential surface influences that are exhibited in wells. 


\subsection{REFERENCES}

APHA (2005) Standard Methods for the Examination of Water and Wastewater, 21st edn. American Public Health Association, Washington, DC, 1368 pp

Bedinger MS, Pearson FJ, Reed JE, Sniegocki RT, Stone CG (1979) The waters of Hot Springs National Park, Arkansas- their nature and origin. US Geol Surv Pap 1044-C, 33 $\mathrm{pp}$

Berkeley Springs State Park (2004) West Virginia Division of Natural Resources. http://www.berkeleyspringssp.com. Accessed 5 December 2004

Berkeley Springs- The country's first spa (2006) http://www.berkeleysprings.com. Accessed 4 February 2006

Burton WC, Plummer LN, Busenberg E, Lindsey BD, Gburek WJ (2002) Influence of fracture anisotropy on ground water ages and chemistry, Valley and Ridge province, Pennsylvania. Ground Water 40(3):242-257

Cardwell DH, Erwin RB, Woodward HP (1968) Geologic Map of West Virginia, 1:250,000. The West Virginia Geological and Economic Survey

Dethier DP, Harman MT II (1998) Hydrology and geochemistry of the northernmost Appalachian thermal springs, Williamstown, Massachusetts. Northeastern Geology and Environmental Sciences 20(3):200-207

Diecchio RJ, Jones SE, Dennison JM (1984) Oriskany Sandstone: regional stratigraphic relationships and production trends. The West Virginia Geological and Economic Survey Technical Report NP-5900695; MAP-WV-17, 50pp

Donovan JJ, Werner E, Vesper DJ, Corder L (2006) Springs, source water areas, and potential for high-yield aquifers along the Cacapon Mountain anticline, Morgan County, WV. Morgantown, WV, Hydrogeology Research Center of the WV Water Research Institute, $42 \mathrm{pp}$

Environmental Protection Agency (2005) National primary drinking water regulations: Maximum contaminant levels and maximum residual disinfectant levels. 40CFR141. Revised July 1, 2005

Fetter CW (2001) Applied Hydrogeology, 4th Edn. Prentice-Hall, Upper Saddle River New Jersey, $691 \mathrm{pp}$

Grimsley GP, White IC (1916) Jefferson, Morgan, and Berkeley counties. West Virginia Geological and Economic Survey: County Geologic Report-10, 644 pp

Ginsberg M, Palmer AN (2002) Delineation of source-water protection areas in karst aquifers of the Ridge and Valley and Appalachian Plateaus Physiographic Provinces: Rules of thumb for estimating the capture zones of springs and wells. Office of Ground Water and Drinking Water, EPA 816-R-02-015, 41pp 
Gustafsson JP (2004) Visual MINTEQ version 2.30.

http://www.kwr.kth.se/English/OurSoftware/vminteq/. Accessed April 18, 2008. Updated $10 / 24 / 2007$

Heald MT, Thomson A, Wilcox FB (1962) Origin of interstitial porosity in the Oriskany sandstone of Kanawha County, West Virginia. J Sedimentary Petrology 32(2):291-298

Hobba WA, Chemerys JC, Fisher DW, Pearson FJ (1977) Geochemical and hydrologic data for wells and springs in thermal-spring areas of the Appalachians. US Geol Surv WatRes Invest Pap: 77-25, 36 pp

Jacobson RL, Langmuir D (1969) The chemical history of some spring waters in carbonate rocks. Paper presented at the 1969 NWWA Exposition under the title "The hydrochemistry of sinking and resurgent streams in carbonate rocks of central Pennsylvania," 30 September 1969

Kachigan, SK (1986) Statistical Analysis- An introduction to univariate \& multivariate methods. Radius Press, New York, 589 pp

Langmuir, D (1971) The geochemistry of some carbonate ground waters in central Pennsylvania. Geochimica et Cosmochimica Acta 35(10):1023-1045

Lapham WW, Wilde FD, Koterba MT (1997) Guidelines and standard procedures for studies of ground-water quality: selection and installation of wells, and supporting documentation. US Geol Surv Wat-Res Invest Pap: 96-4233, 110 pp

McColloch JS (1986) Springs of West Virginia. West Virginia Geological and Economic Survey: V-6A, pp 265-268

Minke JG (1964) Geology of the Hancock and Stotlers Crossroads quadrangles in West Virginia. MSc, West Virginia University, Morgantown, West Virginia, 41 pp

Minitab Inc. (2000) Minitab® Statistical Software Release 13.3. http://www.minitab.com. Accessed April 182008

National Oceanic and Atmospheric Administration (2005) Record of climatological observations. National Environmental, Satellite, Data, and Information Service/National Climatic Data Center, Asheville, NC

Palmer, AN (2007) Cave Geology. Cave Books, Dayton, OH, 454 pp

Price PH, Ludlum JC (1951) The geology of Cacapon State Park, West Virginia. State Park Series Bulletin No. 2, 33 pp

Rounds SA, Wilde FD (2002) Alkalinity and acid neutralizing capacity, 2nd edn.: Techniques of water-resources investigations of the US Geol Surv, Book 9, Chap A6, 50 pp

Scanlon BR, Thrailkill J (1987) Chemical similarities among physically distinct spring types in a karst terrain. J Hydrol 89:259-279 
Shuster ET, White WB (1971) Seasonal fluctuations in the chemistry of limestone springs: a possible means for characterizing carbonate aquifers. J Hydrol 14:93-128

Sniegocki RT (1996) Waters of hot springs national park, Arkansas- their nature and origin. Environ Geol 27(2):79

Trapp H, Horn, MA (1997) Ground water atlas of the United States, Segment 11-Delaware, Maryland, New Jersey, North Carolina, Pennsylvania, Virginia, and West Virginia. US Geol Surv Hydrologic Investigations Atlas 730-L, 24 pp

West Virginia Geological and Economic Survey (2005) Physiographic provinces of West Virginia. http://www.wvgs.wvnet.edu/www/index.html. Accessed 12 March 2006

White WB (1988) Geomorphology and Hydrology of Karst Terrains. Oxford University Press, New York, 464 pp

Worthington, SRH (1999). A comprehensive strategy for understanding flow in carbonate aquifers. Karst Modeling: Special Publication 5, The Karst Waters Institute, Charles Town, West Virginia, 30-37. 


\section{APPENDICES}


Table A-1: Field eqiupment list.

\begin{tabular}{|c|c|c|c|c|}
\hline PARAMETER & UNITS & EQUIPMENT & $\begin{array}{l}\text { EQUIPMENT } \\
\text { ACCURACY }\end{array}$ & $\begin{array}{l}\text { POTENTIAL } \\
\text { ERROR }\end{array}$ \\
\hline $\mathrm{pH}$ & $\mathrm{pH}$ units & $\begin{array}{l}\text { Hanna HI-9025 } \\
\text { pH/Temperature } \\
\text { Meter }\end{array}$ & $\pm .01 \mathrm{pH}$ & Calibration \\
\hline Temperature & ${ }^{\circ}$ Celsius & $\begin{array}{c}\text { Hanna HI-9025 } \\
\text { pH/Temperature } \\
\text { Meter }\end{array}$ & $\pm 0.5^{\circ} \mathrm{C}$ & Calibration \\
\hline Conductivity & $\mu \mathrm{S} / \mathrm{cm}$ & $\begin{array}{c}\text { Hanna HI-9033 } \\
\text { Conductivity Meter }\end{array}$ & $\pm 1 \%$ Full Scale & Calibration \\
\hline Alkalinity & $\mathrm{mg} / \mathrm{L}$ as $\mathrm{HCO}_{3}^{-}$ & $\begin{array}{l}\text { Digital Titrator } \\
\text { Model } 16900\end{array}$ & $\pm 1 \%$ & Degassing \\
\hline Total Hardness & $\mathrm{mg} / \mathrm{L}$ as $\mathrm{CaCO}_{3}$ & $\begin{array}{l}\text { Hach Colorimeter } \\
8030\end{array}$ & $\begin{array}{c}0.02-0.05 \mathrm{mg} / \mathrm{L} \\
\mathrm{CaCO}_{3}\end{array}$ & Dilution error \\
\hline Silicon & $\mathrm{mg} / \mathrm{L}$ & $\begin{array}{c}\text { Hach Colorimeter } \\
8135\end{array}$ & $\pm 1.0 \mathrm{mg} / \mathrm{L} \mathrm{SiO}_{2}$ & $\begin{array}{c}\text { Incorrect amount of } \\
\text { sample }\end{array}$ \\
\hline Flow & $\mathrm{ft} / \mathrm{s}$ & $\begin{array}{l}\text { Swoffer Current } \\
\text { Meter } 2100\end{array}$ & & $\begin{array}{l}\text { Calibration, poor } \\
\text { site selection, } \\
\text { obstructions in } \\
\text { channel }\end{array}$ \\
\hline Location & NAD-83 utm & $\begin{array}{c}\text { Garmin Etrex Vista } \\
\text { GPS }\end{array}$ & $\begin{array}{l}\text { Varies with clouds } \\
\text { and coverage }\end{array}$ & $\begin{array}{l}\text { Limited satellite } \\
\text { reception }\end{array}$ \\
\hline Static Water Level & $\mathrm{ft} / \mathrm{s}$ & $\begin{array}{c}\text { Graduated Steel } \\
\text { Tape }\end{array}$ & 0.01 & Splash on tape \\
\hline
\end{tabular}


Table A-2: Synoptic well survey data. (Page 1 of 4 )

\begin{tabular}{|c|c|c|c|c|c|c|c|c|c|}
\hline Date & Latitude & Longitude & Northing & Easting & SWL (ft) & $\mathrm{SWL}(\mathrm{m})$ & $\mathrm{pH}$ & $\mathrm{T}\left({ }^{\circ} \mathrm{C}\right)$ & $\mathrm{SC}(\mu \mathrm{S} / \mathrm{cm})$ \\
\hline $5 / 20 / 2004$ & 39.64 & -78.24 & 4390895.79 & 736470.01 & 858 & 262 & NM & NM & NM \\
\hline $5 / 20 / 2004$ & 39.63 & -78.24 & 4390874.11 & 736467.62 & 859 & 262 & 6.99 & 13.8 & 305 \\
\hline $5 / 20 / 2004$ & 39.64 & -78.24 & 4391514.48 & 736481.48 & 788 & 240 & 9.69 & 26.4 & 300 \\
\hline $5 / 20 / 2004$ & 39.64 & -78.24 & 4390973.56 & 736442.65 & 861 & 262 & 6.72 & 22 & NM \\
\hline $5 / 25 / 2004$ & 39.64 & -78.24 & 4390932.33 & 736435.06 & 860 & 262 & 6.86 & NM & 100 \\
\hline $5 / 25 / 2004$ & 39.64 & -78.25 & 4390968.50 & 736169.18 & 831 & 253 & NM & NM & NM \\
\hline $5 / 26 / 2004$ & 39.64 & -78.25 & 4391008.51 & 736174.16 & 774 & 236 & 5.22 & 18.9 & 200 \\
\hline $5 / 26 / 2004$ & 39.63 & -78.25 & 4390630.30 & 736339.75 & 854 & 260 & 6.60 & 14.8 & 298 \\
\hline $5 / 26 / 2004$ & 39.63 & -78.25 & 4390310.57 & 736275.66 & 908 & 277 & 6.85 & 19.6 & 235 \\
\hline $5 / 26 / 2004$ & 39.61 & -78.25 & 4388152.35 & 735772.39 & 644 & 196 & 7.42 & 17.5 & 397 \\
\hline $5 / 26 / 2004$ & 39.61 & -78.25 & 4388427.78 & 735910.52 & 632 & 193 & 7.73 & 16.2 & 500 \\
\hline $5 / 27 / 2004$ & 39.62 & -78.25 & 4388737.41 & 735736.98 & 755 & 230 & 7.50 & 16.7 & 336 \\
\hline $5 / 27 / 2004$ & 39.63 & -78.24 & 4389924.93 & 736575.66 & 620 & 189 & 7.03 & 19.4 & 562 \\
\hline $5 / 27 / 2004$ & 39.63 & -78.23 & 4390382.97 & 737400.79 & 768 & 234 & 6.92 & 22.9 & 515 \\
\hline $5 / 27 / 2004$ & 39.63 & -78.23 & 4390804.14 & 737321.85 & 751 & 229 & 6.72 & 15.1 & 188 \\
\hline $5 / 27 / 2004$ & 39.63 & -78.25 & 4390489.51 & 736304.45 & 861 & 262 & 6.13 & 15.1 & 265 \\
\hline $5 / 27 / 2004$ & 39.61 & -78.26 & 4387911.84 & 735625.27 & 682 & 208 & 6.98 & 15.2 & 350 \\
\hline $6 / 8 / 2004$ & 39.62 & -78.24 & 4388819.12 & 736649.49 & 737 & 225 & 7.48 & 15.1 & 475 \\
\hline $6 / 8 / 2004$ & 39.62 & -78.24 & 4388753.97 & 736812.27 & 830 & 253 & 7.06 & 15.9 & 425 \\
\hline $6 / 8 / 2004$ & 39.55 & -78.28 & 4381229.88 & 733577.51 & 891 & 272 & 7.36 & 26.5 & 303 \\
\hline $6 / 8 / 2004$ & 39.62 & -78.24 & 4389046.35 & 736864.67 & 844 & 257 & 6.10 & 15.4 & NM \\
\hline $6 / 9 / 2004$ & 39.62 & -78.24 & 4389639.34 & 737221.40 & 719 & 219 & 6.99 & 17.8 & NM \\
\hline $6 / 9 / 2004$ & 39.57 & -78.28 & 4383229.41 & 734072.46 & 792 & 241 & 7.13 & 18.3 & NM \\
\hline $6 / 9 / 2004$ & 39.64 & -78.23 & 4391987.06 & 737370.03 & 464 & 142 & 6.10 & 17.1 & NM \\
\hline $6 / 10 / 2004$ & 39.64 & -78.25 & 4390916.36 & 736285.48 & 856 & 261 & 6.79 & 15.6 & NM \\
\hline $6 / 10 / 2004$ & 39.62 & -78.24 & 4389154.74 & 736732.60 & 737 & 225 & 7.12 & 16.0 & NM \\
\hline $6 / 10 / 2004$ & 39.63 & -78.23 & 4390572.86 & 737390.29 & 788 & 240 & 6.30 & 25.9 & NM \\
\hline $6 / 10 / 2004$ & 39.61 & -78.25 & 4388506.16 & 736189.54 & 694 & 212 & 7.12 & 23.5 & NM \\
\hline $6 / 15 / 2004$ & 39.55 & -78.28 & 4381244.29 & 733353.61 & 876 & 267 & 7.25 & 21.3 & NM \\
\hline $6 / 15 / 2004$ & 39.55 & -78.29 & 4381373.80 & 733242.30 & 890 & 271 & 7.01 & 23.0 & NM \\
\hline $6 / 15 / 2004$ & 39.55 & -78.27 & 4381709.71 & 734274.71 & 927 & 282 & 7.00 & 36.4 & NM \\
\hline $6 / 15 / 2004$ & 39.54 & -78.28 & 4380770.40 & 733737.35 & 970 & 296 & NM & NM & NM \\
\hline $6 / 15 / 2004$ & 39.55 & -78.28 & 4381017.02 & 733777.18 & 931 & 284 & 6.95 & 18.2 & NM \\
\hline $6 / 16 / 2004$ & 39.55 & -78.28 & 4381650.25 & 734121.28 & 902 & 275 & 6.75 & 13.9 & NM \\
\hline
\end{tabular}

SWL- elevation of water level above mean sea level; NM- not measured. 
Table A-2: Synoptic well survey data. (Page 2 of 4 )

\begin{tabular}{|c|c|c|c|c|c|c|c|c|c|}
\hline Date & Latitude & Longitude & Northing & Easting & $\mathrm{SWL}(\mathrm{ft})$ & $\mathrm{SWL}(\mathrm{m})$ & $\mathrm{pH}$ & $\mathrm{T}\left({ }^{\circ} \mathrm{C}\right)$ & $\mathrm{SC}(\mu \mathrm{S} / \mathrm{cm})$ \\
\hline $6 / 16 / 2004$ & 39.55 & -78.28 & 4381143.55 & 733620.01 & 918 & 280 & NM & NM & NM \\
\hline $6 / 16 / 2004$ & 39.55 & -78.28 & 4381859.69 & 733395.40 & 854 & 260 & 7.05 & 19.4 & NM \\
\hline $6 / 16 / 2004$ & 39.57 & -78.27 & 4383896.78 & 734235.76 & 772 & 235 & NM & NM & NM \\
\hline $6 / 16 / 2004$ & 39.56 & -78.28 & 4382590.56 & 733722.32 & 802 & 244 & 7.31 & 34.8 & NM \\
\hline $6 / 16 / 2004$ & 39.56 & -78.28 & 4382458.96 & 733620.86 & 841 & 257 & 7.33 & 16.5 & NM \\
\hline $6 / 16 / 2004$ & 39.64 & -78.23 & 4390961.13 & 737462.12 & 758 & 231 & NM & NM & NM \\
\hline $6 / 21 / 2004$ & 39.63 & -78.23 & 4390575.56 & 737613.02 & 753 & 229 & 6.57 & 16.1 & NM \\
\hline $6 / 21 / 2004 a$ & 39.55 & -78.28 & 4381440.95 & 733384.70 & 914 & 279 & 6.32 & 35.1 & NM \\
\hline $6 / 21 / 2004 a$ & 39.55 & -78.28 & 4381312.53 & 733762.86 & 883 & 269 & 7.20 & 17.7 & NM \\
\hline $6 / 21 / 2004 a$ & 39.55 & -78.28 & 4381218.00 & 733676.58 & 888 & 271 & 6.95 & 16.3 & NM \\
\hline $6 / 22 / 2004 a$ & 39.55 & -78.28 & 4381575.49 & 733457.01 & 903 & 275 & 6.88 & 17.8 & NM \\
\hline $6 / 22 / 2004 a$ & 39.51 & -78.27 & 4377239.20 & 734625.72 & 687 & 209 & 7.10 & 17.0 & NM \\
\hline $6 / 22 / 2004 a$ & 39.53 & -78.29 & 4378872.25 & 733002.36 & 803 & 245 & NM & NM & NM \\
\hline $6 / 23 / 2004 a$ & 39.53 & -78.29 & 4378912.45 & 733009.32 & 803 & 245 & NM & NM & NM \\
\hline $6 / 23 / 2004 a$ & 39.53 & -78.29 & 4378758.62 & 732934.22 & 819 & 250 & NM & NM & NM \\
\hline $6 / 23 / 2004 a$ & 39.52 & -78.30 & 4377744.87 & 731899.15 & 1220 & 372 & NM & NM & NM \\
\hline $6 / 24 / 2004 a$ & 39.52 & -78.30 & 4377565.78 & 731883.39 & 1209 & 368 & NM & NM & NM \\
\hline $6 / 24 / 2004 a$ & 39.54 & -78.28 & 4380522.84 & 734099.42 & 882 & 269 & NM & NM & NM \\
\hline $6 / 24 / 2004 a$ & 39.54 & -78.27 & 4380434.83 & 734346.41 & 832 & 254 & NM & NM & NM \\
\hline $7 / 7 / 2004$ & 39.53 & -78.30 & 4378684.97 & 731809.24 & 1100 & 335 & 6.21 & 23.0 & 173 \\
\hline $7 / 7 / 2004$ & 39.53 & -78.29 & 4378610.20 & 732818.45 & 832 & 254 & 6.86 & 22.1 & 448 \\
\hline $7 / 7 / 2004$ & 39.52 & -78.29 & 4378386.33 & 732698.31 & 864 & 263 & NM & NM & NM \\
\hline $7 / 7 / 2004$ & 39.52 & -78.29 & 4378125.51 & 732751.46 & 830 & 253 & NM & NM & NM \\
\hline $7 / 7 / 2004$ & 39.54 & -78.29 & 4380548.04 & 732460.94 & 1138 & 347 & NM & NM & NM \\
\hline $7 / 8 / 2004$ & 39.52 & -78.30 & 4378197.08 & 731901.43 & 1059 & 323 & 6.09 & 13.3 & 211 \\
\hline $7 / 8 / 2004 a$ & 39.54 & -78.30 & 4380300.94 & 732373.37 & 1120 & 341 & NM & NM & NM \\
\hline $7 / 8 / 2004 a$ & 39.54 & -78.30 & 4379883.40 & 732175.81 & 1072 & 327 & NM & NM & NM \\
\hline $7 / 8 / 2004 a$ & 39.55 & -78.30 & 4380827.64 & 732369.51 & 1238 & 377 & 6.15 & 21.0 & 138 \\
\hline $7 / 8 / 2004 a$ & 39.55 & -78.29 & 4381582.09 & 733011.58 & 1107 & 338 & NM & NM & NM \\
\hline $7 / 8 / 2004 a$ & 39.50 & -78.28 & 4375285.54 & 733661.68 & 914 & 279 & 7.50 & 19.2 & 322 \\
\hline $7 / 9 / 2004 a$ & 39.56 & -78.28 & 4382353.21 & 733863.38 & 855 & 261 & 6.95 & 33.2 & 353 \\
\hline $7 / 9 / 2004 a$ & 39.56 & -78.28 & 4382383.77 & 733876.03 & 852 & 260 & NM & NM & NM \\
\hline $7 / 9 / 2004 a$ & 39.56 & -78.28 & 4382332.42 & 733910.16 & 834 & 254 & 7.02 & 22.2 & 425 \\
\hline $7 / 12 / 2004 a$ & 39.56 & -78.28 & 4382625.65 & 733955.90 & 803 & 245 & 6.29 & 20.7 & 319 \\
\hline
\end{tabular}

SWL- elevation of water level above mean sea level; NM- not measured; "a"- approximate date. 
Table A-2: Synoptic well survey data. (Page 3 of 4 )

\begin{tabular}{|c|c|c|c|c|c|c|c|c|c|}
\hline Date & Latitude & Longitude & Northing & Easting & SWL $(\mathrm{ft})$ & $\mathrm{SWL}(\mathrm{m})$ & $\mathrm{pH}$ & $\mathrm{T}\left({ }^{\circ} \mathrm{C}\right)$ & $\mathrm{SC}(\mu \mathrm{S} / \mathrm{cm})$ \\
\hline $7 / 12 / 2004 a$ & 39.54 & -78.27 & 4379828.54 & 734686.34 & 922 & 281 & 6.38 & 18.4 & 224 \\
\hline $7 / 12 / 2004 a$ & 39.53 & -78.27 & 4379574.36 & 734482.86 & 899 & 274 & NM & NM & NM \\
\hline $7 / 12 / 2004 a$ & 39.54 & -78.28 & 4379796.71 & 734172.89 & 785 & 239 & NM & NM & NM \\
\hline $7 / 13 / 2004 a$ & 39.49 & -78.28 & 4374915.29 & 734063.20 & 818 & 249 & 7.42 & 22.2 & 324 \\
\hline $7 / 13 / 2004 a$ & 39.50 & -78.29 & 4375410.11 & 732989.11 & 819 & 250 & NM & NM & NM \\
\hline $7 / 13 / 2004 a$ & 39.53 & -78.30 & 4378640.30 & 731984.23 & 1042 & 318 & NM & NM & NM \\
\hline $7 / 13 / 2004 a$ & 39.55 & -78.28 & 4381176.59 & 733309.38 & 864 & 264 & 7.08 & 19.1 & 342 \\
\hline $7 / 13 / 2004 a$ & 39.54 & -78.29 & 4380022.55 & 732847.92 & 915 & 279 & NM & NM & NM \\
\hline $7 / 14 / 2004 a$ & 39.54 & -78.29 & 4380121.98 & 733193.44 & 859 & 262 & NM & NM & NM \\
\hline $7 / 14 / 2004 a$ & 39.56 & -78.28 & 4382744.23 & 733492.46 & 940 & 287 & 6.45 & 14.6 & 284 \\
\hline $7 / 14 / 2004 a$ & 39.57 & -78.28 & 4383056.96 & 733876.39 & 769 & 234 & 7.24 & 18.4 & 266 \\
\hline $7 / 14 / 2004 a$ & 39.57 & -78.28 & 4383090.86 & 733895.45 & 801 & 244 & 7.14 & 18.9 & 245 \\
\hline $7 / 14 / 2004 a$ & 39.57 & -78.28 & 4383122.26 & 733802.77 & 848 & 258 & 6.96 & 26.6 & 404 \\
\hline $7 / 15 / 2004 a$ & 39.54 & -78.29 & 4379825.02 & 733005.42 & 848 & 259 & 7.10 & 19.3 & 435 \\
\hline $7 / 15 / 2004 a$ & 39.56 & -78.27 & 4382850.65 & 734290.31 & 724 & 221 & NM & NM & NM \\
\hline $7 / 15 / 2004 a$ & 39.57 & -78.27 & 4383877.50 & 734281.84 & 779 & 237 & 6.43 & 20.7 & 423 \\
\hline $7 / 15 / 2004 a$ & 39.56 & -78.28 & 4382713.48 & 733764.66 & 798 & 243 & 7.04 & 19.7 & 554 \\
\hline $7 / 16 / 2004 a$ & 39.52 & -78.27 & 4377838.46 & 734582.49 & 685 & 209 & 6.83 & 16.9 & 310 \\
\hline $7 / 16 / 2004 a$ & 39.51 & -78.27 & 4377172.14 & 734762.60 & 710 & 217 & 7.17 & 21.1 & 282 \\
\hline $7 / 16 / 2004 a$ & 39.63 & -78.23 & 4390740.23 & 737511.07 & 768 & 234 & NM & NM & NM \\
\hline $7 / 16 / 2004 a$ & 39.62 & -78.24 & 4389172.99 & 736776.11 & 757 & 231 & NM & NM & NM \\
\hline $7 / 19 / 2004 a$ & 39.62 & -78.24 & 4389452.74 & 736732.12 & 572 & 174 & NM & NM & NM \\
\hline $7 / 19 / 2004 a$ & 39.60 & -78.25 & 4387510.38 & 736301.02 & 762 & 232 & 6.50 & 16.5 & 945 \\
\hline $7 / 19 / 2004 a$ & 39.58 & -78.26 & 4385250.12 & 735396.69 & 855 & 261 & 6.52 & 18.5 & 872 \\
\hline $7 / 19 / 2004 a$ & 39.62 & -78.25 & 4388773.85 & 736167.31 & 750 & 229 & NM & NM & NM \\
\hline $7 / 19 / 2004 a$ & 39.52 & -78.31 & 4378460.07 & 731629.76 & 1085 & 331 & NM & NM & NM \\
\hline $7 / 20 / 2004 a$ & 39.62 & -78.24 & 4388940.18 & 736684.45 & 790 & 241 & NM & NM & NM \\
\hline $7 / 20 / 2004 a$ & 39.54 & -78.27 & 4380614.44 & 734967.03 & 924 & 282 & NM & NM & NM \\
\hline $7 / 20 / 2004 a$ & 39.54 & -78.27 & 4380309.10 & 734961.52 & 932 & 284 & 7.44 & 37.8 & 370 \\
\hline $7 / 21 / 2004 a$ & 39.57 & -78.26 & 4383706.87 & 735582.55 & 801 & 244 & NM & NM & NM \\
\hline $7 / 21 / 2004 a$ & 39.57 & -78.26 & 4383275.82 & 735193.35 & 837 & 255 & NM & NM & NM \\
\hline $7 / 21 / 2004 a$ & 39.55 & -78.27 & 4381365.74 & 734466.14 & 903 & 275 & NM & NM & NM \\
\hline $7 / 21 / 2004 a$ & 39.57 & -78.25 & 4383724.51 & 736171.16 & 852 & 260 & 7.10 & 23.7 & NM \\
\hline $7 / 22 / 2004 a$ & 39.56 & -78.26 & 4382556.20 & 735235.58 & 816 & 249 & 7.16 & 20.2 & 342 \\
\hline
\end{tabular}

SWL- elevation of water level above mean sea level; NM- not measured; "a"- approximate date. 
Table A-2: Synoptic well survey data. (Page 4 of 4)

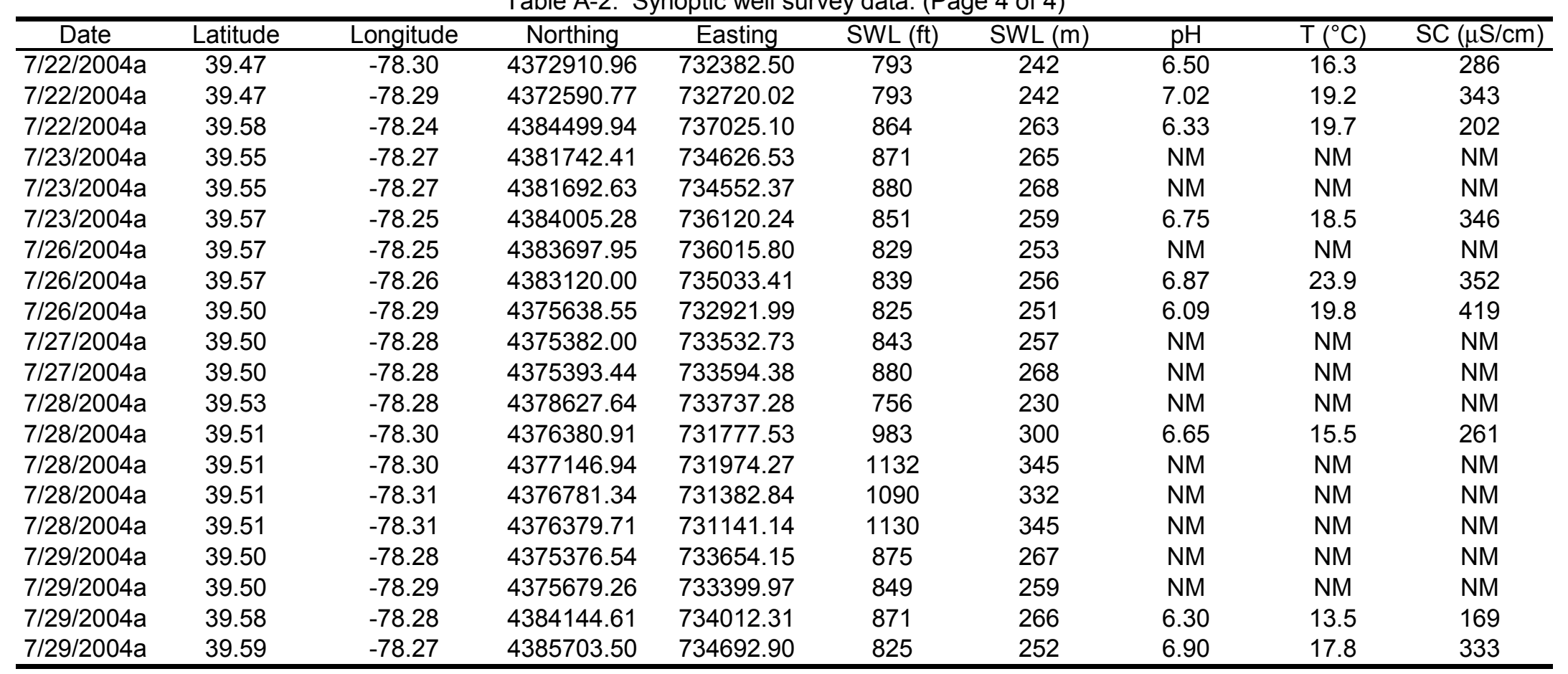

SWL- elevation of water level above mean sea level; NM- not measured; "a"- approximate date. 
Table A-3: Temporal study field measurements. (Page 1 of 2)

\begin{tabular}{|c|c|c|c|c|c|c|c|c|c|}
\hline Sample ID & Date & $\begin{array}{c}\text { Stage } \\
(\mathrm{ft})\end{array}$ & $\begin{array}{c}\text { Stage } \\
(\mathrm{m})\end{array}$ & $\begin{array}{c}\text { Flow } \\
\left(\mathrm{m}^{3} / \mathrm{min}\right)\end{array}$ & $\begin{array}{c}\text { Flow } \\
\text { (gal/min) }\end{array}$ & $\mathrm{pH}$ & $\begin{array}{c}\mathrm{T} \\
\left({ }^{\circ} \mathrm{C}\right)\end{array}$ & $\begin{array}{c}\mathrm{SC} \\
(\mu \mathrm{S} / \mathrm{cm})\end{array}$ & $\begin{array}{c}\text { Alkalinity } \\
\left(\mathrm{mg} / \mathrm{L} \mathrm{HCO}_{3}^{-}\right)\end{array}$ \\
\hline LDY-SP01 & 17-Sep-04 & 620 & 189 & $\overline{--}$ & $\overline{--}$ & 6.82 & 22.5 & 300 & 162 \\
\hline LDY-SP02 & 25-Oct-04 & 620 & 189 & -- & -- & 6.88 & 22.0 & 363 & 185 \\
\hline LDY-SP03 & 29-Nov-04 & 620 & 189 & -- & -- & 6.89 & 22.0 & 271 & 140 \\
\hline LDY-SP04 & 30-Dec-04 & 620 & 189 & -- & -- & 6.84 & 22.0 & 279 & 129 \\
\hline LDY-SP05 & 4-Feb-05 & 620 & 189 & -- & -- & 6.51 & 22.0 & 283 & 148 \\
\hline LDY-SP06 & 14-Mar-05 & 620 & 189 & -- & -- & 6.49 & 22.3 & 276 & 157 \\
\hline LDY-SP07 & 14-Apr-05 & 620 & 189 & -- & -- & 6.46 & 22.3 & 279 & 140 \\
\hline STR-MW02 & 25-Oct-04 & NM & NM & -- & -- & 7.14 & 14.0 & 902 & 450 \\
\hline STR-MW03 & 29-Nov-04 & NM & NM & -- & -- & 7.31 & 11.7 & 779 & 421 \\
\hline STR-MW04 & 30-Dec-04 & NM & NM & -- & -- & 7.30 & 11.3 & 812 & 437 \\
\hline STR-MW06 & 14-Mar-05 & 768 & 234 & -- & -- & 6.86 & 14.4 & 894 & 479 \\
\hline STR-MW07 & 14-Apr-05 & 781 & 238 & -- & -- & 6.86 & 14.4 & 835 & 457 \\
\hline MTN-SP01 & 17-Sep-04 & 980 & 299 & 0.51 & 12 & 5.02 & 13.3 & 51 & 36.6 \\
\hline MTN-SP02 & 25-Oct-04 & 980 & 299 & 0.48 & 12 & 5.11 & 12.5 & 55 & 0.000 \\
\hline MTN-SP03 & 29-Nov-04 & 980 & 299 & 0.38 & 9.2 & 5.08 & 12.4 & 55 & 0.732 \\
\hline MTN-SP04 & 30-Dec-04 & 980 & 299 & NM & NM & 4.99 & 11.8 & 56 & 4.64 \\
\hline MTN-SP05 & 4-Feb-05 & 980 & 299 & 0.30 & 7.3 & 4.45 & 11.5 & 46 & 0.122 \\
\hline MTN-SP06 & 14-Mar-05 & 980 & 299 & 0.33 & 8.1 & 4.56 & 11.1 & 69 & 0.146 \\
\hline MTN-SP07 & 14-Apr-05 & 980 & 299 & 0.75 & 18 & 4.37 & 10.9 & 48 & 3.00 \\
\hline NEY-SP01 & 17-Sep-04 & 780 & 238 & -- & $\overline{--}$ & 7.16 & 12.3 & 365 & 187 \\
\hline NEY-SP02 & 25-Oct-04 & 780 & 238 & -- & -- & 7.19 & 12.4 & 343 & 179 \\
\hline NEY-SP03 & 29-Nov-04 & 780 & 238 & -- & -- & 6.65 & 12.0 & 154 & 79 \\
\hline NEY-SP04 & 30-Dec-04 & 780 & 238 & -- & -- & 6.99 & 11.0 & 211 & 120 \\
\hline NEY-SP05 & 5-Feb-05 & 780 & 238 & -- & -- & 6.67 & 10.7 & 240 & 209 \\
\hline NEY-SP06 & 14-Mar-05 & 780 & 238 & -- & -- & 6.64 & 10.2 & 232 & 125 \\
\hline NEY-SP07 & 14-Apr-05 & 780 & 238 & -- & -- & 6.49 & 10.8 & 221 & 110 \\
\hline WEB-SP01 & 17-Sep-04 & 819 & 250 & 0.13 & 3.2 & 7.15 & 13.6 & 317 & 222 \\
\hline WEB-SP02 & 25-Oct-04 & 819 & 250 & 0.16 & 4.0 & 7.33 & 12.5 & 452 & 220 \\
\hline WEB-SP03 & 29-Nov-04 & 819 & 250 & 0.20 & 4.9 & 7.24 & 12.5 & 338 & 242 \\
\hline WEB-SP04 & 30-Dec-04 & 819 & 250 & 0.20 & 4.8 & 7.26 & 10.6 & 363 & 232 \\
\hline WEB-SP05 & 5-Feb-05 & 819 & 250 & 0.24 & 5.9 & 6.99 & 12.2 & 354 & 270 \\
\hline WEB-SP06 & 14-Mar-05 & 819 & 250 & 0.21 & 5.2 & 6.96 & 12.4 & 347 & 242 \\
\hline WEB-SP07 & 14-Apr-05 & 819 & 250 & 0.20 & 4.8 & 6.96 & 12.4 & 353 & 251 \\
\hline
\end{tabular}

NM- not measured; -- Indicates not applicable. 
Table A-3: Temporal study field measurements. (Page 2 of 2)

\begin{tabular}{|c|c|c|c|c|c|c|c|c|c|}
\hline Sample ID & Date & $\begin{array}{c}\text { Stage } \\
(\mathrm{ft})\end{array}$ & $\begin{array}{l}\text { Stage } \\
(\mathrm{m})\end{array}$ & $\begin{array}{c}\text { Flow } \\
\left(\mathrm{m}^{3} / \mathrm{min}\right)\end{array}$ & $\begin{array}{c}\text { Flow } \\
\text { (gal/min) }\end{array}$ & $\mathrm{pH}$ & $\begin{array}{c}\mathrm{T} \\
\left({ }^{\circ} \mathrm{C}\right)\end{array}$ & $\begin{array}{c}\mathrm{SC} \\
(\mu \mathrm{S} / \mathrm{cm})\end{array}$ & $\begin{array}{c}\text { Alkalinity } \\
\left(\mathrm{mg}^{2} \mathrm{LCO}_{3}^{-}\right)\end{array}$ \\
\hline MYR-MW02 & $25-O c t-04$ & 812 & 247 & -- & -- & 6.08 & 15.0 & 273 & 80 \\
\hline MYR-MW03 & 29-Nov-04 & 816 & 249 & -- & -- & 5.87 & 11.5 & 282 & 86 \\
\hline MYR-MW04 & 30-Dec-04 & 811 & 247 & -- & -- & 6.02 & 7.9 & 237 & 44 \\
\hline MYR-MW05 & 5-Feb-05 & 811 & 247 & -- & -- & 6.19 & 6.9 & 286 & 159 \\
\hline MYR-MW06 & 14-Mar-05 & 810 & 247 & -- & -- & 5.83 & 5.5 & 253 & 85 \\
\hline MYR-MW07 & 14-Apr-05 & 813 & 248 & -- & -- & 5.86 & 12.3 & 252 & 73 \\
\hline BZK-MW02 & $25-O c t-04$ & 868 & 265 & -- & -- & 7.31 & 13.8 & 557 & 266 \\
\hline BZK-MW03 & 29-Nov-04 & 869 & 265 & -- & -- & 7.33 & 9.4 & 539 & 256 \\
\hline BZK-MW04 & 30-Dec-04 & 873 & 266 & -- & -- & 7.16 & 6.3 & 484 & 245 \\
\hline BZK-MW05 & 5-Feb-05 & 874 & 267 & -- & -- & 7.13 & 7.2 & 477 & 312 \\
\hline BZK-MW06 & 14-Mar-05 & 874 & 266 & -- & -- & 7.03 & 4.1 & 484 & 259 \\
\hline BZK-MW07 & 14-Apr-05 & 881 & 269 & -- & -- & 7.06 & 14.4 & 494 & 238 \\
\hline YST-SP01 & 17-Sep-04 & NM & NM & 3.1 & 75 & 5.00 & 12.1 & 46 & 12 \\
\hline YST-SP02 & 25-Oct-04 & NM & NM & 2.0 & 50 & 5.08 & 12.1 & 52 & 0.7 \\
\hline HGH-SP03 & 29-Nov-04 & NM & NM & 4.1 & 100 & 4.58 & 12.3 & 42 & 0.0 \\
\hline HGH-SP04 & 30-Dec-04 & NM & NM & 3.1 & 75 & 4.74 & 12.0 & 41 & 2.0 \\
\hline HGH-SP05 & 5-Feb-05 & NM & NM & 3.1 & 75 & 4.15 & 11.9 & 32 & 0.0 \\
\hline HGH-SP07 & 13-Apr-05 & NM & NM & 6.1 & 150 & 3.97 & 11.7 & 43 & 0.0 \\
\hline YST-MW01 & 17-Sep-04 & 1062 & 324 & -- & -- & 6.57 & 16.3 & 206 & 117 \\
\hline YST-MW02 & 25-Oct-04 & 1063 & 324 & -- & -- & 6.76 & 17.0 & 249 & 119 \\
\hline YST-MW03 & 29-Nov-04 & 1061 & 323 & -- & -- & 6.69 & 16.9 & 200 & 123 \\
\hline YST-MW04 & 30-Dec-04 & 1062 & 324 & -- & -- & 6.56 & 13.1 & 188 & 88 \\
\hline YST-MW05 & 5-Feb-05 & 1061 & 324 & -- & -- & 6.25 & 12.2 & 188 & 160 \\
\hline YST-MW07 & 13-Apr-05 & 1055 & 322 & -- & -- & 6.40 & 11.8 & 184 & 102 \\
\hline CSP-SP01 & 17-Sep-04 & 929 & 283 & -- & -- & 6.85 & 13.6 & 297 & 226 \\
\hline CSP-SP02 & 25-Oct-04 & 930 & 284 & -- & -- & 7.17 & 12.1 & 358 & 201 \\
\hline CSP-SP03 & 29-Nov-04 & 929 & 283 & -- & -- & 7.12 & 11.9 & 278 & 191 \\
\hline CSP-SP04 & 30-Dec-04 & 929 & 283 & -- & -- & 7.11 & 11.8 & 324 & 190 \\
\hline CSP-SP05 & 5-Feb-05 & 929 & 283 & -- & -- & 6.87 & 11.7 & 294 & 270 \\
\hline CSP-SP06 & 14-Mar-05 & 929 & 283 & -- & -- & 6.61 & 11.7 & 318 & 182 \\
\hline CSP-SP07 & 14-Apr-05 & 929 & 283 & -- & -- & 6.79 & 11.8 & 312 & 212 \\
\hline
\end{tabular}

NM- not measured; -- Indicates not applicable. 
Table A-4: Daily temperature measurements at Berkeley Springs $3 \mathrm{~S}$ weather station.

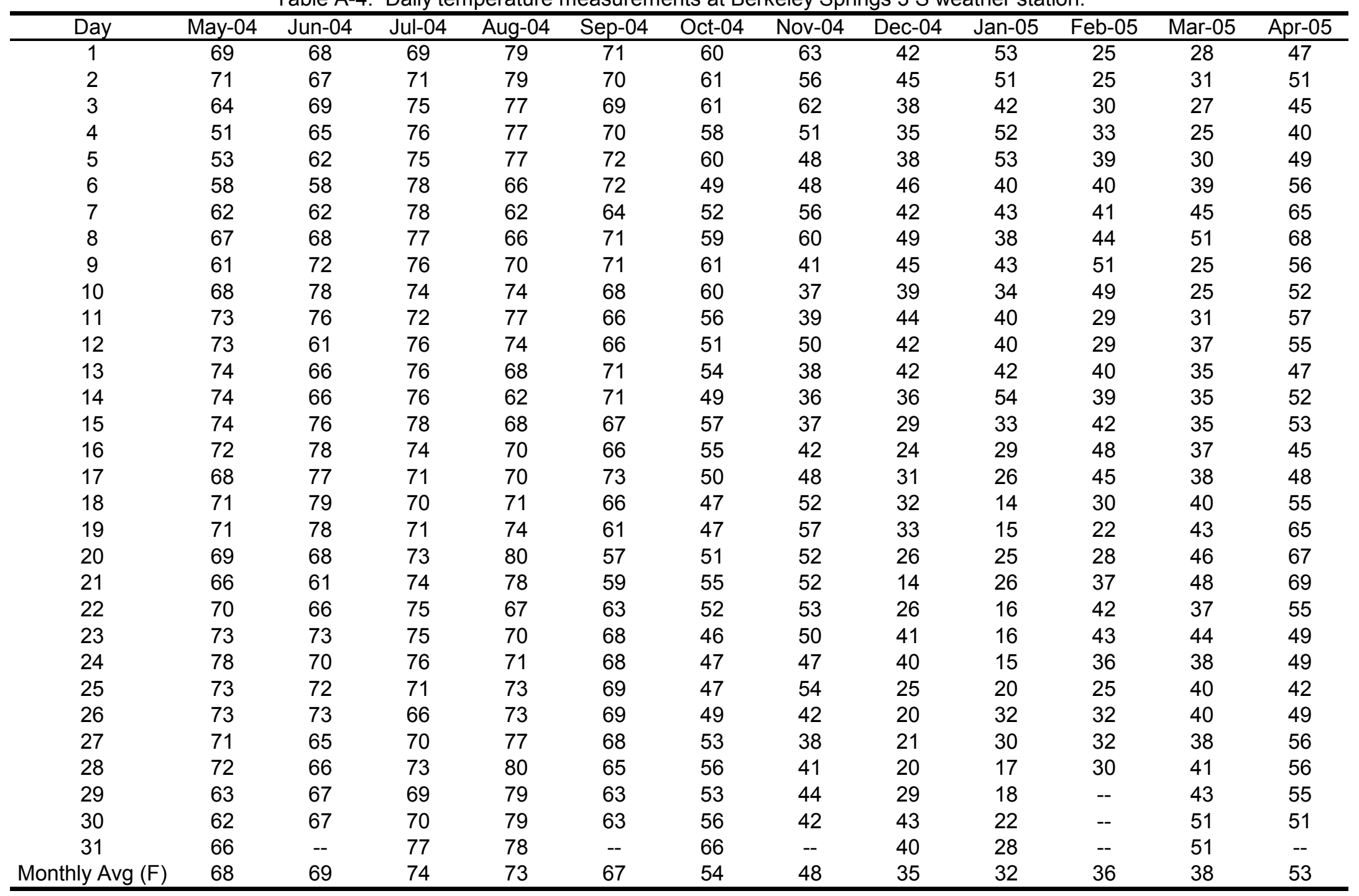


Table A-5: Daily rainfall measurements at Berkeley Springs $3 \mathrm{~S}$ weather station.

\begin{tabular}{|c|c|c|c|c|c|c|c|c|c|c|c|c|}
\hline Day & May-04 & Jun-04 & Jul-04 & Aug-04 & Sep-04 & Oct-04 & Nov-04 & Dec-04 & Jan-05 & Feb-05 & Mar-05 & Apr-05 \\
\hline 1 & -- & 0.26 & -- & 2.37 & -- & -- & -- & 0.55 & -- & -- & 0.48 & -- \\
\hline 2 & 0.04 & 0.02 & -- & 0.01 & -- & -- & -- & 0.03 & -- & -- & -- & 0.35 \\
\hline 3 & 0.71 & 0.12 & -- & -- & -- & 0.01 & 0.03 & -- & -- & -- & -- & 0.77 \\
\hline 5 & -- & 1.03 & 0.14 & 0.29 & & -- & 0.88 & -- & 0.38 & -- & -- & -- \\
\hline 6 & -- & 0.53 & -- & -- & 0.04 & -- & -- & 0.02 & 0.7 & -- & -- & -- \\
\hline 7 & -- & -- & 0.02 & -- & 0.03 & -- & -- & 0.12 & 0.04 & -- & -- & -- \\
\hline 8 & 0.17 & -- & 0.03 & -- & 0.49 & -- & -- & 0.2 & 0.37 & -- & 0.09 & 0.46 \\
\hline 9 & -- & -- & -- & -- & 5.49 & -- & -- & & 0.11 & -- & 0.13 & -- \\
\hline 10 & -- & -- & -- & 0.02 & 0.03 & -- & -- & 0.69 & & 0.25 & 0.01 & -- \\
\hline 11 & -- & 0.26 & -- & -- & -- & -- & -- & 0.37 & -- & -- & -- & -- \\
\hline 12 & -- & 1.24 & 0.35 & 0.84 & -- & -- & 0.62 & -- & 0.24 & -- & 0.01 & -- \\
\hline 13 & -- & 0.1 & 1.26 & -- & -- & -- & 0.48 & 0.02 & 0.03 & -- & -- & -- \\
\hline 14 & -- & 0.07 & 0.09 & -- & -- & 0.23 & -- & -- & 0.7 & 0.14 & -- & -- \\
\hline 15 & 0.49 & 0.01 & -- & -- & 0.45 & 0.09 & -- & -- & -- & 0.32 & -- & -- \\
\hline 16 & 0.7 & 0.1 & -- & 0.02 & 0.01 & 0.06 & -- & -- & -- & & -- & -- \\
\hline 18 & -- & 0.14 & 0.19 & 0.04 & 3.72 & -- & 0.04 & -- & -- & -- & -- & -- \\
\hline 19 & 1.13 & -- & 0.02 & 0.05 & -- & 0.21 & & -- & -- & -- & -- & -- \\
\hline 20 & 0.2 & -- & 0.01 & 0.6 & -- & 0.11 & 0.31 & -- & 0.01 & -- & -- & -- \\
\hline 21 & 0.02 & -- & -- & 0.14 & -- & 0.66 & 0.02 & -- & & 0.19 & 0.02 & -- \\
\hline 22 & 0.58 & -- & -- & -- & -- & 0.07 & -- & -- & 0.01 & -- & -- & 0.06 \\
\hline 23 & -- & 0.17 & 0.15 & -- & -- & 0.02 & 0.03 & 0.01 & 0.5 & -- & 0.87 & 0.57 \\
\hline 24 & -- & 0.01 & 0.24 & -- & -- & 0.08 & 0.15 & 0.34 & -- & 0.03 & 0.71 & 0.1 \\
\hline 25 & 0.01 & -- & -- & -- & -- & 0.16 & 0.93 & -- & -- & 0.66 & 0.02 & 0.02 \\
\hline 26 & 0.2 & 0.08 & 0.05 & -- & -- & -- & 0.04 & -- & 0.01 & -- & 0.09 & -- \\
\hline 27 & 0.24 & -- & 0.12 & -- & -- & -- & & -- & -- & -- & 0.02 & -- \\
\hline 28 & 0.03 & -- & 0.75 & -- & 0.54 & -- & 0.72 & -- & -- & -- & 0.56 & -- \\
\hline 29 & 0.2 & 0.02 & -- & 0.02 & 2.73 & -- & -- & -- & -- & -- & 1.65 & -- \\
\hline 30 & -- & -- & -- & -- & 0.02 & 0.08 & -- & -- & 0.05 & -- & -- & 0.24 \\
\hline 31 & -- & -- & 0.03 & -- & -- & -- & -- & -- & 0.01 & -- & 0.01 & -- \\
\hline Monthly Total (mm) & 120 & 106 & 87.6 & 112 & 346 & 52.1 & 108 & 59.7 & 81.8 & 42.2 & 119 & 65.3 \\
\hline Monthly Total (in) & 4.72 & 4.17 & 3.45 & 4.4 & 13.61 & 2.05 & 4.25 & 2.35 & 3.22 & 1.66 & 4.67 & 2.57 \\
\hline
\end{tabular}


Table A-6: Laboratory data. (Page 1 of 2)

\begin{tabular}{|c|c|c|c|c|c|c|c|c|c|c|c|c|}
\hline Sample ID & Date & $\begin{array}{c}\mathrm{Ca} \\
(\mathrm{mg} / \mathrm{L})\end{array}$ & $\begin{array}{c}\mathrm{Mg} \\
(\mathrm{mg} / \mathrm{L})\end{array}$ & $\begin{array}{c}\mathrm{Na} \\
(\mathrm{mg} / \mathrm{L})\end{array}$ & $\begin{array}{c}\mathrm{K} \\
(\mathrm{mg} / \mathrm{L})\end{array}$ & $\begin{array}{c}\mathrm{Fe} \\
(\mathrm{mg} / \mathrm{L})\end{array}$ & $\begin{array}{c}\mathrm{Mn} \\
(\mathrm{mg} / \mathrm{L})\end{array}$ & $\begin{array}{c}\mathrm{Si} \\
(\mathrm{mg} / \mathrm{L})\end{array}$ & $\begin{array}{c}\mathrm{S} \\
(\mathrm{mg} / \mathrm{L})\end{array}$ & $\begin{array}{c}\mathrm{SO}_{4} \\
(\mathrm{mg} / \mathrm{L})\end{array}$ & $\begin{array}{c}\mathrm{Cl} \\
(\mathrm{mg} / \mathrm{L})\end{array}$ & $\begin{array}{c}\mathrm{NO}_{3} \\
(\mathrm{mg} / \mathrm{L})\end{array}$ \\
\hline LDY-SPO1 & 17-Sep-04 & 53.4 & 5.22 & 5.25 & 1.12 & $<0.1$ & $<0.1$ & 4.76 & -- & 12.5 & 2.5 & 0.24 \\
\hline LDY-SPO2 & 25-Oct-04 & 47.2 & 4.83 & 4.15 & 0.85 & $<0.1$ & $<0.1$ & 4.52 & 4.57 & -- & -- & -- \\
\hline LDY-SPO3 & 29-Nov-04 & 54.9 & 5.63 & 4.76 & 1.05 & $<0.1$ & $<0.1$ & 5.08 & 5.13 & -- & -- & -- \\
\hline LDY-SPO4 & 30-Dec-04 & 38.7 & 4.34 & 3.42 & 0.78 & $<0.1$ & $<0.1$ & 3.82 & 3.63 & -- & -- & -- \\
\hline LDY-SPO5 & 4-Feb-05 & 48.7 & 4.21 & 3.92 & 0.80 & -- & -- & 4.51 & -- & 14.3 & 3.30 & 0.04 \\
\hline LDY-SPO6 & 14-Mar-05 & 48.1 & 4.78 & -- & -- & -- & -- & 4.46 & 5.26 & -- & 3.31 & -- \\
\hline LDY-SPO7 & 14-Apr-05 & 48.1 & 4.67 & -- & -- & -- & -- & 4.29 & 5.44 & -- & 2.92 & -- \\
\hline STR-MWO2 & $25-O c t-04$ & 118 & 37.4 & 16.1 & 0.89 & 0.13 & $<0.1$ & 3.59 & 16.7 & -- & -- & $\begin{array}{l}- \\
-\end{array}$ \\
\hline STR-MWO3 & 29-Nov-04 & 110 & 30.5 & 15.9 & 0.90 & 0.16 & $<0.1$ & 3.52 & 9.85 & -- & -- & -- \\
\hline STR-MWO4 & 30-Dec-04 & 111 & 36.3 & 19.9 & 0.92 & 0.13 & $<0.1$ & 3.72 & 13.3 & -- & -- & -- \\
\hline STR-DPO4 & 30-Dec-04 & 115 & 37.2 & 17.7 & 0.95 & 0.12 & $<0.1$ & 3.71 & 13.6 & -- & -- & -- \\
\hline STR-MWO6 & 14-Mar-05 & 127 & 37.4 & -- & -- & -- & -- & 3.51 & 16.28 & -- & 42.1 & -- \\
\hline STR-MWO7 & 14-Apr-05 & 112 & 38.8 & -- & -- & -- & -- & 3.37 & 13.5 & -- & 36.0 & -- \\
\hline MTN-SPO1 & 17-Sep-04 & 3.31 & 2.13 & 0.79 & 0.89 & $<0.1$ & $<0.1$ & 2.84 & -- & 8.76 & 1.41 & 0.58 \\
\hline MTN-SPO2 & 25-Oct-04 & 2.90 & 1.98 & 2.08 & 0.73 & $<0.1$ & $<0.1$ & 2.38 & 2.47 & -- & -- & -- \\
\hline MTN-SPO3 & 29-Nov-04 & 3.45 & 2.58 & 0.62 & 0.86 & $<0.1$ & $<0.1$ & 2.68 & 3.39 & -- & -- & -- \\
\hline MTN-SPO4 & 30-Dec-04 & 3.71 & 2.72 & 0.75 & 1.01 & 0.16 & $<0.1$ & 3.13 & 3.28 & -- & -- & -- \\
\hline MTN-SPO5 & 4-Feb-05 & 2.96 & 2.16 & 0.68 & 0.78 & -- & -- & 3.05 & -- & 9.30 & 1.49 & 0.33 \\
\hline MTN-SPO6 & 14-Mar-05 & 3.38 & 2.26 & -- & -- & -- & -- & 2.50 & 4.07 & -- & 1.87 & -- \\
\hline MTN-SPO7 & 14-Apr-05 & 3.31 & 2.22 & -- & -- & -- & -- & 2.55 & 4.02 & -- & 1.96 & -- \\
\hline NEY-SPO1 & 17-Sep-04 & 56.1 & 9.37 & 2.49 & 1.06 & $<0.1$ & $<0.1$ & 3.46 & -- & 6.98 & 5.02 & 0.12 \\
\hline NEY-SPO2 & 25-Oct-04 & 40.6 & 7.39 & 1.82 & 0.79 & $<0.1$ & $<0.1$ & 2.68 & 1.39 & -- & -- & -- \\
\hline NEY-SPO3 & 29-Nov-04 & 21.2 & 4.50 & 2.92 & 1.05 & $<0.1$ & $<0.1$ & 2.83 & 2.82 & -- & -- & -- \\
\hline NEY-SPO4 & 30-Dec-04 & 33.3 & 6.30 & 1.66 & 0.88 & $<0.1$ & $<0.1$ & 2.99 & 2.19 & -- & -- & -- \\
\hline NEY-SPO5 & 4-Feb-05 & 44.9 & 6.97 & 1.97 & 0.87 & -- & -- & 3.57 & -- & 5.84 & 4.24 & 0.25 \\
\hline NEY-SPO6 & 14-Mar-05 & 38.5 & 6.51 & -- & -- & -- & -- & 2.89 & 2.47 & -- & 5.08 & -- \\
\hline NEY-SPO7 & 14-Apr-05 & 35.1 & 6.19 & -- & -- & -- & -- & 2.97 & 2.88 & -- & 5.14 & -- \\
\hline WEB-SPO1 & 17-Sep-04 & 62.5 & 9.41 & 2.58 & 0.62 & $<0.1$ & $<0.1$ & 3.40 & -- & 6.47 & 6.09 & 0.22 \\
\hline WEB-SPO2 & 25-Oct-04 & 26.1 & 12.91 & 3.49 & 0.68 & $<0.1$ & $<0.1$ & 4.38 & 1.56 & -- & -- & -- \\
\hline WEB-SPO3 & 29-Nov-04 & 60.3 & 10.14 & 2.23 & 0.55 & $<0.1$ & $<0.1$ & 3.53 & 0.68 & -- & -- & -- \\
\hline WEB-SPO4 & 30-Dec-04 & 58.7 & 10.16 & 2.51 & 0.59 & $<0.1$ & $<0.1$ & 3.55 & 1.19 & -- & -- & -- \\
\hline WEB-SPO5 & 4-Feb-05 & 71.9 & 10.74 & 2.35 & 0.60 & -- & -- & 4.42 & -- & 3.54 & 6.34 & 0.20 \\
\hline WEB-SPO6 & 14-Mar-05 & 64.2 & 9.49 & -- & -- & -- & -- & 3.46 & 1.26 & -- & 6.32 & -- \\
\hline WEB-SPO7 & 14-Apr-05 & 63.1 & 8.54 & -- & -- & -- & -- & 3.48 & 1.48 & -- & 6.14 & -- \\
\hline
\end{tabular}

$<$ Indicates below detection limit, followed by the detection limit. 
Table A-6: Laboratory data. (Page 2 of 2)

\begin{tabular}{|c|c|c|c|c|c|c|c|c|c|c|c|c|}
\hline Sample ID & Date & $\begin{array}{c}\mathrm{Ca} \\
(\mathrm{mg} / \mathrm{L})\end{array}$ & $\begin{array}{c}\mathrm{Mg} \\
(\mathrm{mg} / \mathrm{L})\end{array}$ & $\begin{array}{c}\mathrm{Na} \\
(\mathrm{mg} / \mathrm{L})\end{array}$ & $\begin{array}{c}\mathrm{K} \\
(\mathrm{mg} / \mathrm{L})\end{array}$ & $\begin{array}{c}\mathrm{Fe} \\
(\mathrm{mg} / \mathrm{L})\end{array}$ & $\begin{array}{c}\mathrm{Mn} \\
(\mathrm{mg} / \mathrm{L})\end{array}$ & $\begin{array}{c}\mathrm{Si} \\
(\mathrm{mg} / \mathrm{L})\end{array}$ & $\begin{array}{c}\mathrm{S} \\
(\mathrm{mg} / \mathrm{L})\end{array}$ & $\begin{array}{c}\mathrm{SO}_{4} \\
(\mathrm{mg} / \mathrm{L})\end{array}$ & $\begin{array}{c}\mathrm{Cl} \\
(\mathrm{mg} / \mathrm{L})\end{array}$ & $\begin{array}{c}\mathrm{NO}_{3} \\
(\mathrm{mg} / \mathrm{L})\end{array}$ \\
\hline WEB-MWO2 & $25-$ Oct-04 & 32.0 & 4.83 & 3.45 & 3.90 & 0.13 & $<0.1$ & 2.81 & 7.71 & -- & $\overline{--}$ & -- \\
\hline MYR-MWO3 & 29-Nov-04 & 31.8 & 4.79 & 2.70 & 3.66 & $<0.1$ & $<0.1$ & 2.32 & 8.18 & -- & -- & -- \\
\hline MYR-MWO4 & 30-Dec-04 & 29.6 & 4.42 & 2.20 & 3.58 & 2.65 & $<0.1$ & 2.39 & 9.87 & -- & -- & -- \\
\hline MYR-MWO5 & 4-Feb-05 & 51.7 & 7.51 & 3.13 & 2.33 & -- & -- & 3.41 & -- & 16.0 & 8.41 & 3.57 \\
\hline MYR-MWO6 & 14-Mar-05 & 39.9 & 5.18 & -- & -- & -- & -- & 2.41 & 10.8 & -- & 22.4 & -- \\
\hline MYR-MWO7 & 14-Apr-05 & 37.0 & 5.05 & -- & -- & -- & -- & 2.33 & 10.8 & -- & 5.54 & -- \\
\hline BZK-MWO2 & 25-Oct-04 & 67.1 & 12.1 & 23.4 & $<0.1$ & 0.20 & $<0.1$ & 3.86 & 1.53 & -- & -- & -- \\
\hline BZK-MWO3 & 29-Nov-04 & 70.8 & 13.4 & 17.6 & 0.74 & 0.41 & $<0.1$ & 3.25 & 0.80 & -- & -- & -- \\
\hline BZK-MWO4 & 30-Dec-04 & 73.5 & 14.2 & 19.6 & 0.90 & 0.32 & $<0.1$ & 3.59 & 0.92 & -- & -- & -- \\
\hline BZK-MWO5 & 4-Feb-05 & 85.7 & 13.6 & 15.5 & 0.71 & -- & -- & 4.16 & -- & 3.30 & 32.7 & 0.54 \\
\hline BZK-MWO6 & 14-Mar-05 & 78.6 & 14.3 & -- & -- & -- & -- & 3.38 & 1.45 & -- & 38.8 & -- \\
\hline BZK-MWO7 & 14-Apr-05 & 76.8 & 13.8 & -- & -- & -- & -- & 3.40 & 1.33 & -- & 34.7 & -- \\
\hline YST-SPO1 & 17-Sep-04 & 2.75 & 1.56 & 0.49 & 0.83 & $<0.1$ & $<0.1$ & 2.23 & -- & 9.39 & 1.17 & 0.69 \\
\hline YST-SPO2 & 25-Oct-04 & 2.65 & 1.76 & 0.44 & 0.68 & $<0.1$ & $<0.1$ & 2.17 & 3.30 & -- & -- & -- \\
\hline HGH-SPO3 & 29-Nov-04 & 2.82 & 1.50 & 0.41 & 0.77 & $<0.1$ & 0.13 & 2.53 & 3.60 & -- & -- & -- \\
\hline HGH-SPO4 & 30-Dec-04 & 2.70 & 1.70 & 0.38 & 0.75 & $<0.1$ & 0.10 & 2.43 & 3.42 & -- & -- & -- \\
\hline HGH-SPO5 & 4-Feb-05 & 16.9 & 1.73 & 0.54 & 0.70 & -- & -- & 2.54 & -- & 10.00 & 0.93 & 0.47 \\
\hline HGH-SPO7 & 14-Apr-05 & 2.67 & 1.39 & -- & -- & -- & -- & 1.95 & 4.00 & -- & 1.27 & -- \\
\hline YST-MWO1 & 17-Sep-04 & 40.3 & 1.84 & 0.58 & 0.47 & 0.82 & $<0.1$ & 3.15 & -- & 8.23 & $<1.00$ & $<0.02$ \\
\hline YST-MWO2 & 25-Oct-04 & 41.9 & 2.06 & 0.51 & 0.62 & 3.81 & $<0.1$ & 3.45 & 1.89 & -- & -- & -- \\
\hline YST-MWO3 & 29-Nov-04 & 40.0 & 2.06 & 1.56 & 0.45 & 2.68 & $<0.1$ & 3.61 & 1.26 & -- & -- & -- \\
\hline YST-MWO4 & 30-Dec-04 & 40.7 & 2.21 & 0.93 & 0.96 & 0.20 & $<0.1$ & 4.29 & 2.04 & -- & -- & -- \\
\hline YST-DPO4 & 30-Dec-04 & 37.6 & 2.04 & 0.84 & 0.88 & 0.18 & $<0.1$ & 4.00 & 1.48 & -- & -- & -- \\
\hline YST-MWO5 & 4-Feb-05 & 54.8 & 2.10 & 0.68 & 0.47 & -- & -- & 4.50 & -- & 5.07 & 0.64 & 0.01 \\
\hline YST-MWO7 & 14-Apr-05 & 39.4 & 1.73 & -- & -- & -- & -- & 3.06 & 2.10 & -- & 0.81 & -- \\
\hline CSP-SPO1 & 17-Sep-04 & 48.3 & 5.55 & 1.11 & 0.73 & $<0.1$ & $<0.1$ & 3.83 & -- & 8.54 & 1.22 & 0.08 \\
\hline CSP-SPO2 & 25-Oct-04 & 57.2 & 7.11 & 1.08 & 0.55 & $<0.1$ & $<0.1$ & 3.99 & 1.75 & -- & -- & -- \\
\hline CSP-SPO3 & 29-Nov-04 & 50.8 & 6.31 & 0.99 & 2.55 & $<0.1$ & $<0.1$ & 3.70 & 1.58 & -- & -- & -- \\
\hline CSP-SPO4 & 30-Dec-04 & 51.5 & 6.52 & 0.97 & 0.54 & $<0.1$ & $<0.1$ & 3.88 & 1.58 & -- & -- & -- \\
\hline CSP-SPO5 & 4-Feb-05 & 78.6 & 8.54 & 1.39 & 0.64 & -- & -- & 5.81 & -- & 5.17 & 1.30 & 0.05 \\
\hline CSP-SPO6 & 14-Mar-05 & 60.8 & 6.98 & -- & -- & -- & -- & 4.13 & 2.13 & -- & 1.48 & -- \\
\hline CSP-SPO7 & 14-Apr-05 & 60.4 & 7.03 & -- & -- & -- & -- & 4.09 & 2.38 & -- & 1.37 & -- \\
\hline
\end{tabular}

-- Indicates not measured.

$<$ Indicates below detection limit, followed by the detection limit. 
Table A-7: Mean and coefficient of variation for selected parameters at study sites. (Page 1 of 2)

\begin{tabular}{|c|c|c|c|c|c|c|c|c|c|c|c|c|c|c|c|}
\hline Site & $\mathrm{pH}$ & $\mathrm{T}$ & SC & $\mathrm{HCO}_{3}$ & $\mathrm{SO}_{4}$ & $\mathrm{Na}$ & $\mathrm{Cl}$ & $\mathrm{Si}$ & $\mathrm{Ca}$ & $\mathrm{Mg}$ & $\mathrm{CaCO}_{3}$ & $\mathrm{Ca} / \mathrm{Mg}$ & $\mathrm{SI}_{\mathrm{C}}$ & $\mathrm{SI}_{\mathrm{D}}$ & En $\mathrm{P}_{\mathrm{CO} 2}$ \\
\hline \multicolumn{16}{|l|}{ LDY } \\
\hline Mean & 6.70 & 22.2 & 293 & 151 & 14.1 & 4.30 & 3.01 & 4.49 & 48.4 & 4.81 & 141 & 6.11 & -0.89 & -2.47 & 100 \\
\hline COV & 3 & 1 & 10 & 11 & 13 & -- & -- & 8 & 10 & 9 & 10 & 7 & 23 & 17 & 42 \\
\hline \multicolumn{16}{|l|}{ STR* $^{*}$} \\
\hline COV & 3 & 10 & 6 & 4 & 18 & -- & -- & 3 & 6 & 8 & 5 & 8 & 140 & 243 & 50 \\
\hline \multicolumn{16}{|l|}{ MTN } \\
\hline Mean & 4.80 & 11.9 & 54 & 6 & 9.95 & 0.98 & 1.68 & 2.73 & 3.29 & 2.29 & 17.6 & 0.87 & -5.74 & -11.5 & 267 \\
\hline COV & 6 & 7 & 13 & 208 & 16 & -- & -- & 10 & 8 & 11 & 9 & 5 & 11 & 11 & 118 \\
\hline \multicolumn{16}{|l|}{ NEY } \\
\hline Mean & 6.83 & 11.3 & 252 & 144 & 6.86 & 2.17 & 4.78 & 3.06 & 38.5 & 6.75 & 124 & 3.42 & -1.07 & -2.74 & 61 \\
\hline COV & 4 & 7 & 28 & 31 & 21 & -- & -- & 10 & 26 & 20 & 25 & 9 & 41 & 31 & 51 \\
\hline \multicolumn{16}{|l|}{ WEB } \\
\hline Mean & 7.13 & 12.3 & 361 & 240 & 4.07 & 2.63 & 6.22 & 3.75 & 65.3 & 10.2 & 205 & 3.91 & -0.31 & -1.26 & 50 \\
\hline COV & 2 & 7 & 11 & 7 & 31 & -- & -- & 11 & 9 & 13 & 9 & 8 & 41 & 23 & 37 \\
\hline
\end{tabular}

Asterisks denote wells; $\mathrm{HCO}$, SO4, $\mathrm{Na}, \mathrm{Cl}, \mathrm{Si}, \mathrm{Ca}, \mathrm{Mg}$, and hardness as $\mathrm{CaCO}$, all given in $\mathrm{mg} / \mathrm{L}$; -- Indicates that COV was not calculated;

En $\mathrm{PCO} 2$ represents enhanced $\mathrm{PCO} 2 ; \mathrm{Ca} / \mathrm{Mg}$ is a molar ratio; $\mathrm{T}$ given in ${ }^{\circ} \mathrm{C}$. 
Table A-7: Mean and coefficient of variation for selected parameters at study sites. (Page 2 of 2 )

\begin{tabular}{|c|c|c|c|c|c|c|c|c|c|c|c|c|c|c|c|}
\hline Site & $\mathrm{pH}$ & $\mathrm{T}$ & SC & $\mathrm{HCO}_{3}$ & $\mathrm{SO}_{4}$ & $\mathrm{Na}$ & $\mathrm{Cl}$ & Si & $\mathrm{Ca}$ & $\mathrm{Mg}$ & $\mathrm{CaCO}_{3}$ & $\mathrm{Ca} / \mathrm{Mg}$ & $\mathrm{SI}_{\mathrm{C}}$ & $S I_{D}$ & En $P_{\mathrm{CO} 2}$ \\
\hline \multicolumn{16}{|l|}{ MYR* $^{*}$} \\
\hline Mean & 5.98 & 9.9 & 264 & 88 & 26.3 & 2.87 & 12. & -1 & 37.0 & 5.30 & 114 & 4.23 & -2.18 & -5.17 & 240 \\
\hline COV & 2 & 34 & 7 & 40 & 22 & -- & -- & טו & 20 & 19 & 20 & 6 & 13 & 13 & 30 \\
\hline \multicolumn{16}{|l|}{$\mathrm{BZK}^{*}$} \\
\hline Mean & 7.17 & 9.2 & 506 & 263 & 3.56 & 19.0 & 35.4 & 3.61 & 75.4 & 13.6 & 244 & 3.37 & -0.24 & -1.10 & 46 \\
\hline COV & 2 & 41 & 6 & 9 & 23 & -- & -- & 9 & 8 & 5 & 7 & 7 & 57 & 28 & 24 \\
\hline \multicolumn{16}{|l|}{$\mathrm{HGH}$} \\
\hline Mean & 4.59 & 12.0 & 43 & 2 & 10.4 & 0.45 & 1.12 & 2.31 & 5.08 & 1.61 & 19.3 & 1.86 & -5.79 & -11.8 & 578 \\
\hline $\mathrm{COV}$ & 9 & 2 & 14 & 2 & 8 & -- & -- & 9 & 104 & 8 & 70 & 98 & 9 & 8 & 127 \\
\hline \multicolumn{16}{|l|}{$\mathrm{YST}^{*}$} \\
\hline Mean & 6.54 & 14.6 & 203 & 118 & 5.86 & 0.85 & 0.73 & 3.68 & 42.9 & 2.00 & 115 & 13.0 & -1.31 & -3.75 & 105 \\
\hline COV & 3 & 15 & 11 & 19 & 23 & -- & -- & 15 & 13 & 8 & 12 & 12 & 14 & 11 & 59 \\
\hline \multicolumn{16}{|l|}{ CSP } \\
\hline Mean & 6.93 & 12.1 & 312 & 210 & 5.99 & 1.11 & 1.34 & 4.20 & 58.2 & 6.86 & 174 & 5.13 & -0.61 & -1.98 & 71 \\
\hline COV & 3 & 5 & 8 & 13 & 22 & -- & -- & 16 & 16 & 12 & 16 & 5 & 31 & 19 & 43 \\
\hline
\end{tabular}

Asterisks denote wells; $\mathrm{HCO}$, $\mathrm{SO} 4, \mathrm{Na}, \mathrm{Cl}, \mathrm{Si}, \mathrm{Ca}, \mathrm{Mg}$, and hardness as $\mathrm{CaCO}$, all given in $\mathrm{mg} / \mathrm{L}$; -- Indicates that COV was not calculated;

En $\mathrm{PCO} 2$ represents enhanced $\mathrm{PCO} 2 ; \mathrm{Ca} / \mathrm{Mg}$ is a molar ratio; $\mathrm{T}$ given in ${ }^{\circ} \mathrm{C}$. 
Table A-8: Derived chemical data. (Page 1 of 2)

\begin{tabular}{|c|c|c|c|c|c|c|c|c|c|c|c|c|}
\hline Sample ID & Sample Date & $\begin{array}{c}\mathrm{Ca} / \mathrm{Mg} \\
(\mathrm{M})\end{array}$ & $\mathrm{SI}_{\mathrm{C}}$ & $\mathrm{SI}_{\text {Chal }}$ & $\mathrm{SI}_{\mathrm{D}}$ dis & $\mathrm{SI}_{\mathrm{D}}$ & $\mathrm{Sl}_{\mathrm{Q}}$ & $\begin{array}{l}\mathrm{P}_{\mathrm{CO} 2} \\
\text { (atm) }\end{array}$ & $\begin{array}{c}\log P_{\mathrm{CO} 2} \\
(\mathrm{~atm})\end{array}$ & Enhanced $\mathrm{P}_{\mathrm{CO} 2}$ & $\begin{array}{c}\text { Ionic } \\
\text { Strength }\end{array}$ & $\begin{array}{l}\text { CBE } \\
(\%) \\
\end{array}$ \\
\hline LDY-SP01 & 17-Sep-04 & 6.21 & -0.70 & -0.19 & -2.65 & -2.09 & 0.26 & 0.023 & -1.63 & 74.0 & 4.70E-03 & 5.99 \\
\hline LDY-SP02 & 25-Oct-04 & 5.92 & -0.64 & -0.21 & -2.52 & -1.96 & 0.25 & 0.023 & -1.63 & 73.5 & 4.50E-03 & 5.96 \\
\hline LDY-SP03 & 29-Nov-04 & 5.91 & -0.68 & -0.16 & -2.61 & -2.05 & 0.30 & 0.017 & -1.77 & 54.3 & 4.60E-03 & 13.83 \\
\hline LDY-SP04 & 30-Dec-04 & 5.40 & -0.90 & -0.28 & -3.01 & -2.45 & 0.17 & 0.018 & -1.75 & 56.5 & 3.60E-03 & 2.58 \\
\hline LDY-SP05 & 4-Feb-05 & 7.02 & -1.09 & -0.21 & -3.49 & -2.93 & 0.25 & 0.044 & -1.36 & 138 & 4.30E-03 & 2.65 \\
\hline LDY-SP06 & 14-Mar-05 & 6.10 & -1.07 & -0.22 & -3.40 & -2.83 & 0.24 & 0.049 & -1.31 & 154 & 4.10E-03 & 2.31 \\
\hline LDY-SP07 & 14-Apr-05 & 6.25 & -1.15 & -0.23 & -3.56 & -3.00 & 0.22 & 0.047 & -1.33 & 147 & $3.90 \mathrm{E}-03$ & 8.05 \\
\hline STR-MW02 & $25-O c t-04$ & 1.92 & 0.17 & -0.21 & -0.57 & 0.03 & 0.26 & 0.026 & -1.58 & 83.2 & $1.32 \mathrm{E}-02$ & 7.50 \\
\hline STR-MW03 & 29-Nov-04 & 2.18 & 0.26 & -0.19 & -0.49 & 0.12 & 0.28 & 0.016 & -1.79 & 51.4 & 1.18E-02 & 7.69 \\
\hline STR-MW04 & 30-Dec-04 & 1.86 & 0.25 & -0.16 & -0.44 & 0.17 & 0.31 & 0.017 & -1.77 & 54.2 & 1.26E-02 & 8.54 \\
\hline STR-MW06 & 14-Mar-05 & 2.07 & -0.04 & -0.23 & -1.00 & -0.41 & 0.24 & 0.053 & -1.27 & 169 & 1.35E-02 & 2.22 \\
\hline STR-MW07 & 14-Apr-05 & 1.75 & -0.10 & -0.24 & -1.07 & -0.47 & 0.23 & 0.051 & -1.29 & 162 & 1.26E-02 & 1.71 \\
\hline MTN-SP01 & 17-Sep-04 & 0.94 & -4.39 & -0.30 & -9.38 & -8.78 & 0.17 & 0.316 & -0.50 & 1000 & 9.00E-04 & 34.45 \\
\hline MTN-SP02 & 25-Oct-04 & 0.89 & -6.23 & -0.37 & -13.06 & -12.46 & 0.10 & 0.003 & -2.48 & 10.6 & 5.00E-04 & 45.76 \\
\hline MTN-SP03 & 29-Nov-04 & 0.81 & -5.78 & -0.32 & -12.13 & -11.53 & 0.15 & 0.009 & -2.04 & 29.1 & 6.00E-04 & 31.69 \\
\hline MTN-SP04 & 30-Dec-04 & 0.83 & -5.23 & -0.24 & -11.04 & -10.44 & 0.23 & 0.047 & -1.32 & 150 & 7.00E-04 & 25.27 \\
\hline MTN-SP05 & 4-Feb-05 & 0.83 & -6.22 & -0.25 & -13.04 & -12.43 & 0.22 & 0.072 & -1.14 & 229 & 6.00E-04 & 19.46 \\
\hline MTN-SP06 & 14-Mar-05 & 0.91 & -6.14 & -0.33 & -12.93 & -12.32 & 0.14 & 0.045 & -1.35 & 142 & 4.00E-04 & 64.33 \\
\hline MTN-SP07 & 14-Apr-05 & 0.90 & -6.20 & -0.32 & -13.03 & -12.42 & 0.15 & 0.098 & -1.01 & 311 & 4.00E-04 & 59.84 \\
\hline NEY-SP01 & 17-Sep-04 & 3.63 & -0.43 & -0.21 & -2.08 & -1.48 & 0.26 & 0.011 & -1.97 & 34.1 & 5.30E-03 & 5.12 \\
\hline NEY-SP02 & 25-Oct-04 & 3.33 & -0.54 & -0.32 & -2.27 & -1.66 & 0.15 & 0.010 & -2.01 & 30.7 & 4.20E-03 & 5.01 \\
\hline NEY-SP03 & 29-Nov-04 & 2.85 & -1.69 & -0.29 & -4.49 & -3.89 & 0.18 & 0.015 & -1.82 & 47.8 & $2.30 \mathrm{E}-03$ & 3.75 \\
\hline NEY-SP04 & 30-Dec-04 & 3.20 & -1.01 & -0.25 & -3.20 & -2.59 & 0.22 & 0.010 & -1.99 & 32.6 & 3.30E-03 & 3.81 \\
\hline NEY-SP05 & 5-Feb-05 & 3.91 & -0.99 & -0.17 & -3.26 & -2.65 & 0.30 & 0.037 & -1.43 & 116 & 4.70E-03 & 11.54 \\
\hline NEY-SP06 & 14-Mar-05 & 3.59 & -1.29 & -0.26 & -3.84 & -3.23 & 0.22 & 0.024 & -1.63 & 74.7 & 3.50E-03 & 5.86 \\
\hline NEY-SP07 & 14-Apr-05 & 3.44 & -1.52 & -0.25 & -4.26 & -3.65 & 0.22 & 0.030 & -1.53 & 94.3 & 3.20E-03 & 7.37 \\
\hline WEB-SP01 & 17-Sep-04 & 4.03 & -0.31 & -0.23 & -1.86 & -1.26 & 0.24 & 0.013 & -1.88 & 41.8 & $5.80 \mathrm{E}-03$ & 0.98 \\
\hline WEB-SP02 & 25-Oct-04 & 3.57 & -0.08 & -0.11 & -1.34 & -0.74 & 0.36 & 0.008 & -2.07 & 26.7 & 6.60E-03 & 16.19 \\
\hline WEB-SP03 & 29-Nov-04 & 3.60 & -0.22 & -0.20 & -1.64 & -1.04 & 0.27 & 0.012 & -1.94 & 36.5 & 5.80E-03 & 0.64 \\
\hline WEB-SP04 & 30-Dec-04 & 3.51 & -0.26 & -0.17 & -1.75 & -1.14 & 0.30 & 0.010 & -1.99 & 32.7 & 5.70E-03 & 0.23 \\
\hline WEB-SP05 & 5-Feb-05 & 4.06 & -0.36 & -0.10 & -1.99 & -1.38 & 0.37 & 0.023 & -1.64 & 71.9 & 6.70E-03 & 1.10 \\
\hline WEB-SP06 & 14-Mar-05 & 4.10 & -0.47 & -0.21 & -2.21 & -1.61 & 0.26 & 0.022 & -1.66 & 69.6 & 5.90E-03 & 2.01 \\
\hline WEB-SP07 & 14-Apr-05 & 4.48 & -0.46 & -0.20 & -2.23 & -1.63 & 0.27 & 0.023 & -1.64 & 72.3 & 5.90E-03 & 5.49 \\
\hline
\end{tabular}


Table A-8: Derived chemical data. (Page 2 of 2)

\begin{tabular}{|c|c|c|c|c|c|c|c|c|c|c|c|c|}
\hline Sample ID & Sample Date & $\begin{array}{c}\mathrm{Ca} / \mathrm{Mg} \\
(\mathrm{M})\end{array}$ & $\mathrm{SI}_{\mathrm{C}}$ & $\mathrm{SI}_{\text {Chal }}$ & $\mathrm{SI}_{\mathrm{D}}$ dis & $\mathrm{SI}_{\mathrm{D}}$ & $\mathrm{Sl}_{\mathrm{Q}}$ & $\begin{array}{l}\mathrm{P}_{\mathrm{CO} 2} \\
\text { (atm) }\end{array}$ & $\begin{array}{c}\log P_{\mathrm{CO} 2} \\
\text { (atm) }\end{array}$ & Enhanced $\mathrm{P}_{\mathrm{CO} 2}$ & $\begin{array}{c}\text { Ionic } \\
\text { Strength }\end{array}$ & $\begin{array}{c}\text { CBE } \\
(\%)\end{array}$ \\
\hline MYR-MW02 & $25-$ Oct-04 & 4.02 & -2.05 & -0.33 & -5.30 & -4.71 & 0.14 & 0.059 & -1.23 & 186 & $3.10 \mathrm{E}-03$ & 11.69 \\
\hline MYR-MW03 & 29-Nov-04 & 4.02 & -2.29 & -0.37 & -5.85 & -5.24 & 0.10 & 0.098 & -1.01 & 310 & $3.20 E-03$ & 6.79 \\
\hline MYR-MW04 & 30-Dec-04 & 4.06 & -2.52 & -0.31 & -6.39 & -5.76 & 0.17 & 0.034 & -1.47 & 108 & 2.90E-03 & 23.63 \\
\hline MYR-MW05 & 5-Feb-05 & 4.17 & -1.60 & -0.14 & -4.59 & -3.96 & 0.34 & 0.081 & -1.09 & 255 & 4.90E-03 & 2.47 \\
\hline MYR-MW06 & 14-Mar-05 & 4.67 & -2.34 & -0.28 & -6.13 & -5.50 & 0.21 & 0.099 & -1.01 & 312 & $3.40 \mathrm{E}-03$ & 8.92 \\
\hline MYR-MW07 & 14-Apr-05 & 4.44 & -2.27 & -0.38 & -0.38 & -5.85 & 0.09 & 0.086 & -1.07 & 271 & 2.90E-03 & 25.46 \\
\hline BZK-MW02 & 25-Oct-04 & 3.37 & -0.06 & -0.18 & -1.27 & -0.67 & 0.29 & 0.011 & -1.96 & 34.5 & $7.00 \mathrm{E}-03$ & 9.90 \\
\hline BZK-MW03 & 29-Nov-04 & 3.20 & -0.10 & -0.20 & -1.42 & -0.81 & 0.28 & 0.009 & -2.02 & 30.0 & 7.00E-03 & 12.48 \\
\hline BZK-MW04 & 30-Dec-04 & 3.13 & -0.33 & -0.11 & -1.93 & -1.30 & 0.37 & 0.013 & -1.89 & 41.1 & $7.20 \mathrm{E}-03$ & 17.04 \\
\hline BZK-MW05 & 5-Feb-05 & 3.83 & -0.19 & -0.06 & -1.73 & -1.10 & 0.42 & 0.018 & -1.75 & 56.1 & 8.60E-03 & 0.23 \\
\hline BZK-MW06 & 14-Mar-05 & 3.33 & -0.45 & -0.11 & -2.25 & -1.61 & 0.38 & 0.018 & -1.74 & 57.2 & 7.60E-03 & 2.36 \\
\hline BZK-MW07 & 14-Apr-05 & 3.38 & -0.29 & -0.24 & -1.72 & -1.12 & 0.23 & 0.017 & -1.76 & 55.1 & 7.30E-03 & 0.91 \\
\hline YST-SP01 & 17-Sep-04 & 1.07 & -4.96 & -0.39 & -10.60 & -10.00 & 0.08 & 0.113 & -0.95 & 358 & 6.00E-04 & 17.22 \\
\hline YST-SP02 & 25-Oct-04 & 0.91 & -5.90 & -0.41 & -12.41 & -11.81 & 0.07 & 0.009 & -2.04 & 29.1 & 5.00E-04 & 17.73 \\
\hline HGH-SP03 & 29-Nov-04 & 1.14 & -6.25 & -0.34 & -13.22 & -12.61 & 0.13 & 0.038 & -1.42 & 121 & 5.00E-04 & 14.30 \\
\hline HGH-SP04 & 30-Dec-04 & 0.96 & -5.84 & -0.36 & -12.33 & -11.72 & 0.12 & 0.049 & -1.31 & 156 & 5.00E-04 & 11.73 \\
\hline HGH-SP05 & 5-Feb-05 & 5.92 & -5.51 & -0.34 & -12.45 & -11.85 & 0.14 & 0.271 & -0.57 & 858 & 1.30E-03 & 56.70 \\
\hline HGH-SP07 & 13-Apr-05 & 1.16 & -6.28 & -0.45 & -13.30 & -12.69 & 0.02 & 0.615 & -0.21 & 1946 & 4.00E-04 & 43.06 \\
\hline YST-MW01 & 17-Sep-04 & 13.28 & -1.27 & -0.30 & -4.24 & -3.66 & 0.17 & 0.028 & -1.55 & 89.0 & 3.30E-03 & 3.29 \\
\hline YST-MW02 & 25-Oct-04 & 12.33 & -1.05 & -0.27 & -3.75 & -3.17 & 0.20 & 0.019 & -1.73 & 58.7 & $3.40 \mathrm{E}-03$ & 8.31 \\
\hline YST-MW03 & 29-Nov-04 & 11.78 & -1.12 & -0.24 & -3.88 & -3.30 & 0.22 & 0.023 & -1.65 & 71.4 & 3.30E-03 & 5.69 \\
\hline YST-MW04 & 30-Dec-04 & 11.17 & -1.45 & -0.12 & -4.58 & -3.98 & 0.35 & 0.021 & -1.68 & 65.6 & 3.00E-03 & 19.05 \\
\hline YST-MW05 & 5-Feb-05 & 15.83 & -1.41 & -0.09 & -4.67 & -4.06 & 0.38 & 0.076 & -1.12 & 239 & 4.30E-03 & 3.60 \\
\hline YST-MW07 & 13-Apr-05 & 13.81 & -1.57 & -0.25 & -4.95 & -4.34 & 0.22 & 0.034 & -1.46 & 109 & 2.90E-03 & 11.08 \\
\hline CSP-SP01 & 17-Sep-04 & 5.27 & -0.70 & -0.18 & -2.75 & -2.16 & 0.29 & 0.027 & -1.57 & 86.0 & 4.80E-03 & 14.70 \\
\hline CSP-SP02 & 25-Oct-04 & 4.88 & -0.39 & -0.14 & -2.12 & -1.52 & 0.33 & 0.011 & -1.95 & 35.7 & 5.10E-03 & 1.54 \\
\hline CSP-SP03 & 29-Nov-04 & 4.89 & -0.51 & -0.17 & -2.36 & -1.76 & 0.30 & 0.012 & -1.92 & 38.1 & 4.70E-03 & 0.98 \\
\hline CSP-SP04 & 30-Dec-04 & 4.79 & -0.51 & -0.15 & -2.37 & -1.77 & 0.32 & 0.012 & -1.91 & 38.8 & 4.70E-03 & 0.74 \\
\hline CSP-SP05 & 5-Feb-05 & 5.58 & -0.45 & 0.03 & -2.32 & -1.71 & 0.50 & 0.030 & -1.53 & 94.1 & 6.80E-03 & 1.48 \\
\hline CSP-SP06 & 14-Mar-05 & 5.28 & -0.96 & -0.12 & -3.32 & -2.71 & 0.35 & 0.037 & -1.43 & 117 & 5.00E-03 & 8.83 \\
\hline CSP-SP07 & 14-Apr-05 & 5.21 & -0.72 & -0.13 & -2.83 & -2.23 & 0.35 & 0.028 & -1.55 & 89.9 & 5.30E-03 & 1.23 \\
\hline
\end{tabular}

